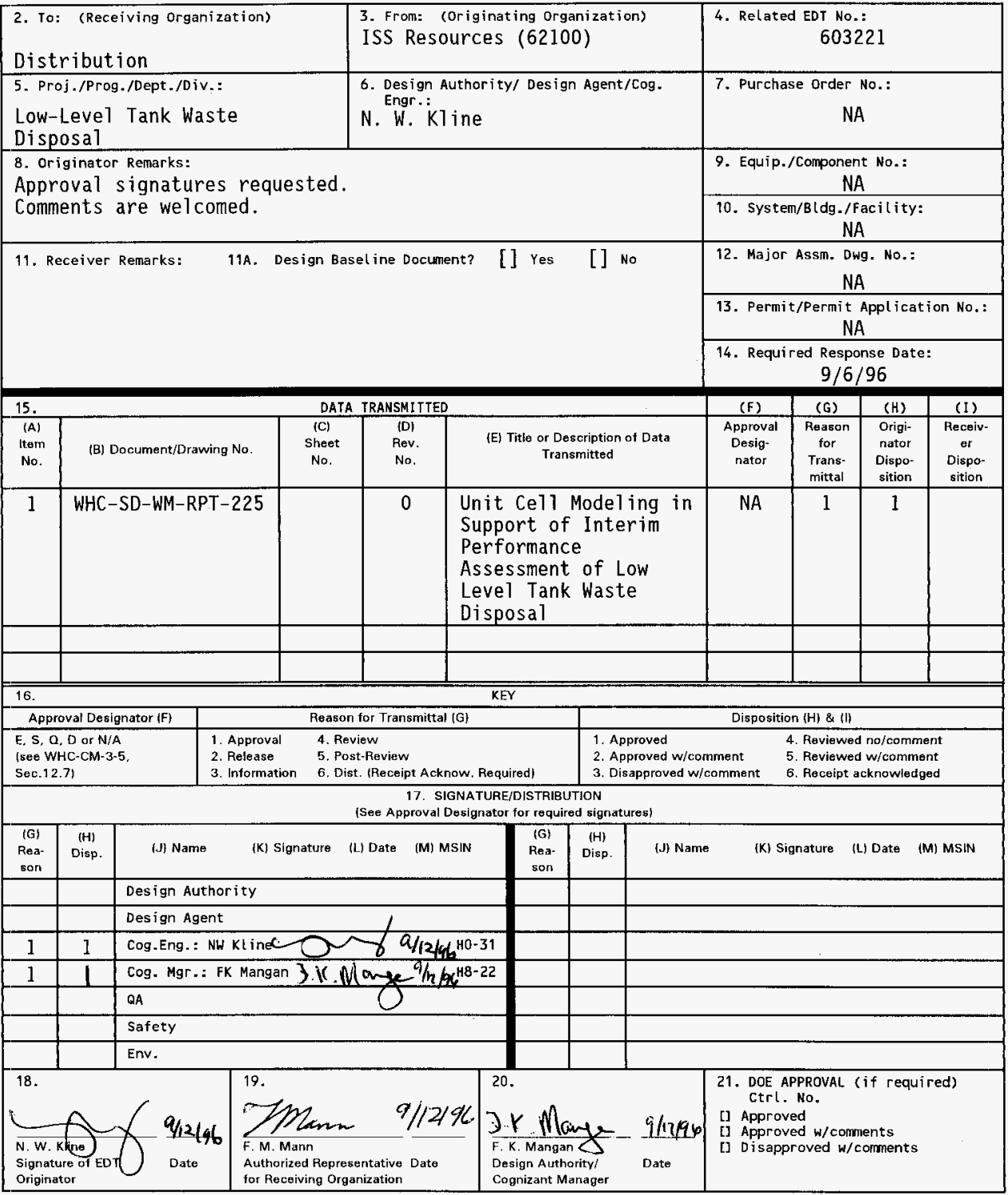




\section{Unit Cell Modeling in Support of Interim Performance Assessment for Low Level Tank Waste Disposal}

Niall W. K1 ine

BCS Richland, Inc., Richland, WA 99352

U.S. Department of Energy Contract DE-AC06-87RL10930

\begin{tabular}{|c|c|}
\hline $\begin{array}{l}\text { EDT/ECN: } \\
\text { Org Code: } \\
\text { B\&R Code: }\end{array}$ & $\begin{array}{l}618552 \\
8 M 740 \\
\text { EW3130010 }\end{array}$ \\
\hline
\end{tabular}

Key Words: Performance Assessment

Low Level Tank Waste Disposal

Flow and Transport Modeling

Abstract: A unit cell model is used to simulate the base analysis case and related sensitivity cases for the interim performance assessment of low level tank waste disposal. Simulation case results are summarized in terms of fractional contaminant release rates to the vadose zone and to the water table at the unconfined aquifer. Results suggest that the crushed glass water conditioning layer at the top of the facility and the chemical retardation pad at the bottom of the facility can be important combnents of the facility. Results also suggest that the release rates to the water table are dominated by the release rate from the waste form.

TRADEMARK DISCLAIMER. Reference herein to any specific comercial product, process, or service by trade name, trademark, manufacturer, or otherwise, does not necessarily constitute or imply its endorsement, recommendation, or favoring by the United States Government or any agency thereof or its contractors or subcontractors.

Printed in the United States of America. To obtain copies of this document, contact: WHC/BCS Document Control Services, P.0. Box 1970, Mailstop H6-08, Richland WA 99352, Phone (509) 372-2420; Fax (509) 376-4989.
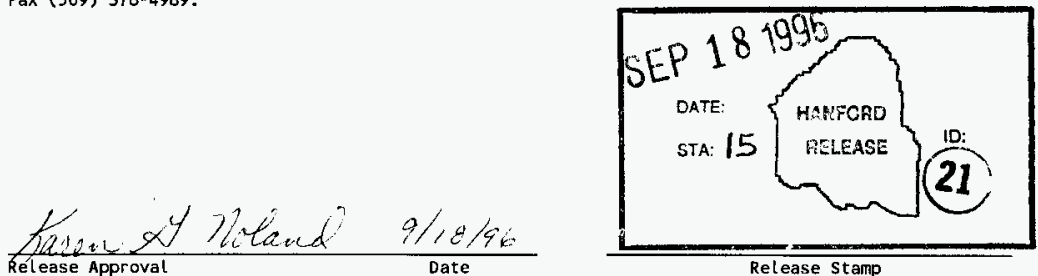
WHC-SD-WM-RPT-225 ReV . 0

\section{UNIT CELL MODELING IN SUPPORT OF INTERIM PERFORMANCE ASSESSMENT FOR LOW LEVEL TANK WASTE DISPOSAL}

Prepared by:

Reviewed by:

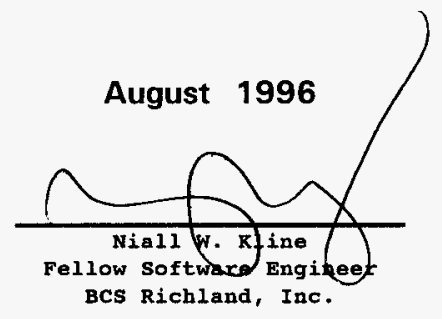

Date: $8 / 22 / 96$

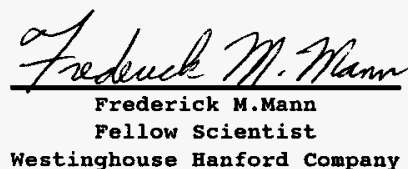

Date: $8 / 27 / \mathcal{X}$ 
WHC-SD-WM-RPT-225, Rev. 0

\section{CONTENTS}

Page

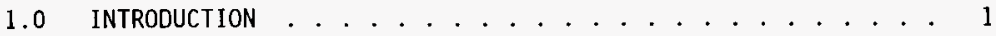

1.1 Background .................... 1

1.2 Purpose and Scope.................. 1

2.0 BASE CASE MODEL . . . . . . . . . . . . . . . . . . 1

2.1 Model Construction .................. 1

2.2 Base Case Modifications ............... . 3

2.3 Summary of Base Case Results . . . . . . . . . . . 6

3.0 SENSITIVITY CASES . . . . . . . . . . . . . . . 10

3.1 Sensitivity Case 1.............. 10

3.2 Sensitivity Case 2 .............. 10

3.3 Sensitivity Case 3 .............. . . . 10

3.4 Sensitivity Case 4 ................ . . 11

3.5 Sensitivity Case 5 ............... 11

3.6 Sensitivity Case 6 .............. . 12

3.7 Sensitivity Case 7 . . . . . . . . . . . . 13

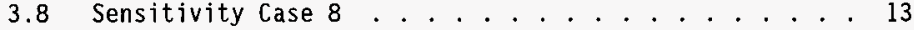

3.9 Sensitivity Case 9............... 13

3.10 Sensitivity Case 10 . . . . . . . . . . . . . . 14

3.11 Sensitivity Case 11 . . . . . . . . . . . . . . . . 14

3.12 Sensitivity Case 12 . . . . . . . . . . . . . 14

3.13 Sensitivity Case 13 . . . . . . . . . . . . . . . 15

3.14 Sensitivity Case 14 . . . . . . . . . . . . . 15

3.15 Sensitivity Case 15 . . . . . . . . . . . . . . 15

3.16 Sensitivity Case 16 .............. . 16

3.17 Sensitivity Case 17 ................ 16

3.18 Sensitivity Case 18 . . . . . . . . . . . . . 16

3.19 Sensitivity Case 19 . . . . . . . . . . . . . . . . . 16

3.20 Sensitivity Case 20... . . . . . . . . . . . . 17

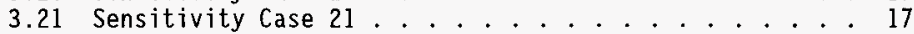

3.22 Sensitivity Case 22 . . . . . . . . . . . . 18

4.0 SUMMARY AND CONCLUSIONS .................... 19

5.0 REFERENCES ....................... . . . 23

APPENDIX A. Nomenclature . . . . . . . . . . . . . . A-1

APPENDIX B. Referenced Correspondence . . . . . . . . . . . B-1

APPENDIX C. Computer Model File Naming and Storage . . . . . . . . C-1

APPENDIX D. Mode1 Input for Sensitivity Case 22 . . . . . . . D-1 


\section{LIST OF TABLES}

Page

1. Summary of Hydraulic Parameter Values . . . . . . . . . . . . . . 2

2. Simulated Steady State Water Contents in the Unit Cell Model . . . 7

3. Correspondence of Contaminant Bins and $K_{d}$ Bins . . . . . . . . . . . 9

4. Summary of Simulated Releases to the Water Table for Unretarded Species from the Base Case and Sensitivity Cases $1-21$.................... 22

5. Summary of Simulated Releases to the Water Table for Sensitivity Case 22 (sensb22) . . . . . . . . . . . . . . . 23

\section{LIST OF FIGURES}

1. Schematic Diagram of Base Case Unit Cell Model . . . . . . . . . . 25

2. Schematic Diagram of Modified Unit Cel1 Mode1 . . . . . . . . . 26

3. Base Case Steady State Flow Field . . . . . . . . . . . . . . . . 27

4. Mesh Plot with Streamlines . . . . . . . . . . . . . 28

5. Base Case Time History of Instantaneous Fluid Flux . . . . . . . . 29

6. Computation of Fractional Release Rate from the Vault Floor ...................... . . 30

7. Simulated Fractional Release Rates for the Base Case . . . . . . . 31

8. Simulated Fractional Release Rates for Sensitivity

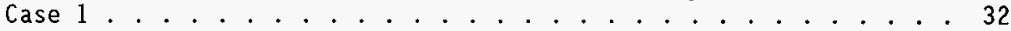

9. Simulated Fractional Release Rates for Sensitivity

Case 2..................... . . . . 33

10. Simulated Fractional Release Rates for Sensitivity

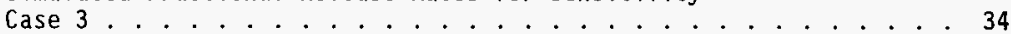

11. Simulated Fractional Release Rates for Sensitivity

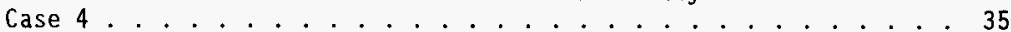

12a. Simulated Fractional Release Rates for Sensitivity

Case 5................... . . . . . . . . . . . . . . . .

12b. Simulated Fractional Release Rates for Sensitivity

Case 5 with Extended Preconditioning . . . . . . . . . . . 37 


\section{LIST OF FIGURES (Cont' d)}

13. Simulated Fractional Release Rates for Sensitivity

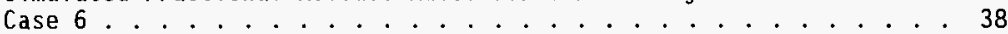

14. Simulated Fractional Release Rates for Sensitivity

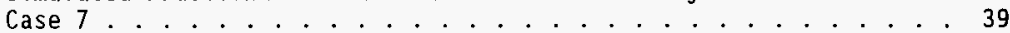

15. Simulated Fractional Release Rates for Sensitivity

Case 8.................... . . . 40 40

16. Simulated Fractional Release Rates for Sensitivity Case 9..................... . . 4 41

17. Simulated Fractional Release Rates for Sensitivity Case 10 . . . . . . . . . . . . . . . . 42

18. Simulated Fractional Release Rates for Sensitivity

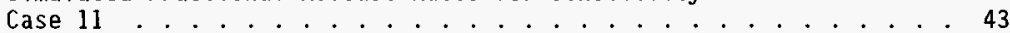

19. Simulated Fractional Release Rates for Sensitivity Case 12

20. Simulated Fractional Release Rates for Sensitivity Case 13 .................... . . . 45

21. Simulated Fractional Release Rates for Sensitivity Case 14 . . . . . . . . . . . . . . . . . . . 46

22. Simulated Fractional Release Rates for Sensitivity

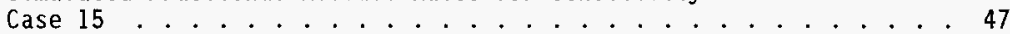

23. Simulated Fractional Release Rates for Sensitivity

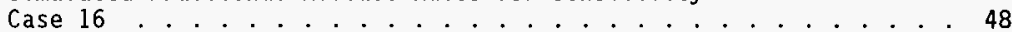

24. Simulated Fractional Release Rates for Sensitivity Case 17 . . . . . . . . . . . . . . . . . 49

25. Simulated Fractional Release Rates for Sensitivity

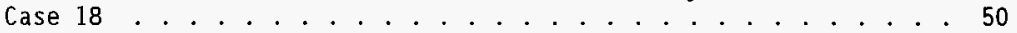

26. Simulated Fractional Release Rates for Sensitivity Case 19 ..................... . . 51

27a. Simulated Fractional Release Rates for Sensitivity Case 20

27b. Extended Simulated Fractional Release Rates for Sensitivity Case 20 . . . . . . . . . . . . . . . . 53

28. Comparison of Analytic Source Terms . . . . . . . . . . . . . 54

29. Simulated Fractional Release Rates for Sensitivity Case 21 
WHC-SD-WM-RPT-225, Rev. 0

LIST OF FIGURES (Cont'd)

30. Source Term for Sensitivity Case 22 . . . . . . . . . . . . . 56

31. Simulated Fractional Release Rates for Sensitivity Case 22 . . . . . . . . . . . . . . . 57 
WHC-SD-WM-RPT-225, Rev. 0

\section{ACKNOWLEDGMENTS}

The author wishes to thank Pete McGrail and Yueting Chen of the Pacific Northwest National Laboratory for providing the results of the AREST-CT

simulation of the low-level tank waste source term. The author also wishes to thank Dolores (Dee) Lessor of Westinghouse Hanford Company for her untiring support in postprocessing simulation output files and preparation of the figures contained in this report.

\section{TRADEMARK ACKNOWLEDGEMENTS}

IBM and RISC system/6000 are registered trademarks of International Business Machines Corporation, Armonk, New York.

PORFLOW and PORFLO are trademarks of Analytic and Computational Research, Inc., Bel Air, California.

Silicon Graphics is a trademark of Silicon Graphics, Inc.

TECPLOT is a trademark of Amtec Engineering, Inc., Bellevue, Washington.

UNIX is a registered trademark of AT\&T. 


\subsection{INTRODUCTION}

\subsection{BACKGROUND}

In 1995 a unit cell model of a low-level tank waste disposal facility was developed by Kline 1995 for use in updating a report on disposal system design options (Mann et a1. 1995a). The unit cell modeling approach proved to be efficient in that results from cases to which it was applicable could be obtained within a few minutes of computer time. Comparable run times from a full facility model were generally measured most conveniently in days. The unit cell model is generally applicable to investigations of effects of variations in material properties and boundary conditions. Because of the unit cell model compactness, it can also be useful for determining effects of

some geometric variations (e.g., layer thicknesses and depth from 1 and surface to the water table). Due to the general economy and utility of the unit cell modeling approach and because of the recent success in applying the unit cell modeling approach to low-level tank waste disposal system design options, the unit cell modeling approach is being further utilized in support of the Interim Performance Assessment (IPA) for low-7evel tank waste disposal.

\subsection{PURPOSE AND SCOPE}

The purpose of this report is to describe unit cell modeling of the lowTevel tank waste disposal Interim Performance Assessment Base Analysis Case defined by Mann et a1. 1995b. A1though the subject unit cell mode1 has been developed in accordance with the IPA Base Analysis Case (referred to hereafter as the "base case"), a few assumptions were necessary in the inital model construction phase. Preliminary computer runs of the base case with the unit cell model gradually yielded insights that led to modifications of the unit cell model. The unit cell model modifications were driven by attempts to verify/confirm reasonableness of results from the preliminary runs. The scope of this unit cell modeling description includes assumptions made in the initial model setup, modifications necessitated by results of preliminary runs, a summary of the final unit cell base case model results, and descriptions of related sensitivity cases along with tabulation of selected results.

\subsection{BASE CASE MODEL}

\subsection{MODEL CONSTRUCTION}

The unit cell model of the IPA base case is constructed in accordance with the specifications provided by Mann et al. 1995b. The principal output of the model is a set of fractional release rates to the uppermost aquifer for various contaminant species in the low level fraction of the tank waste inventory. The fractional releases are intended for use in subsequent calculation of drinking water dose at a downgradient well.

The original model construction includes the vadose zone geology from the water table at the unconfined aquifer up to the bottom of the floor of the disposal facility ("vault"), concrete floor of the vault, waste form and backfill soil in the interior of the vault, concrete cover over the vault, 
crushed glass water conditioning layer, and a layer of gravel representing part of the gravel base of the capillary barrier. The model is intrinsically a two-dimensional vertical cross-sectional slice of unit thickness, with lateral $(x)$ direction coincident with the long side ( $1.8 \mathrm{~m}$ length) of the waste container. The total width of the model domain in the x-direction is 1.05 meter. The left side of the model (at $x=0$ ) is an assumed axis of symmetry vertically through the center of the long side of the waste container. The right side of the model (at $x=1.05 \mathrm{~m}$ ) is an assumed axis of symmetry through the center of the $30 \mathrm{~cm}$ interval of backfill soil between the short sides ( $1.2 \mathrm{~m}$ length) of two containers. The resulting model profile is shown in Figure 1 . The model is referred to as a unit cell model, not because of the unit thickness in the third space dimension, but because the fractional release rates to the aquifer are estimated from a source term representing a single cell (waste container) in the disposal system which will actually accomodate thousands of containers.

Assignment of hydraulic parameters for the vadose zone and construction materials in the model is made in accordance with base case specifications. For completeness it should be noted that hydraulic properites of gravel are assigned to both the crushed glass water conditioning layer and the fractured glass monolith waste form in the unit cell model. A summary of the hydraulic parameter values assigned to the materials represented in the model is shown in Table 1 .

Table 1. Summary of Hydraulic Parameter Values

\begin{tabular}{|c|c|c|c|c|c|}
\hline $\begin{array}{c}\text { Material } \\
\text { Type }\end{array}$ & $\begin{array}{c}\boldsymbol{\theta}_{\mathrm{s}} \\
\left(\mathrm{m}^{3} / \mathrm{m}^{3}\right)\end{array}$ & $\begin{array}{c}\boldsymbol{\theta}_{\mathrm{r}} \\
\left(\mathrm{m}^{3} / \mathrm{m}^{3}\right)\end{array}$ & $\begin{array}{c}\alpha \\
\left(\mathrm{m}^{-1}\right)\end{array}$ & $\begin{array}{c}n \\
(\text { Unitless })\end{array}$ & $\begin{array}{c}\mathbf{K}_{\mathrm{s}} \\
(\mathrm{m} / \mathrm{yr})\end{array}$ \\
\hline Backfi11 & 0.3710 & 0.0450 & 6.83 & 2.080 & 9467.3 \\
\hline Grave1 & 0.5180 & 0.0140 & 353.66 & 2.661 & 583815.6 \\
\hline Concrete & 0.2258 & 0.0000 & $7.6 \mathrm{e}-4$ & 1.393 & $1.18 \mathrm{e}-4$ \\
\hline $\begin{array}{c}\text { Hanford } \\
\text { Sand }\end{array}$ & 0.3578 & 0.0246 & 15.66 & 2.1768 & 3692.2 \\
\hline $\begin{array}{c}\text { Hanford } \\
\text { Gravel }\end{array}$ & 0.1312 & 0.0126 & 1.25 & 1.530 & 416.6 \\
\hline Ringold E & 0.1342 & 0.022 & 1.22 & 1.5865 & 27.58 \\
\hline \hline
\end{tabular}

The fractional radionuclide release rate from the waste form is assumed to be constant at the maximum value of $f_{0}=1.4 \times 10^{-13} \mathrm{sec}^{-1}=4.418 \mathrm{x}$ $10^{-6} \mathrm{yr}^{-1}$. The duration of the constant source term assuming no loss due to radioactive decay is simply $T=1 / f_{0}=226343.5 \mathrm{yr}$. An effective release duration for constant release of relatively short-lived species including loss due to decay could be calculated as in Appendix $A$ of the report by $K 1$ ine et a). 1983 .

The source region does not exactly represent the size and shape of a waste container enclosing a stack of fractured glass monoliths because of the assumed axis of symmetry for the left side boundary and because of the two- 
dimensional nature of the model. According to the description given previously for the modeled source region, the source volume is

$$
V_{0}=0.9 \mathrm{~m}(1) \times 1.0 \mathrm{~m}(\mathrm{w}) \times 7.2 \mathrm{~m}(\mathrm{~h})=6.48 \mathrm{~m}^{3} \text {. }
$$

For the unit cell model, the constant source strength is applied uniformly in the source region at the constant volumetric source rate of

$$
F_{0}=f_{0} / V_{0}=6.82 \times 10^{-7} \mathrm{yr}^{-1} / \mathrm{m}^{3} \text {. }
$$

The various species in the low level tank waste inventory are discriminated in the unit cell model only by distribution coefficient, $K_{d}$. The eight $K_{d}$ 's used in the model are: $0,0.0001,0.0006,0.003,0.006,0.015$, 0.04 and $0.1 \mathrm{~m}^{3} / \mathrm{kg}$. These $K_{d}{ }^{\prime} \mathrm{s}$ are applied uniformly to each material type in the model, with the one exception that $K_{d}=0$ is used for all species in the source region ("WASTE FORM" shown in Figure 2). A time history of fractional release rate to the unconfined aquifer is calculated for each $K_{d}$ by the unit cell model.

For the purpose of calculating the effective retardation factor as a function of $K_{d}$ in the model, it is necessary to assume values for the bulk density of the various materials represented jn the model. For this purpose, density of gravel was assumed to be $2620 \mathrm{~kg} / \mathrm{m}^{3}$. Bulk density of all other materials was assumed to be $2720 \mathrm{~kg} / \mathrm{m}^{3}$. These values are consistent with densities assumed for previous unit cell model calculations (Kline 1995) and other modeling performed in support of the revised "white paper" on disposal system design options (Mann et al. 1995a).

A final consideration in the initial model construction phase was calculation of directional components of dispersion. The base case specification (Mann et a1. 1995b) implies that the coefficient of molecular diffusion should be $D_{m}=7.889 \times 10^{-4} \mathrm{~m}^{2} / \mathrm{yr}$ for all species, and that the longitudinal and transverse dispersivities for use with Scheidegger's relations are $8.225 \mathrm{~m}$ and $0.8225 \mathrm{~m}$ respectively. Grid block sizes for the model are comparable to those used in earlier unit cell modeling (Kline 1995). The result is a grid Peclet number uniformly near unity which minimizes numerical diffusion and associated mass balance errors in the solution of the contaminant mass transport equations.

\subsection{BASE CASE MODIFICATIONS}

Over forty computer runs were conducted with the base case unit cell model described above for the purpose of checking the model results to assure that they are reasonable and to verify that fluid (water) volume and mass of a11 contaminant species is conserved. Indeed, unreasonableness of some results and inviolate mass conservation necessitated the many computer runs which have in turn led to some base case modifications. It is not the purpose of this section to chronicle the many checkout runs, but rather to describe the chronic difficulties encountered with the original base case and pinpoint the modifications which have resulted in reasonableness of results, numerical stability, and conservation of contaminant mass and fluid volume. 
The boundary condition for flow at the top of the model postulates effective recharge due to infiltration through the Hanford-type barrier at the rate of

$$
\begin{aligned}
\mathrm{q} & =0.5 \mathrm{~mm} / \mathrm{yr} \text { for } 0<\mathrm{t}<1000 \text { years after disposal } \\
\text { and } \mathrm{q} & =3.0 \mathrm{~mm} / \mathrm{yr} \text { forever after ( } \mathrm{t}>1000 \text { years). }
\end{aligned}
$$

Although there is a secondary capillary barrier under the Hanford-type barrier and above the disposal facility (Mann et al. 1995b), and although the capillary barrier is believed to be effective at further reducing the recharge rate (Kline 1995), no credit is taken for it in the unit cell model (i.e., $a=1$ in Figure 1). But in the unit cell mode1, the top of the model where the recharge boundary condition is imposed is the top of a gravel layer representing the base of the capillary barrier. The low recharge rate is too low to maintain high enough moisture content in the gravel to allow passage of water vertically down through the gravel layers (base of capillary barrier and crushed glass). Indeed, it is expected that the gravel layer will induce lateral flow. Accounting for it in the model with $a=0.1$ or $a=0.01$ only worsens the problem. The net result is instability which is manifested in alternating vertical velocity and fluid volume imbalance on the order of $10^{7} \mathrm{~m}^{3}$ over the simulated time period from $t=0$ to $t=100,000$ years after disposal. For comparison, the exact fluid volume introduced by the recharge boundary condition given above is

$$
\begin{aligned}
Q & =(0.0005 \mathrm{~m} / \mathrm{yr} \times 1000 \mathrm{yr}+0.003 \mathrm{~m} / \mathrm{yr} \times 99,000 \mathrm{yr}) \times 1.05 \mathrm{~m}^{2} \\
& =312.375 \mathrm{~m}^{3} .
\end{aligned}
$$

Removing the top six rows of nodes in the model, which is equivalent to stripping off the two gravel layers at the top of the model and the concrete vault ceiling represented in Figure 1, was sufficient to guarantee correct influx through the top of the model and produce reasonable volumetric moisture content (near residual moisture content, $\theta_{r}$ ) in the waste form and backfill regions. However, after the step change in hydraulic properties of the vault floor from concrete to gravelly sand at $t=500$ years after disposal, fluid flow instability and fluid volume imbalance still resulted in the lower (vadose zone) layers of the model. The step change in material properties represents not the cummulative effect of gradual deterioration of one material but rather the relacement of one material (concrete) with static properties by another material (graveliy sand) with a different set of static properties. This step change was simply more than could be accomodated by the model, and could not be rectified by restricting time step size and/or time step growth rate, tightening of convergence criteria, or substitution of other material properties for the gravelly sand properties of the degraded vault floor. Hence, for the modified base case unit cell model, the concrete vault floor shown in Figure 1 is assumed to be degraded initially and is represented by hydraulic properties of gravelly sand from the beginning of the base case simulation ( $t$ ime $t=0$ ).

With those modifications described above, the profile of the base case unit cell model appears to be much the same (except for dimensions) as that used for the revised "white paper" on disposal facility design options. The schematic profile of the modified base case unit cell model is shown in Figure 2 (cf. Figure 5 by Kline 1995). The modified base case unit cell model provides reasonable results, demonstrates stability, and conserves fluid 
volume for the solution to the fluid flow equation. However, the fractional release rate of each species (each $K_{d}$ bin) both through the bottom of the floor zone and through the water table is expected to asymptote to the source value, $f_{0}$, but values of simulated fluxes show that the releases through the floor and into the water table fall far short of the expectation (by almost half).

Now it is important to recall that transport through the source region is expected to be dominated by diffusion (Kline 1995). Fractional release of contaminant mass is uniform over the entire area of the source region, and release from the perimeter of the source region to the backfill soil is likewise nearly uniform (except that there is zero release from the left side of the source region which coincides with a zero flux boundary). The fractional concentration, $C$, of unretarded species within the source region is zero initially, peaks at the value of about $C=7 \times 10^{-3}$ Curies of contaminant per Curie of inventory per cubic meter of water $\left(\mathrm{C} i / \mathrm{C} i-\mathrm{m}^{3}\right.$ ) at about 1025 years, and reaches a steady state value of about $\mathrm{C}=3.33 \times 10^{3} \mathrm{Ci} / \mathrm{Ci}-\mathrm{m}^{3}$ by about 3,000 years after disposal. The concentration at the top of the source creates a relatively steep gradient (approximately $\delta \mathrm{C} / \delta \mathrm{Z}=0.002 \mathrm{Ci} / \mathrm{Ci}-\mathrm{m}^{3}-\mathrm{m}$ ) to the zero concentration boundary at the top of the backfill (1.8 $\mathrm{m}$ away). Considering the relatively high total longitudinal dispersion in the $z-$ direction, it is not surprising that about $40 \%$ of the contaminant flux from the source region goes out through the top of the model. This is regarded here as artificial flux. Accounting for the artifical contaminant flux out of the top of the model in a mass balance calculation shows that there is no mass balance error. But the flux out of the top of the model is only an artifact of the closeness of the top of the model to the top of the source region and the relatively high dispersion. A realistic expectation is that there is no appreciable flux out of the top of the Hanford-type barrier in the real system. Indeed, concerns are for flux down through the vadose zone and into the unconfined aquifer.

Extending the model (backfill soil) vertically upward should help reduce the artificial diffusion through the top of the model, but can only eliminate it perfectly if the extension is infinite. Specifying both zero concentration and a zero gradient (a Cauchy condition) at the top boundary is not well-posed (Arfken 1970). Setting zero concentration at the top of the model assures zero advective flux of contaminant in through the top of the model. The other option is specification of zero diffusive flux (zero gradient) through the top boundary. Implementation of this option would result in a boundary concentration equal to the concentration of contaminant mass that has diffused up to the boundary, which in turn would result in false advection of

contaminant mass into the domain due to the recharge boundary condition. This would create a mass imbalance with overestimation of fractional release at each elevation down through the model. The approach taken here for the modified unit cell model is to implement an artificial diffusion barrier at the top of the model. This is done by setting the coefficient of molecular diffusion, Dm, and the longitudinal and transverse dispersivities, $\alpha_{L}$ and $\alpha_{T}$ respectively, all to zero for all species in the top row of interior nodes (immediately below the row of boundary nodes). Although this creates an infinite Peclet number for those nodes, there is zero contaminant mass at each of those nodes for all time and hence there is no numerical diffusion or associated mass imbalance. Contaminant mass can diffuse up to but not through the row of diffusion barrier nodes, and hence there is also no more artificial diffusion out of the top of the model. This diffusion barrier is an extraneous product of the base case unit cell modeling performed to this 
point, but is regarded as an essential part of the modified unit cell model because it assures reasonable contaminant mass transport results as will be shown in the next section.

\subsection{SUMMARY OF BASE CASE RESULTS}

The base case results summarized here have been obtained with the modified unit cell model described in the previous sections. Moreover, the modified base case (referred to hereafter as the "base case") is the starting point for sensitivity cases described in the following section. All of the unit cell model results have been obtained using Version $2.394 \mathrm{gr}$ of the PORFLOW computer code (Piepho et a1. 1994), the user's guide for which is commonly taken to be the one prepared for Version 2.40 (Runchal and Sagar 1992). All of the graphic summaries of results have been prepared with Version 6.0 of the TECPLOT graphics package (Amtec 1993).

The steady state flow field with the base case unit cell model at 100,000 years after disposal is summarized in Figure 3 which shows the steady state distribution of the saturation fraction $\left(S=\theta / \theta_{s}\right)$ with streamlines. The plot at the bottom of Figure 3 shows the saturation distribution and streami ines over the full space domain of the unit cell model, and the plot at the top of Figure 3 is a blowup of the upper region of the model from $z=75 \mathrm{~m}$ above the water table up to the top of the model at $z=92 \mathrm{~m}$ above the water table. Saturations in the mode1 range from less than 0.03 in the waste form up to about 0.7 in the vault floor zone, as shown in Figure 3 and in Table 2 . Conversion of those saturations into terms of volumetric water content $(\theta)$ is also shown in Table 2. Simulated volumetric water contents range from less than 0.02 up to about 0.09 . The simulated volumetric water content in the waste form is uniformly $\theta=0.014=\theta_{r}$ (residual water content). The volumetric water content in the backfill is nearly uniform, ranging from about 0.06 at the top of the model to about 0.07 immediately above the waste form and along the side of the waste form. The increased water content over the waste form and along the side is expected due to the capillary barrier effect of the sandy ("fine") backfill over the gravelly ("coarse") waste form (cf. Kline 1995). The relatively fine textured backfill diverts flow around the relatively coarser textured waste form, as is shown by the streamlines in both plots in Figure 3 . The saturation in the floor zone appears high from the plots in Figure 3 , but the volumetric moisture content is about 0.09 since the total pore volume and hence the saturated volumetric water content of the sandy gravel in the floor zone is assumed to be $\theta_{\mathrm{s}}=0.1312$ (cf. Table 1). The volumetric water content in the upper Hanford sandy sequence ranges from about 0.04 under the vault floor down to about 0.03 at just under $40 \mathrm{~m}$ above the water table. In the lower Hanford gravelly sequence, simulated volumetric water content ranges from about 0.04 near the top of the sequence to about 0.06 above the interface with the Ringold Formation. In the two-meter-thick slice of the upper Ringold Formation included at the bottom of the model, the volumetric water content is about 0.08 (above the water table).

The plot in Figure 4 is the same as the plot at the bottom of Figure 3 , except instead of saturation contours the plot shows the finite difference grid used for the base case unit cell model with the same two streami ines from Figure 3 . The streamlines in Figure 4 also have time markers starting from the streamline starting point with duration between markers being 5,000 years. Thus from Figure 4 the steady state fluid travel time from the top of the 
WHC-SD-WM-RPT-225, Rev. 0

Table 2. Simulated Steady State Water Contents in the Unit Cell Model

\begin{tabular}{||c|c|c|c|c||}
\hline $\begin{array}{c}\text { Material } \\
\text { Type }\end{array}$ & $\begin{array}{c}\mathrm{S} \\
\text { (Unitless) }\end{array}$ & $\begin{array}{c}\boldsymbol{\theta}_{\mathrm{s}} \\
\left(\mathrm{m}^{3} / \mathrm{m}^{3}\right)\end{array}$ & $\begin{array}{c}\boldsymbol{\theta}=\mathrm{S} \times \boldsymbol{\theta}_{\mathrm{s}} \\
\left(\mathrm{m}^{3} / \mathrm{m}^{3}\right)\end{array}$ & $\begin{array}{c}\boldsymbol{\theta}_{\mathrm{r}} \\
\left(\mathrm{m}^{3} / \mathrm{m}^{3}\right)\end{array}$ \\
\hline Waste Form & 0.02702 & 0.5180 & 0.014 & 0.014 \\
\hline Backfil1 & 0.16 to 0.18 & 0.3710 & 0.06 to 0.07 & 0.045 \\
\hline Floor & 0.7 & 0.1312 & 0.09 & 0.013 \\
\hline Upper Hanford & 0.08 to 0.12 & 0.3578 & 0.03 to 0.04 & 0.025 \\
\hline Lower Hanford & 0.47 to 0.29 & 0.1312 & 0.06 to 0.04 & 0.013 \\
\hline Ringold & 0.62 & 0.1342 & 0.08 & 0.022 \\
\hline
\end{tabular}

vault backfill, down to and around the waste form, to the water table is estimated to be over 25,000 years but less than 30,000 years. By comparison, for the 92 meter distance from the top of the model to the water table with steady recharge at the rate of $q=0.003 \mathrm{~m} / \mathrm{yr}$, the steady state travel time to the water table is estimated to be about 30,700 years. In Figure 4 the streamlines appear to cover a vertical drop of at least $18 \mathrm{~m}$ in the first 5,000 years. In subsequent 5,000 years intervais the vertical drop appears to be no more than about 14 to $15 \mathrm{~m}$ between successive pairs of time markers. This suggests that there is some acceleration along the streamline paths around the waste form. This is reasonable because of the somewhat elevated moisture content around the waste form due to the capillary barrier effect of the backfill around the waste form as discussed above.

Although the steady state travel time from the top of the model to the water table is expected to be around 30,000 years from inspection of the streamlines in Figures 3 and 4 , contaminant travel time from the waste form to the water table is expected to be shorter. This is due in part to the somewhat shorter travel path, but also due to the relatively high dispersivities described earlier. The unretarded base case contaminant travel time will be discussed later in this section, and is also related to at least one of the sensitivity cases.

Time history of instantaneous total fluid flux through a horizontal plane covering the full cross-sectional area of the model at three elevations is shown in Figure 5. After 1,000 years when the recharge rate is $q=3 \mathrm{~mm} / \mathrm{yr}$, the steady state value of instantaneous fluid flux through the model should be

$$
\mathrm{q}^{\prime}=\mathrm{qA}=0.003 \mathrm{~m} / \mathrm{yr} \times 1.05 \mathrm{~m}^{2}=0.00315 \mathrm{~m}^{3} / \mathrm{yr},
$$

where $A=1.05 \mathrm{~m}^{2}$ is the horizontal cross-sectional area of the model. The three curves in Figure 5 show flux through the first row of grid cells ("elements") below the top boundary (dotted curve), flux through the first row of elements below the vault floor zone (dashed curve), and flux through the bottom row of elements above the water table (solid curve). First it is noteworthy in the interest of confimation of the reasonableness of the model results that all three flux curves do indeed asymptote to the exact value of $q^{\prime}$ shown above. Steady state is achieved in the upper regions of the model 
earliest, within about 4,000 years. Convergence to steady conditions all the way down to the water table appears to take about 8,000 years, from inspection of Figure 5. Each of the three curves in Figure 5 shows the effect of the step change in assumed recharge rate at 1,000 years, although the efect at the water table only shows up as a slight dip (undershoot) of the asyptotic value between about 5,000 and 5,500 years. The other prominent effect displayed in Figure 5 is initial drainage from initial prescibed water content down to the steady state water content that is consistent with the recharge rate. For the base case, initial volumetric water content of the backfill and waste form is set at $10 \%(i . e ., \theta=0.10)$, in accordance with base case specifications (Mann et al. 1995). Initial conditions for the Ringold, lower Hanford and upper Hanford are based on an assumed unit hydraulic gradient and an assumed recharge rate of $1 \mathrm{~cm} / \mathrm{yr}$ as being representative of prior rather than future conditions. That initial recharge rate is simply a working assumption.

Over the 100,000 year duration of the base case simulation with the constant fractional release rate of $f_{0}=4.418 \times 10^{-6} \mathrm{yr}^{-1}$, the total fraction of inventory released is 0.4418 or about $44 \%$. From the numerical model results, the total fractional flux of contaminant species $C\left(K_{d}=0\right)$ from the vault floor into the top of the upper Hanford sandy sequence is 0.4419 . This admits a contaminant mass balance error of about 0.0001 , or about one onehundredth of one percent. However at earlier times (within about the first few thousand years of the simulation), the mass balance error is greater because of oscillatory fluxes while the piecewise constant (discontinuous) initial pressure head conditions are equilibrating.

The final run of the base case model was started from the steady state saturation distribution represented in Figure 3. The steady state is consistent with the long-term recharge rate of $3 \mathrm{~mm} / \mathrm{yr}$. The vertical component of Darcy velocity, $V=-K \delta \mathrm{P} / \delta \mathrm{z}$, from the bottom of the vault floor into the top of the upper Hanford formation is shown as a dashed curve in the plot at the top of Figure 6 . The (dashed) curve in Figure 6 suggests that the time history of Darcy velocity through the vault floor is smooth. At time zero, the value of the Darcy velocity is $0.003 \mathrm{~m} / \mathrm{yr}(3 \mathrm{~mm} / \mathrm{yr})$, the long-term recharge rate. At about 1,100 years after disposal, the velocity, $V$, out of the floor has declined to about $0.7 \mathrm{~mm} / \mathrm{yr}$. This is because of the step-change in recharge rate down to $0.5 \mathrm{~mm} / \mathrm{yr}$ at time $t=0$ (due to the Hanford-type barrier over the disposal facility). After the step-change in recharge rate back up to $3 \mathrm{~mm} / \mathrm{yr}$ at 1,000 years after disposal (due to degradation of the barrier), the velocity through the bottom of the vault floor increases quickly from the minimum of about $0.7 \mathrm{~mm} / \mathrm{yr}$ at about $t=1,100$ years up to about 2.7 $\mathrm{mm} / \mathrm{yr}$ by about $t=1,500$ years, and gradually increases close to the long-term recharge rate of $3 \mathrm{~mm} / \mathrm{yr}$ after about $t=4,000$ years after disposal.

The time history of fractional concentration, $C$, for unretarded species at a node immediately under the vault floor is also shown in the plot at the top of Figure 6 . The values of fractional concentration have units of $\mathrm{C} i$ per $\mathrm{C} i$ of inventory per unit volume of water (or units of $\mathrm{kg}$ per kilogram of inventory per unit volume of water). Note that the only bound on concentration is $\mathrm{C}=0$ along the top boundary of the model (cf. Figure 2). otherwise the fractional concentration at a node in the model is determined by fractiona 1 flux into and out of the cell centered at the node (i.e., change in storage from one time step to the next). The fractional release rate from the waste form is a flux boundary condition and is not a constraint on the nodal values of fractional concentration. 
It is expected that transport through the model is dominated by advection (i.e., transport due to movement with moisture as opposed to molecular diffusion through the moisture and dispersion/mixing). The product of $V$ and $C$ from the top plot in Figure 6 is shown in the bottom plot in Figure $6 . V \times C$ $x$ Area is advective fractional flux, and is almost identical to the total (advective plus diffusive) fractional flux shown for $C$ in Figure 7 . Hence the model results show the dominance of advection as the mode of transport through the vadose zone away from the waste form (within the unit cell model).

Fractional release rates (fluxes) of contaminants to the vadose zone (through the vault floor) are shown for four species in the top plot in Figure 7. Fractional release rates (fluxes) to the water table are shown in the bottom plot in Figure 7. Correspondence of contaminant "bin" names to $K_{d}$ bins is shown in Table 3 below. All of the curves in Figure 7 show the effects of the initial drainage and step changes in recharge rate, as described above and illustrated in Figure 6 . Each curve also asymptotes to the expected value of $f_{0}=4.418 \times 10^{-6} \mathrm{yr}^{-1}$. The plots shown in Figure 7 will be the standard for comparison and discussion of the sensitivity cases. Most of the sensitivity cases are ultimately focused on finding variations to which the release rates show some sensitivity. Moreover, the fractional rate of contaminant release to the water table $\left(f_{w t}\right.$ ) is the principal output from the unit cell model for the IPA. From the final run of the base case unit cell model, the fractional release rate of unretarded species (bin $C, K_{d}=0$ ) to the water table at 10,000 years is $4.37 \times 10^{-6} \mathrm{yr}^{-1}$. At about 2150 years, the fractional release rate of species represented by bin $C$ to the water table is about $6.9 \times 10^{-6} \mathrm{yr}^{-1}-$ a product of increasing velocity (V) after the step change in recharge rate back up to $3 \mathrm{~mm} / \mathrm{yr}$ from $0.5 \mathrm{~mm} / \mathrm{yr}$ and availability of concentration (C) that was stored during the initial thousand year period of reduced recharge rate (cf. Figure 6 ). Beyond 10,000 years, the peak fractional release rate at the water table is the asymptotic value $\mathrm{f}_{\mathrm{wt}}=4.42 \times 10^{-6} \mathrm{yr}^{-1}$, by about 17,500 years after disposal.

Table 3. Correspondence of Contaminant Bins and $K_{d}$ Bins

\begin{tabular}{|c|c|c|}
\hline $\begin{array}{c}\text { Contaminant } \\
\text { Bin Name }\end{array}$ & $\begin{array}{c}\text { Typical Units } \\
(\mathrm{m}) / \mathrm{gr})\end{array}$ & $\begin{array}{c}\mathrm{K}_{\mathrm{d}} \text { Bin } \\
\left(\mathrm{m}^{3} / \mathrm{kg}\right)\end{array}$ \\
\hline $\mathrm{C}$ & 0 & 0 \\
\hline $\mathrm{C} 2$ & 0.1 & 0.0001 \\
\hline $\mathrm{C3}$ & 0.6 & 0.0006 \\
\hline $\mathrm{C} 4$ & 3 & 0.003 \\
\hline $\mathrm{C5}$ & 6 & 0.006 \\
\hline $\mathrm{C} 6$ & 15 & 0.015 \\
\hline $\mathrm{C} 7$ & 40 & 0.04 \\
\hline $\mathrm{C} 8$ & 100 & 0.1 \\
\hline
\end{tabular}


WHC-SD-WM-RPT-225, Rev. 0

\subsection{SENSITIVITY CASES}

Each of the 22 sensitivity cases described in this section is a single variation (i.e., only one thing is changed at a time) from the final run of the modified base case unit cell model described in Section 2 . Each is started from the steady state saturation distribution illustrated in Figure 3 , except as noted otherwise for compatibility with assumed long-term recharge rates (cf. Sections $3.3,3.4$ and 3.5 ). The results of each sensitivity case are characterized by time history of fractional release rates through the vault floor and to the water table (such as in Figure 7 for the base case). From each case, fractional release to the water table $\left(f_{w t}\right.$ ) at 10,000 years, maximum fractional release rate to the water table during the ful1 100,000 year period of simulation, and time of occurrence of the peak value of $f_{w t}$ are compiled in Table 4. For the purpose of creating Table 4, the base case (final run) results comprise sensitivity case number 0 .

\subsection{SENSITIVITY CASE 1}

\section{Steady Flow with $q=3 \mathrm{~mm} / \mathrm{yr}$}

Sensitivity Case 1 is the same as the final run of the base case described in Section 2, except that the recharge rate is constant at $q=3$ $\mathrm{mm} / \mathrm{yr}$ from the beginning $(t=0)$ for the entire duration of the run (i.e., there is no initial thousand year period of reduced recharge from the Hanford type barrier). Correspondingly the fractional release rate to the water table for bin $C$ increases monotonically from 0 at $t$ ime $t=0$ up to the asymptotic value of $4.42 \times 10^{-6} \mathrm{yr}^{-1}$ by about 4,400 years after disposal, as shown in Figure 8 .

\subsection{SENSITIVITY CASE 2}

\section{Transient Flow, $q=3 \mathrm{~mm} / \mathrm{yr}$ with Initial $\theta=0.1$ in the Vault}

Sensitivity Case 2 is the same as the final run of the base case, except that the initial volumetric moisture content of the construction materials (i.e., waste form, backfill and vault floor) is $\theta=0.1$. This is higher than the respective steady state moisture contents for the three materials as shown in Table 2. However, the differences are relatively small and the model re-equilibrates quickly. There is no detectable difference between the base case and this sensitivity case in terms of frational release rate history at the water table (cf. Table 4). The fractional release rate time histories for this case are shown in Figure 9 (cf. Figure 7).

\subsection{SENSITIVITY CASE 3}

\section{Steady Flow with $q=1 \mathrm{~mm} / \mathrm{yr}$}

Sensitivity Case 3 is the same as the base case, but with constant recharge rate of $q=1 \mathrm{~mm} / \mathrm{yr}$. The simulation is started from the corresponding steady state with the same recharge rate $(q=1 \mathrm{~mm} / \mathrm{yr})$. The reduced recharge rate could be due to change in land use; but with the unit cell mode1, it can as well represent a case of long-term effectiveness of the capillary barrier with $q=3 \mathrm{~mm} / \mathrm{yr}$ and barrier effectiveness parameter $\mathrm{a}=1 / 3$ (cf. Figure 2). Discussion of capillary barrier performance is given by Kline 
1995. For this case, the peak value of $f_{-y t}$ at 10,000 years is $4.41 \times 10^{-6} \mathrm{yr}^{-}$ ${ }^{1}$. The maximum value of $f_{w t}$ is $4.42 \times 10^{-y^{t}} \mathrm{yr}^{-1}$ at about 12,000 years. The fractional release rate time histories for this case are shown in Figure 10.

\subsection{SENSITIVITY CASE 4}

\section{Steady Flow with $q=0.1 \mathrm{~mm} / \mathrm{yr}$}

Sensitivity Case 4 is another case of reduced recharge rate, $q=0.1$ $\mathrm{mm} / \mathrm{yr}$, or equivalently another case of capillary barrier effectivness with $a=1 / 30$. The simulation was started from the corressponding steady state with constant recharge rate of $q=0.1 \mathrm{~mm} / \mathrm{yr}$. The value of $f_{w t}$ at 10,000 years is about $5.9 \times 10^{-8} \mathrm{yr}^{-1}$; the peak value of $f_{w t}$ is $4.48 x^{\text {wt }} 10^{-6} \mathrm{yr}^{-1}$ at about 68,000 years. Fractional release rate time histories for this case are shown in Figure 11.

\subsection{SENSITIVITY CASE 5}

\section{Steady Flow with $q=100 \mathrm{~mm} / \mathrm{yr}$}

Sensitivity case 5 is a case of increased long-term recharge rate, $q=$ $100 \mathrm{~mm} / \mathrm{yr}$, and is started from the corresponding steady state. For this case, fractional release rate of species $C$ to the water table is approximately $f_{w t}=4.44 \times 10^{-6} \mathrm{yr}^{-1}$ at 10,000 years. The maximum value of fractional release of species $C$ to the water table is $f_{w t}=4.73 \times 10^{-6} \mathrm{yr}^{-1}$ at about 200 years. These results are from the simulation used to produce the release rate histories shown in Figure 12a.

As suggested in the history plots of fractional release rates to both the water table and especially through the vault floor to the vadose zone for this case in Figure 12a, there is some oscillatory behavior which could be symptomatic of oscillatory wetting and drying or possibly instability; in either case it might be indicative of fluid volume and/or contaminant mass imbalance. The top plot in Figure 12a suggests that the disturbance is amplified from about $t=1,000$ to about $t=1,400$ years after disposal. This corresponds to the beginning of a period of time in which simulation control parameters were changed for the AUTOmatic time stepping option. The bottom plot in Figure 12a suggests that the oscillations might be most prominent for unretarded species (C).

From the simulation results that were used to produce Figure $12 \mathrm{a}$, the cummulative fluid volume and contaminant mass balance errors are about 0.003 and 0.03 , respectively, after 100,000 years. Those errors are not symptomatic of instability, but the $3 \%$ contaminant mass balance error is unacceptable. The difficulty is oscillatory wetting and drying that occurs numerically while the model is equilabrating to steady state; $i . e$. , for this high recharge rate case, the time to steady state is much longer than for the other cases. The preconditioning was about 10,000 years. With further preconditioning of the starting conditions out to a full 100,000 years, results of Case 5 are much improved as shown in Figure 12b. For this extended case, the peak release rate of unretarded species (C) to the water table is the asymptotic rate of $4.42 \times 10^{-6} \mathrm{yr}^{-1}$ within the first 600 years. The release rate at 10,000 years is also the asymptotic rate, i.e. $f_{w t}=f_{0}$ after about 600 years; however, as suggested by Figure $12 \mathrm{~b}$, some small oscillations persist at both the elevation 
of the bottom of the vault floor and the water table. The results of the extended case represented by Figure $12 \mathrm{~b}$ are nonetheless improved in that the cummulative contaminant mass balance error is reduced from 0.03 to 0.003 after 100,000 years.

The starting conditions are intended and assumed to be representative of the appropriate steady state. In this case the starting conditions are not yet perfectly conditioned. A reasonable expectation is that the oscillations can be eliminated with even further preconditioning (smoothing) of the starting conditions. This has not been carried out because of the extremely long computer run times already incurred for this case. The original Case 5 along with the preconditioning for the extended case took several days of computer time on an IBM RISC System/6000 Model 580; the extended case took about another twelve hours (another overnight run) - even with the unit cell model. Further extension of this case is not likely to produce substantial changes or more meaningful results.

\subsection{SENSITIVITY CASE 6}

\section{A11 of Hanford Formation is Sandy Sequence}

Sensitivity Case 6 is the same as the final run of the base case except that all of the vadose zone from the bottom of the vault floor down to the Ringold $E$ layer is assumed to be homogeneous with properties of the upper Hanford sandy sequence. The fractional release rate of species $C$ at the water table is constant at the asymptotic rate $f_{w t}=4.42 \times 10^{-6} \mathrm{yr}^{-1}$ after about 5,000 years. The peak release rate of species $C$ is about $6.25 \times 10^{-6} \mathrm{yr}^{-1}$ at about 2,500 years, as suggested in Figure 13. A notable feature of Figure 13 is the brief period of oscillatory behavior in fractional releases to the water table for species $C$ and $C 2$ between about 2,000 and 3,000 years after disposal. Those oscillations aren't shown in the releases through the vault floor to the underlying upper Hanford sandy sequence; i.e., the disturbance doesn't seem to be temporal but rather spatial. In particular, the interface between the vertically extensive sandy sequence and the Ringold Formation is only two meters above the water table. At the interface, the saturated conductivity $\left(\mathrm{K}_{\mathrm{s}}\right)$ drops from about $10^{-2} \mathrm{~cm} / \mathrm{s}$ in the sandy layer to about $9 \mathrm{x}$ $10^{-5} \mathrm{~cm} / \mathrm{s}$ in the Ringold ( $\mathrm{cf}$. Table 1). When the wetting front caused by the step up in recharge rate at the top boundary at 1,000 years reaches the interface between the sandy sequence and the Ringold, the bottom row of interior nodes representing the Ringold in the model acts temporarily as a barrier. This is manifested as an increased hydraulic gradient into the Ringold and proportionate increase in the Darcy velocity into the Ringold (and through the Ringold Formation into the water table). Moreover, the porosity $\left(\theta_{s}\right.$, approximately) drops dramtically at the interface from about $36 \%$ of the porous medium by volume in the sandy sequence to about $13 \%$ in the Ringold Formation. Influx of contaminant across the interface into the Ringold can result in increasing contaminant concentration in the Ringold. The result of increasing velocity through the Ringold and increasing concentration in the Ringold is sharply increasing flux across the water table in the model. Although the oscillatory behavior associated with the increasing flux in the 
model is likely to be aphysical and the peak value of $f_{w t}=6.25 \times 10^{-6} \mathrm{yr}^{-1}$ might be overestimated, the cumulative contaminant mass balance error for this case is about 0.0001 ( 0.01 percent).

\subsection{SENSITIVITY CASE 7}

\section{Filler Material is Hanford Sand (instead of Backfill Soil)}

For this variation of the base case, the filler material in the vault between and above the waste form is assigned the physical and hydraulic properties of the Hanford sandy sequence rather than backfill soil. Inspection of hydraulic properties in Table 1 suggests that there is little difference between the two materials. Simulation results support that conjecture. The simulated peak value of fractional release of unretarded species to the water table is about $4.73 \times 10^{-6} \mathrm{yr}^{-1}$ at about 2150 years, and the value at 10,000 years is about $4.37 \times 10^{-6} \mathrm{yr}^{-1}$. Fractional release rate time history plots for this case are shown in Figure 14.

\subsection{SENSITIVITY CASE 8}

\section{Lower Hanford Gravel Layer Thickness is $50.5 \mathrm{~m}$}

For the base case model, the Hanford sandy sequence layer thickness is 45.25 meters and the underlying Hanford gravelly sequence layer thickness is 35 meters, as shown in Figure 2. The total thickness of the Hanford sandy and gravelly sequences is 80.25 meters. For the present sensitivity case, that total thickness remains constant, but the lower Hanford gravelly layer thickness is taken to be 50.5 meters and the overlying sandy sequence layer thickness is the remaining 29.75 meters.

Simulated fractional release rates from this case are summarized in Figure 15, and are similar to those from the base case displayed in Figure 7 . The peak release to the aquifer is about $\mathrm{f}_{w t}=8.53 \times 10^{-6} \mathrm{yr}^{-1}$ at about 2,000 years after disposal. The release rate at 10,000 years is about $4.2 \times 10^{-6}$ $\mathrm{yr}^{-1}$.

\subsection{SENSITIVITY CASE 9}

\section{Water Table at $110 \mathrm{~m}$ Below Land Surface (bls)}

For this sensitivity case, the depth of the water table is assumed to be 7 meters deeper than the 103 meter depth of the water table assumed for the base analysis case (Mann et al. 1995b). This required vertical extension of the computational grid so that the Ringold layer is 9 meters in thickness and the water table boundary condition at the bottom of the grid is at 110 meters below land surface. The principal difference between the results of this case and the results of the base case is a slight delay in arrival time of peak flux to the water table. This is due simply to the slightly greater depth to the water table for this simulation case. Otherwise the results from this case are similar to the results from the base case, as can be seen in Table 4 and by comparison of Figure 16 to Figure 7 . 


\subsection{SENSITIVITY CASE 10}

\section{Water Table at $96 \mathrm{~m} \mathrm{bls}$}

In this case the water table is assumed to be 7 meters more shallow than in the base case. As with the previous case of less than $10 \%$ variation in depth to the water table, the distinction of the results from the base case is minimal. This can be seen upon inspection of Table 4 and Figure 17.

\subsection{SENSITIVITY CASE 11}

\section{Initial $\theta=0.2$ in Construction Materials}

Sensitivity Case 11 is related to Case 2 in which the initial volumetric moisture content of the construction materials (i.e., vault floor, waste form and filler) was set at $10 \%$, slightly above initial/steady state moisture content of the vault floor and filler (cf. Table 2). The biggest perturbation of initial moisture content for Case 2 was in the waste form which generally stays at residual moisture content in the model due to wicking of water around the waste form through the filler. Comparison of results to the base case was unremarkable.

Sensitivity Case 11 is a larger perturbation of initial moisture content in the construction materials. For this case initial $\theta=0.2$ in the construction materials, twice the initial moisture content used for construction materials in Case 2. As can be seen from Table 4 and comparison of Figure 18 to Figure 7, the difference in results from the base case is still unremarkable.

\subsection{SENSITIVITY CASE 12}

\section{Initial $\theta=\theta_{r}$ in Construction Materials}

For Sensitivity Case 12 , the initial volumetric moisture content of the construction materials was set to the residual volumetric moisture content, $\theta=\theta_{r}$. As with Cases 2 and 11 discussed above, there is no appreciable difference from the base case in terms of the results summarized in Table 4 and Figure 19. To examine this, note that the volume of the construction materials for the unit cell model as shown in Figure 2 is $9.75 \mathrm{~m} \times 1.05 \mathrm{~m} \times 1$ $\mathrm{m}=10.2375 \mathrm{~m}^{3}$. Let $\mathrm{v}_{0}$ denote the initial volume of moisture in the construction materials. As shown below,

$$
\begin{array}{cc}
\text { Initial } \theta & \text { Initial } v_{0}\left(\mathrm{~m}^{3}\right) \\
\theta_{\mathrm{r}} & 0.1 \\
0.1 & 1 \\
0.2 & 2
\end{array}
$$

the initial volume of moisture in the construction materials ranges from about 0.1 cubic meter for the present Case 11 up to about 2.0 cubic meters for the preceeding Case 10. However, the total volume of water, $Q$, entering the model through the recharge boundary at the top of the filler is over 300 cubic meters (Section 2.2). So for each of the initial moisture content perturbations, the ratio $v_{0} / Q$ is small (7ess than $1 \%$ ); $i . e$. , the initial volume of moisture in the construction materials is small compared to the 
WHC-SD-WM-RPT-225, Rev. 0

influx of moisture over the 100,000 year duration of each of the simulations. The point here is that for a perturbation of $v_{0}$ to have significant impact on results, it must not only be significant compared to the base case value of $v_{0}$ but it must also be significant compared to $Q$ to have impact on the flow field.

\subsection{SENSITIVITY CASE 13}

\section{Intercanister Spacing $=90 \mathrm{~cm}$}

Sensitivity Case 13 is a 90 degree rotation about the z-axis. With respect to Figure 2 , the $x$-axis direction for this case is orthogonal to that of the base case. The difference between this case and the base case is that the spacing between waste form stacks increases from $30 \mathrm{~cm}$ to $90 \mathrm{~cm}$. The half-width of the filler region becomes $45 \mathrm{~cm}$. At the same time, the new profile of the waste form has a $60 \mathrm{~cm}$ half-width. Hence the the total width of the mode1 (in the $x$-direction) remains 1.05 meters.

The net effect of this rotated geometric perspective is a greater volume of filler in which to wick water around the waste form. However, since the filler in the base case was less than $20 \%$ saturated (Table 2), it is reasonable to expect that the enlarged filler zone in this case will not have a substantial impact on flow and transport results. This is bourne out by results shown in Figure 20 and Table 4 which suggest that arrival time at the water table for this case is about 50 years longer for unretarded species than in the base case.

\subsection{SENSITIVITY CASE 14}

\section{Double Number of Nodes Laterally}

This sensitivity case is the base case with double the number of nodes laterally (in the $x$-direction). Whereas the base case model employed 8 interior nodes and 2 boundary nodes in the $x$-direction, for this case the computational grid consisted of 16 interior nodes and 2 boundary nodes in the $x$-direction. The increased nodal resolution laterally obtained no significant effect on the flow and transport results as suggested by Table 4 and Figure 21. This in turn suggests that further increase in lateral nodal density would be unproductive. The lateral direction is important for this convergence check since it is the lateral direction which allows for the capillary barrier effect and wicking of moisture around the waste form in the model. Otherwise the model is one-dimensional; stability of results demonstrated by smoothness of time history plots at two elevations (floor and water table) suggest convergence in the z-direction.

\subsection{SENSITIVITY CASE 15}

\section{Waste Form has Hydraul ic Properties of Sand}

For this case the physical, hydraulic and transport properties of the waste form are assumed to be the same as the upper Hanford sandy sequence (instead of gravel as in the base case). With this variation of material properties, the peak fractional release rate of unretarded species at the 
WHC-SD-WM-RPT-225, Rev. 0

water table is $\mathbf{f}_{w t}=5.72 \times 10^{-6} \mathrm{yr}^{-1}$ at about 2,200 years after disposal. At 10,000 years after disposal, the fractional release rate to the water is 4.37 $\times 10^{-6} \mathrm{yr}^{-1}$. Release time histories for this case are shown in Figure 22 .

\subsection{SENSITIVITY CASE 16}

\section{$\underline{D m}=10^{-8} \mathrm{~cm}^{2} / \mathrm{sec}\left(=3.156 \times 10^{-5} \mathrm{~m}^{2} / \mathrm{yr}\right)$ Everywhere}

The diffusion coefficient was reduced by a factor of $1 / 20$ from the base case value down to $3.156 \times 10^{-5} \mathrm{~m}^{2} / \mathrm{yr}$ for this sensitivity case. No significant change is detectable in the results, as suggested by Table 4 and Figure 23.

\subsection{SENSITIVITY CASE 17}

Doubled Longitudinal and Transverse Dispersivities $\left(2 \alpha_{L}, 2 \alpha_{T}\right)$

Doubling the values of both the longitudinal and transverse dispersivities, $\alpha_{L}$ and $\alpha_{T}$ respectively, for this case results in a reduction of peak value of fractional release rate to $f_{w t}=5.89 \times 10^{-6} \mathrm{yr}^{-1}$ for unretarded species at an earlier time of about 1,990 years after disposal. The value after 10,000 years is unchanged at $\mathrm{f}_{\mathrm{ut}}=4.37 \times 10^{-6} \mathrm{yr}^{-1}$. These results are also suggested by Figure 24. However, the base case values of the dispersivities (Section 2.1) are probably already high and analysis of doubling them is probably less important than the following cases of reduced dispersivity.

\subsection{SENSITIVITY CASE 18}

\section{Halved Longitudinal and Transverse Dispersivities $\left(\alpha_{L} / 2, \alpha_{T} / 2\right)$}

This case shows the effect of halving both the longitudinal and transverse dispersivities. The result is a peak release rate of $f_{w t}=8.01 \times$ $10^{-6} \mathrm{yr}^{-1}$ at about 2,270 years after disposal for unretarded species. Halving the dispersivities increases the peak release rate to the water table and increases the arrival time of the peak at the water table. This is opposite the effect shown for the previous case of doubling the dispersivities, as should be expected. Results from this case are summarized in time histories of arrivals shown in Figure 25.

\subsection{SENSITIVITY CASE 19}

\section{Order of Magnitude Reduction in Dispersivities $\left(\alpha_{L} / 10, \alpha_{T} / 10\right)$}

This case was run to show the effect of order of magnitude reduction in dispersivities. Similarly to Case 18, this case should produce greater increases in both peak release rate and time of arrival at the water table. Although the base case dispersivities are large, order of magnitude reduction in dispersivity also leads to an order of magnitude increase in the grid Peclet number. For the one-dimensional vertical transport of contaminants 
downward from the vault floor to the water table, the local (nodal) value of the grid Peclet number (Kline et al. 1983; Eyler and Budden 1984) is

approximately

$$
\mathrm{Pe}=\Delta z / \alpha_{L} .
$$

The maximum $\Delta z$ in the computational grid (Figure 4 ) is 8 meters near the middle of the upper Hanford sandy sequence. The base case value of the longtudinal dispersivity is $\alpha_{1}=8.225$ meters. Hence the maximum value of the grid Peclet number is about unity for the base case, but about $\mathrm{Pe}=10$ for the present case with order of magnitude decrease in dispersivity. For Peclet numbers greater than 2, the solution to the transport equation automatically switches to upwinding (Runchal and Sagar 1992). High values of the Peclet number are indicative of advection dominated transport which can induce numerical diffusion. The use of upwinding for $\mathrm{Pe}>2$ smoothes sharp advective fronts and reduces the likelihood of numerical diffusion but also introduces numerical dispersion. Piepho et al. 1994 conclude that numerical dispersion introduced by upwinding in the PORFLOW codes is contolled by maintaining a Peclet number of no more than 20. Eyler and Budden 1984 showed onset of unacceptably high numerical dispersion with the PORFLO code for a simple unidimensional mass transport verification problem with $\mathrm{Pe}>12 \mathrm{globa} 1 \mathrm{y}$. This present low dispersivity case with grid Peclet number ranging up to about $\mathrm{Pe}=10$ is expected to obtain a reasonably accurate solution.

The peak fractional release rate of unretarded species at the water table is $f_{u t}=10.2 \times 10^{-6} \mathrm{yr}^{-1}$ at about 2,350 years after disposal for this case. At 10,000 years after disposal, the fractional release rate to the water table is about $4.37 \times 10^{-6} \mathrm{yr}^{-9}$ for unretarded species. Time histories of fractional release rates shown for this case in Figure 26 suggest that the delayed arrival due to decreased dispersivity might be most pronounced for the species with higher retardation factors.

\subsection{SENSITIVITY CASE 20}

\section{$\underline{K}_{d}=100 \mathrm{ml} / \mathrm{gr}\left(=0.1 \mathrm{~m}^{3} / \mathrm{kg}\right)$ in Vault Floor for All Species}

For Sensitivity Case 20, the distribution coefficient was the same as in the base case except that $K_{d}=100 \mathrm{ml} / \mathrm{gr}$ was assumed to be effective for all species in the vault floor. With this retardation barrier in effect, release from the vault floor to the Hanford sandy sequence and release to the water table was slowed dramatically for all species, as depicted in Figures 27 a and $27 \mathrm{~b}$. For this case, the fractional release rate of unretarded species to the water table is about $f_{w t}=8 \times 10^{-8} \mathrm{yr}^{-1}$ at 10,000 years after disposal. The peak release rate of unretarded species to the water table in the simulated 100,000 year time period is about $3.99 \times 10^{-6} \mathrm{yr}^{-1}$ at the end of the 100,000 year period.

\subsection{SENSITIVITY CASE 21}

\section{Analytic Time Dependent Source Term}

This case is identical to the base case except that the source strength is not held constant at the peak initial value $f_{0}$, but is assumed to decrease montonically from that value with increasing time. The time dependent source strength is 


$$
\begin{gathered}
\text { WHC-SD-WM-RPT-225, Rev. } 0 \\
f(t)=f_{0} *(T-t)^{2} / T^{2} \text {, where } T=680,000 \text { years, }
\end{gathered}
$$

which is an ammended version of that shown in Table 11-1 of the base case specification by Mann et a1. 1995b. As an approximation, Piepho 1996 used

$$
f(t)=3 *(T-t)^{2} / T^{3}
$$

for the base case and related sensitivity cases with the full facility model. The Piepho 1996 approximation to $f(t)$ is used for this sensitivity case, and is shown graphically in comparison to the constant value of $f_{0}$ in Figure 28 .

At time $t=0, f(0)=f_{0}$; at $t=680,000$ years, $f$ has declined to exactly zero. At $t=100,000$ years, the value of $f$ is about $3.2 \times 10^{-6}$ which is only about a $27 \%$ reduction from the initial value of $f_{0}$. Therefore the time dependence of the source strength is not expected to have a substantial impact on the 100,000 year simulation of the base case.

The peak fractional release rate of unretarded species at the water table is $f_{\text {t }}=6.87 \times 10^{-6} \mathrm{yr}^{-1}$ at about 2,150 years after disposal, which is almost identical to the base case (Table 4, Figure 29). The release rate at 10,000 years is about $f_{w t}=4.26 \times 10^{-6} \mathrm{yr}^{-1}$, which is also the secondary peak value centered at about 11,400 years. This secondary peak is a little lower in value and a little earlier in time than in the base case because of the gradual decline of the source strength. The primary peak in release rate to the water table is more a function of the drainage/storage caused by the step changes in the recharge rate, as explained near the end of Section 2.3, and is largely unaffected by the modest decline in source strength in the first few thousand years after disposal.

\subsection{SENSITIVITY CASE 22}

\section{Source Term Computed By AREST Code}

For this final variation of the base case, the source term was taken from release rates simulated with the AREST-CT code (Chen et al. 1995). For this case, vadose zone transport of particular species was simulated instead of using the generic $K_{d}$ bins from Table 3 . Release rates of eight particular species were provided from the AREST-CT simulations of release from the waste form. Those eight species are shown below.

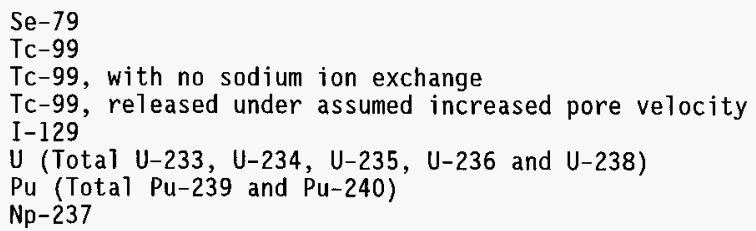

Since the AREST-CT code is innately one-dimensional, simulated release rates were provided as fluxes out of the bottom of the waste form and into the vadose zone at approximately the depth of the vault floor. Those fluxes were converted to fractional release rates, most of which are shown in Figure 30 . Note that the base Tc-99 release rate is shown in Figure 30; the Tc-99 release rates with special assumptions are off the scale of the plot. Tc-9g release 
without sodium ion exchange is much slower than the base release rate shown in Figure 30. Tc-99 release with assumed constant pore velocity of $V^{\prime}=10 \mathrm{~cm} / \mathrm{yr}$ in the AREST-CT simulation is much faster than the base rate of Tc-99 release shown in Figure 30. [Note: Vertical pore velocity is $V^{\prime}=V / \phi$, where $\phi$ denotes porosity.] The AREST-CT simulation results for Np-237 are not accurate (McGrail 1996), and are the subject of further work. The Neptunium release rates seem to be at least an order of magnitude too high, and are not shown in Figure 30. However, the simulated $\mathrm{Np}-237$ release rate was used for Neptunium transport in Sensitivity Case 22. Assignment of $\mathrm{K}_{\mathrm{d}}{ }^{\mathrm{s}} \mathrm{s}$ for the particular species in this case was made in accordance with table 12-1 from the base case specification by Mann et al. 1995b. As with the base case, $K_{d}=0$ was assigned for all species in the waste form.

Simulated fractional release rates of selenium, technicium, iodine, uranium and plutonium through the vault floor as well as to the water table for Sensitivity Case 22 are shown in Figure 31 . The obvious differences between the source fractional releases shown in Figure 30 and the release rates from the vaut floor shown at the top of Figure 31 are some smoothing of the profiles in Figure 31 , even though the travel distance across the floor is sma11, and separation of the curves in Figure 31 due to retardation during travel down through the vault floor. Simulated release rates to the water table shown at the bottom of Figure 31 suggest that uranium and iodine peaks at the water table are delayed by about 8,000 years and 40,000 years, respectively, due larely to retardation. Plutonium is so effectively retarded in the numerical simulation that it is not even detectable in the plot of arrivals at the water table shown in Figure 31 . The most important observation concerning release rates for this sensitivity case is that all of the release rates, from the AREST-CT simulation of the source term to the arrivals at the water table, are at most no more than about $20 \%$ of $f_{0}$. Some of the release rates, such as for $\mathrm{Pu}$, are many orders of magnitude less than $f_{0}$ over at least part of the 100,000 year duration of the simulations. Peak values for the eight species included in this simulation case are shown in Table 5 .

\subsection{SUMMARY AND CONCLUSIONS}

The Base Analysis Case for the Interim Performance Assessment (IPA) of low-level tank waste disposal as specified by Mann et al. 1995b is the basis for development of a unit cell model used in analysis of the base case and 22 sensitivity cases reported herein. Although the base case specification (Mann et al. 1995b) is a comprehensive set of input parameter values for all of the IPA flow and transport model calculations, a few assumptions were necessary in setting up the unit cell model (Section 2.1). Preliminary computer runs of the base case with the unit cell model gradually yielded insights that led to modifications of the unit cell model (Section 2.2). The unit ce11 model modifications were driven by attempts to verify/confirm reasonableness of the model results.

The profile of the modified unit cell model (Figure 2) is similar to that of the unit cell model used previously by Kline 1995 for modeling in support of revisions to a report on disposal facility design options (Mann et al. 1995a). An important difference between the two unit cell models is the implementation of a diffusion barrier at the top of the model (at the top of the filler in the disposal vault) for the present case. Without the barrier, artificial diffusion out of the top of the model results in unacceptably high 
contaminant mass balance errors. The artificial diffusion out of the top of the model is largely a product of the relatively high dispersivities inferred from the base case specification. Some discussion of dispersivities is contained in Sections $3.17,3.18$ and 3.19 .

The waste form in the model is assumed to be fractured at the time of disposal, and is assumed to be similar in hydraulic properties to gravel. The filler material between and overlying the waste forms in the vault is assumed to be finer in texture, similar to the upper Hanford sandy sequence. The result is a capillary barrier effect (Kline 1995); the filler material wicks infiltrating moisture around the waste form. This is shown by the streamlines in Figures 3 and 4 . The steady state volumetric moisture contents in the model are low, ranging from about $9 \%$ in the vault floor (assumed to be degraded to gravelly sand), down to residual moisture content, $\theta_{r}=1.4 \%$, in the waste form (Table 2). Although transport within the dry fractured ("gravelly") waste form is assumed to be dominated by diffusion (Kline 1995), transport around the waste form through the filler and down from the vault floor to the water table is dominated by advection (Section 2.3).

Transport of dissolved contaminants by advection and diffusion/dispersion in the moisture distribution is performed in terms of generic contaminant "bins". Each bin has one associated $k_{d}$ value. Each contaminant belongs to one and only one bin. Transport of each contaminant in one bin is identical to the transport of the one generic species represented by the associated $K_{d}$ bin. The $K_{d}$ bins used for this analysis are shown in Table 3 . These bins are used for the base case and all of the sensitivity cases except the last sensitivity case in which transport of particular species is performed.

For the base case and Sensitivity Cases 1 through 21 , the only distinction between contaminant species is the difference between $K_{d}$ assignments $s_{-i}$ Each species has a constant fractional release rate, $f_{0}=4.418 \times 10^{-6} \mathrm{yr}^{-i}$, distributed uniformly within the volume of the source region (Section 2.1). Differences in terms of radioactive decay rates and initial inventories are included in the dose calculations (Mann 1996).

Fractional release rates to the vadose zone $\left(f_{f l}\right)$ from the bottom of the vault floor and to the water table $\left(f_{w t}\right)$ at the bottom of the model are calculated as a function of time for each contaminant bin. These are the primary outputs from the unit cell model and are used in the calculation of doses. Doses are not calculated by use of the GRTPA code (Piepho et a1. 1994) as was done for previous unit cell modeling (KI ine 1995).

Fractional release rates from the base case are shown in Figure 7 . Important values of the fractional release rates are fractional release rate to the water table at 10,000 years after disposal and peak value of fractional release rate to the water table (during the 100,000 year time period of the simulation). From the base case results, the fractional release rate of unretarded species (bin $C, K_{d}=0$ ) to the water table at 10,000 years after time of disposal is about $4.37 \times 10^{-6} \mathrm{yr}^{-1}$. At about 2,150 years, the fractional release rate for bin $C$ to the water table is about $6.9 \times 10^{-6} \mathrm{yr}^{-1}$ - a product of increasing velocity (V) after a step change up in recharge rate and availibility of contaminant concentration (C) that was stored during the 1,000 year period of lower recharge rate (cf. Figures 5 and 6 , and Section 2.3). Beyond 10,000 years after disposal, the peak fractional release rate to the water table for bin $C$ is the asymptotic value $4.42 \times 10^{-6} \mathrm{yr}^{-1}$ by about 17,500 
years after disposal. For retarded species (bins $C 2$ through $C 8$ ), arrival times are generally increased and peak values are generally the asymtotic value $\left(f_{0}=4.42 \times 10^{-6} \mathrm{yr}^{-1}\right)$.

Results of sensitivity cases which involve variations of material properties, initial conditions, depth to the water table, nodal density, filler thickness between waste forms, and relatively slow initial decline of the source strength generally show little difference from the base case results in terms of time history of simulated fractional release rate at the water table. The model does show sensitivity to variations in the recharge rate (Sensitivity Cases $1,3,4$ and 5 ). Response of the model to increases or decreases in the long-term recharge rate is almost linear (Cases 3, 4 and 5). Sudden changes in recharge rate such as a step change in the model can result in spikes in releases to the water table ( $c f$. Case 1 versus Case 0 ). Implementation of a chemical retardation barrier in the vault floor can mitigate spikes; moreover, the simulated performance of the retardation barrier suggests that release rate to the water table can be reduced by at least a factor of $1 / 50$ in the first 10,000 years after disposal if effective $K_{d}$ in the vault floor can be increased up to $100 \mathrm{ml} / \mathrm{gr}$ for all species in the inventory (Sensitivity Case 20).

An important result of this modeling exercise is the simple observation that the results are dominated by the postulated limit on fractional release rate from the waste form. All of the simulated fractional release rates to the water table asymptote to the constant source release rate of $4.42 \times 10^{-6}$ $\mathrm{yr}^{-1}$ (about $4.4 \mathrm{ppm}$ per year), except for Cases 21 and 22 in which the release rates to the water table are dominated by time dependent sources. Sensitivity Case 22 is particularly important because it is based on simulated releases from the source which are estimated to be much lower than the $4.4 \mathrm{ppm} / \mathrm{yr} 1 \mathrm{imit}$ (cf. Figure 30).

Simulated fractional release rates to the water table for Sensitivity Case 22 (Section 3.22) are summarized in Table 5. For Case 22, peak simulated release rate of Tc-99 to the water table is about $5 \times 10^{-7} \mathrm{yr}^{-1}$, an order of magnitude lower than from the base case. Without sodium ion exchange, peak Tc- 99 release rate to the water table is reduced by another $94 \%$ to about $2.8 \times$ $10^{-8} \mathrm{yr}^{-1}$. Assumably the crushed glass water conditioning layer (Figure 1) will reduce the potential for sodium ion exchange in the waste form and thereby help reduce peak Tc-99 release rates.

Another important component of the disposal system is a chemical retardation pad in the floor. Results from Sensitivity Case 20 (Section 3.20) suggest that the retardation pad might help reduce release rates to the water table for unretarded species by as much as $98 \%$ during the first 10,000 years after disposal. Results also suggest that enhanced retardation in the floor might be able to prolong peak releases to the water table (Table 4 ).

The crushed glass water conditioning layer over the disposal facility and the retardation pad in the floor are subject to degration along with the rest of the engineered facility. Therefore it is even more impoprtant that the releases to the water table are dominated by the source release rates. The bulk of the sensitivity cases suggest that the unit cell model is robust in that the base case results are largely unaffected by the substitutions of differing material properties, displacement of the water table, and other 
WHC-SD-WM-RPT-225, Rev. 0

perturbations with the exception of recharge rate. Hence the final conclusion to be drawn from this work is that the focus of further engineering be minimization of release rates from the source and location of a suitable existing facility for disposal.

Table 4. Summary of Simulated Releases to the Water Table for Unretarded Species from the Base Case and Sensitivity Cases $1-21$

\begin{tabular}{|c|c|c|c|c|}
\hline $\begin{array}{c}\text { Case } \\
\text { Number }\end{array}$ & $\begin{array}{l}\text { Case } \\
\text { Name }\end{array}$ & $\begin{array}{c}f_{\text {wet }}\left(y r^{-1}\right) \text { at } \\
10,000 \mathrm{yr}\end{array}$ & $\begin{array}{l}\text { Maximum Value } \\
\text { of } f_{w+}\left(y r^{-1}\right)\end{array}$ & $\begin{array}{c}\text { Time of } \\
\text { Max } f_{u t}(y r)\end{array}$ \\
\hline $\begin{array}{c}0 \\
\text { (Base Case) }\end{array}$ & nubasee & $4.37 e-6$ & $\begin{array}{c}6.90 e-6 \\
(4.42 e-6)\end{array}$ & $\begin{array}{c}2,150 \\
(17,500)\end{array}$ \\
\hline 1 & sensal & $4.42 e-6$ & $4.42 e-6$ & 4,400 \\
\hline 2 & sensb? & $4.37 e-6$ & $\begin{array}{c}6.90 \mathrm{e}-6 \\
(4.42 \mathrm{e}-6) \\
\end{array}$ & $\begin{array}{c}2,150 \\
(17,500)\end{array}$ \\
\hline 3 & sensb3 & $4.41 e-6$ & $4.42 \mathrm{e}-6$ & 12,000 \\
\hline 4 & sensb4 & $5.90 \mathrm{e}-8$ & $4.48 \mathrm{e}-6$ & 68,000 \\
\hline 5 & sensb5 & $4.42 \mathrm{e}-6$ & $4.42 \mathrm{e}-6$ & 600 \\
\hline 6 & sensb6 & $4.42 \mathrm{e}-6$ & $6.25 e-6$ & 2,500 \\
\hline 7 & sensb7 & $4.37 e-6$ & $4.73 e-6$ & 2,150 \\
\hline 8 & sensb8 & $4.2 e-6$ & $8.53 \mathrm{e}-6$ & 2,000 \\
\hline 9 & sensb9 & $4.29 e-6$ & $7.08 \mathrm{e}-6$ & 2,200 \\
\hline 10 & sensb10 & $4.38 \mathrm{e}-6$ & $7.29 \mathrm{e}-6$ & 2,000 \\
\hline 11 & sensbl1 & $4.38 \mathrm{e}-6$ & $6.90 \mathrm{e}-6$ & 2,150 \\
\hline 12 & sensb12 & $4.37 e-6$ & $6.90 \mathrm{e}-6$ & 2,150 \\
\hline 13 & sensa13 & $4.37 e-6$ & $7.29 e-6$ & 2,200 \\
\hline 14 & sensbl4 & $4.37 e-6$ & $6.84 e-6$ & 2,150 \\
\hline 15 & sensb15 & $4.37 e-6$ & $5.72 \mathrm{e}-6$ & 2,200 \\
\hline 16 & sensb16 & $4.37 e-6$ & $6.91 \mathrm{e}-6$ & 2,150 \\
\hline 17 & sensb17 & $4.37 e-6$ & $5.89 e-6$ & 1,990 \\
\hline 18 & sensbl8 & $4.37 e-6$ & $8.01 \mathrm{e}-6$ & 2,270 \\
\hline 19 & sensa 19 & $4.37 e-6$ & $10.2 e-6$ & 2,350 \\
\hline 20 & sensb20 & $8 e-8$ & $3.99 e-6$ & 100,000 \\
\hline 21 & sensb21 & $4.26 \mathrm{e}-6$ & $6.87 \mathrm{e}-6$ & 2,150 \\
\hline
\end{tabular}


WHC-SD-WM-RPT-225, Rev. 0

Table 5. Summary of Simulated Releases to the Water Table for Sensitivity Case 22 (sensb22)

\begin{tabular}{|c|c|c|c|}
\hline Species & $\begin{array}{l}f_{\text {ht }}\left(y^{-1}\right) \text { at } \\
10,000 \text { years }\end{array}$ & $\begin{array}{l}\text { Maximum Value } \\
\text { of } f_{w+}\left(y r^{-1}\right)\end{array}$ & $\begin{array}{c}\text { Time of } \\
\operatorname{Max} f(y r)\end{array}$ \\
\hline Se-79 & $7.67 \mathrm{e}-7$ & $7.674 \mathrm{e}-7$ & 9,700 \\
\hline Tc-99 & $4.7 e-7$ & $5.02 \mathrm{e}-7$ & 14,600 \\
\hline $\begin{array}{l}\text { Tc-99, with no } \\
\text { Na ion exchange }\end{array}$ & $1.9 e-8$ & $2.8 \mathrm{e}-8$ & 18,200 \\
\hline $\begin{array}{c}\text { Tc-99, increased } \\
\text { pore velocity }\end{array}$ & $1.08 \mathrm{e}-6$ & $1.38 \mathrm{e}-6$ & 18,000 \\
\hline $\mathbf{U}($ Total) & $2.86 e^{-7}$ & $5.91 \mathrm{e}-7$ & 22,000 \\
\hline I-129 & $1.37 e-10$ & $3.44 \mathrm{e}-7$ & 60,000 \\
\hline $\mathrm{Np}-237^{a}$ & $9.3 e-17$ & $2.32 e-5$ & $100,000^{\mathrm{b}}$ \\
\hline Pu (Total) & 0.0 & $2.72 \mathrm{e}-11$ & $100,000^{\mathrm{b}}$ \\
\hline
\end{tabular}

${ }^{a}$ Simulated neptunium source strength is inaccurate (McGrail 1996).

bimulation stops at 100,000 years after time of disposal.

\subsection{REFERENCES}

Amtec, 1993, "Tecplot Version 6 User's Manua1", V6.0/93-98, Amtec Engineering, Inc., Bellevue, Washington.

Arfken, G., 1970, Mathematical Methods for Physicists, Academic Press, New York, New York.

Chen, Y., D. W. Engel, B. P. McGrail, and K. S. Lessor, 1995, "AREST-CT V1.0 Software Verification", PNL-10692, Pacific Northwest National Laboratory, Richland, Washington.

Eyler, L. L. and M. J. Budden, 1984, "Verification and Benchmarking of Porflo: An Equivalent Porous Continuum Code for Repository Scale Analysis", PNL5044, Pacific Northwest National Laboratory, Richland, Washington.

Kline, N. W., A. K. Runchal, and R. G. Baca, 1983, "PORFLo Computer Code: Users Guide", RHO-BW-CR-138 P, Rockwell Hanford Operations, Richland, Washington.

Kline, N. W., 1995, "Development of a Unit Cell Model for Interim Performance Assessment of Vitrified Low Level Waste Disposal", WHC-SD-WM-RPT-189, Rev. 0, Westinghouse Hanford Company, Richland, Washington.

Mann, F. M., C. R. Eiholzer, N. W. Kline, B. P. McGrail, and M. G. Piepho, 1995a, "Impacts of Disposal System Design Options on Low-Level Glass Waste Disposal System Performance", WHC-EP-0810, Rev. 1, Westinghouse Hanford Company, Richland, Washington. 
WHC-SD-WM-RPT-225, Rev. 0

Mann, F. M., C. R. Eiholzer, R. Khaleel, N. W. Kline, A. H. Lu, B. P. McGrail, P. D. Rittman, and F. A. Schmittroth, 1995b, "Definition of the Base Analysis Case of the Interim Performance Assessment", WHC-SD-WM-RPT-200, Rev. 0, Westinghouse Hanford Company, Richland, Washington.

Mann, F. M., 1996, "INTEG: A Program to Calculate Groundwater Contamination and Human Doses", WHC-SD-WM-RPT-219, West inghouse Hanford Company, Richland, Washington.

McGrail, B. P., 1996, "AREST-CT Simulation Results", Correspondence from Pete McGrail to Niall Kline dated May 8, 1996.

Piepho, M. G., W. H. Sutherland, and P. D. Rittman, 1994, "The Grout/Glass Performance Assessment Code System (GPACS) with Verification and Benchmarking", WHC-SD-WM-UM-019, Rev. 0, Westinghouse Hanford Company, Richland, Washington.

Piepho, M., 1996, "Low-Level-Vitrification-Waste Performance Assessment Flow and Transport Modeling", Letter Number DBSA-PNWB-96-42, Daniel B. Stephens \& Associates, Inc., Pacific Northwest Branch, Richland, Washington.

Runchal, A. K. and B. Sagar, 1992, "PORFLOW: A Model for Fluid Flow, Heat and Mass Transport in Multifluid, Multiphase Fractured Porous Media. User's Manual - Version 2.40", ACRi/016/Rev. G, Analytic and Computational Research, Inc., Bel Air, California. 
Figure 1. Schematic Diagram of Base Case Unit Cell Model.

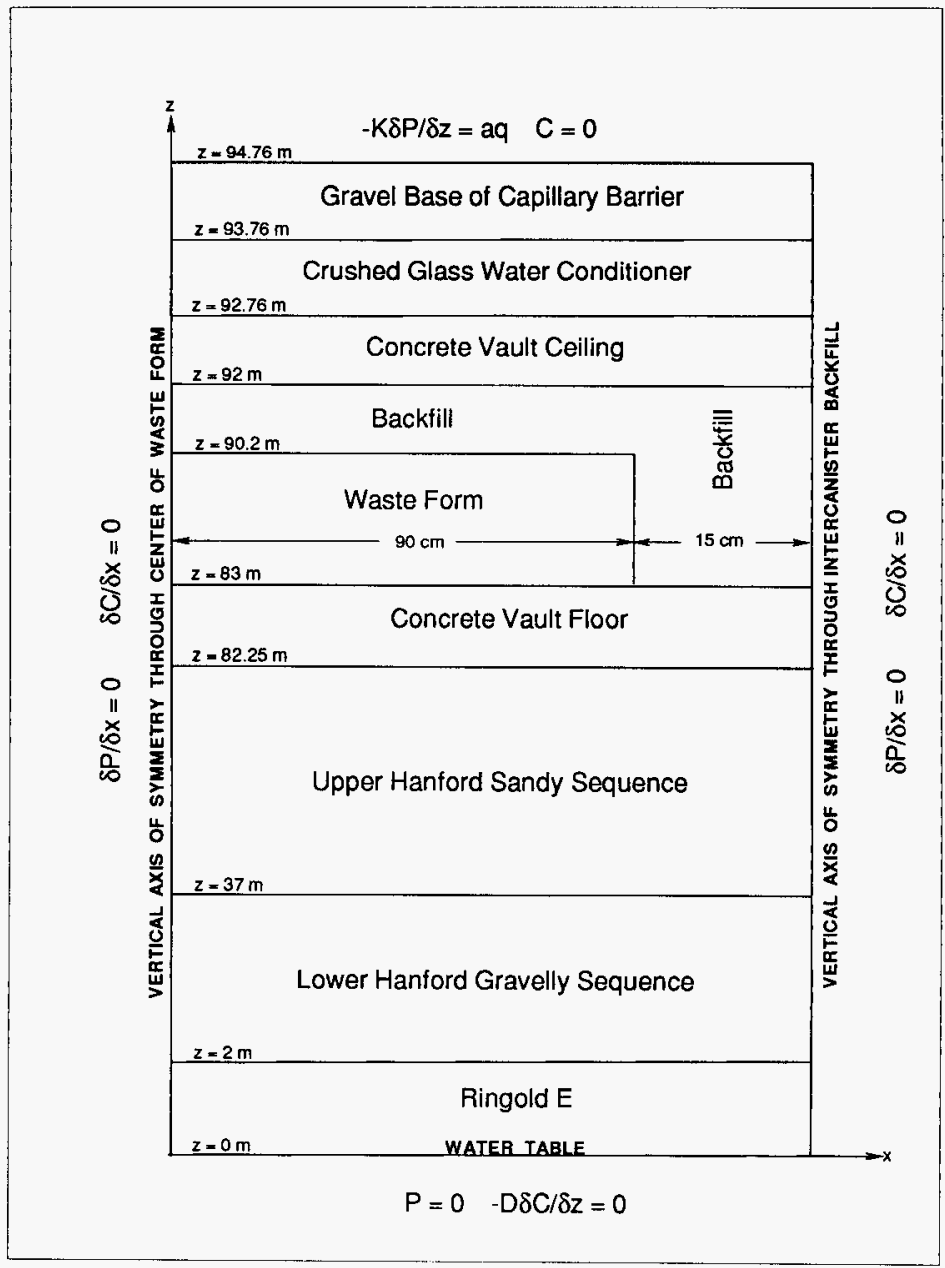


Figure 2. Schematic Diagram of Modified Unit Cell Model.

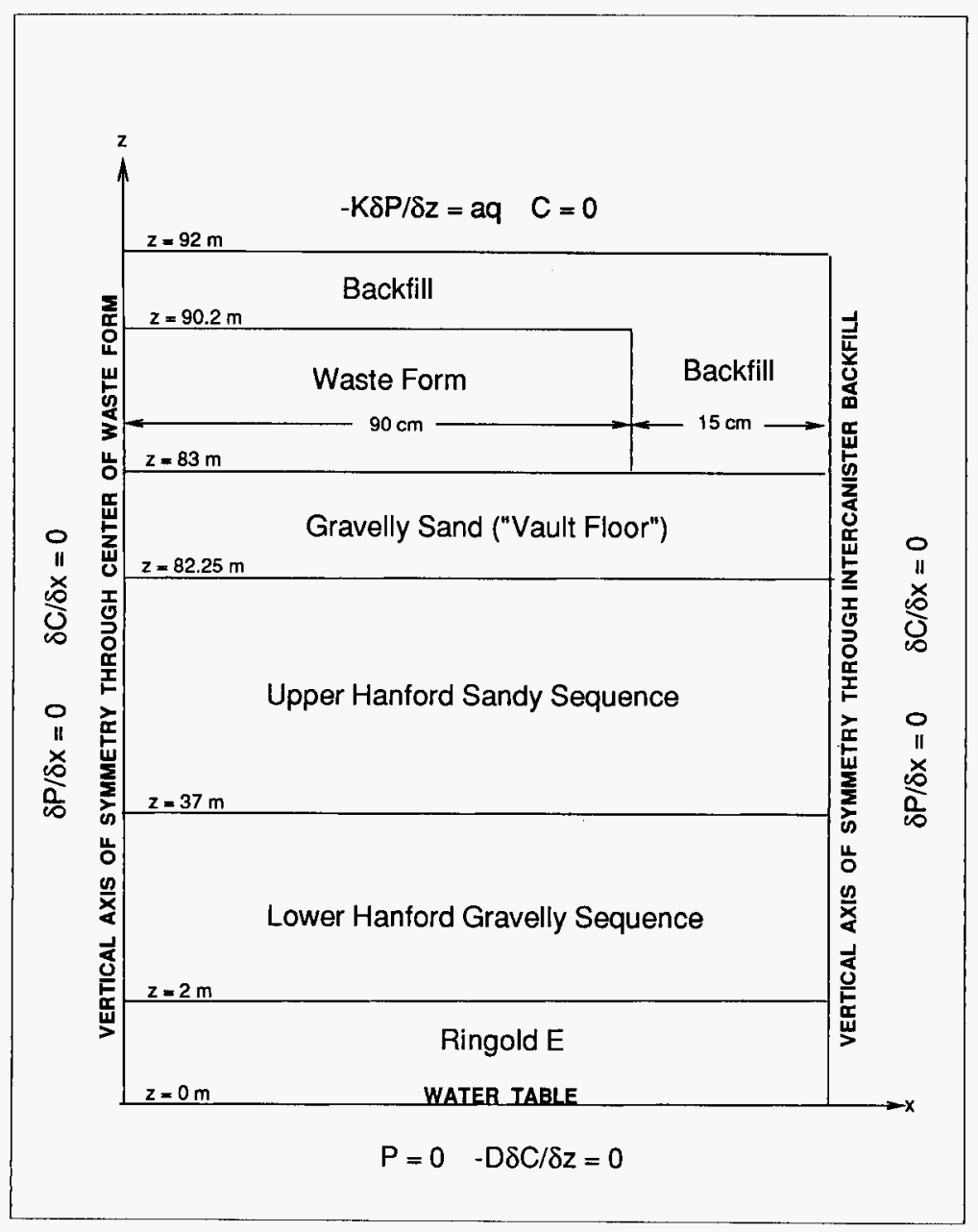




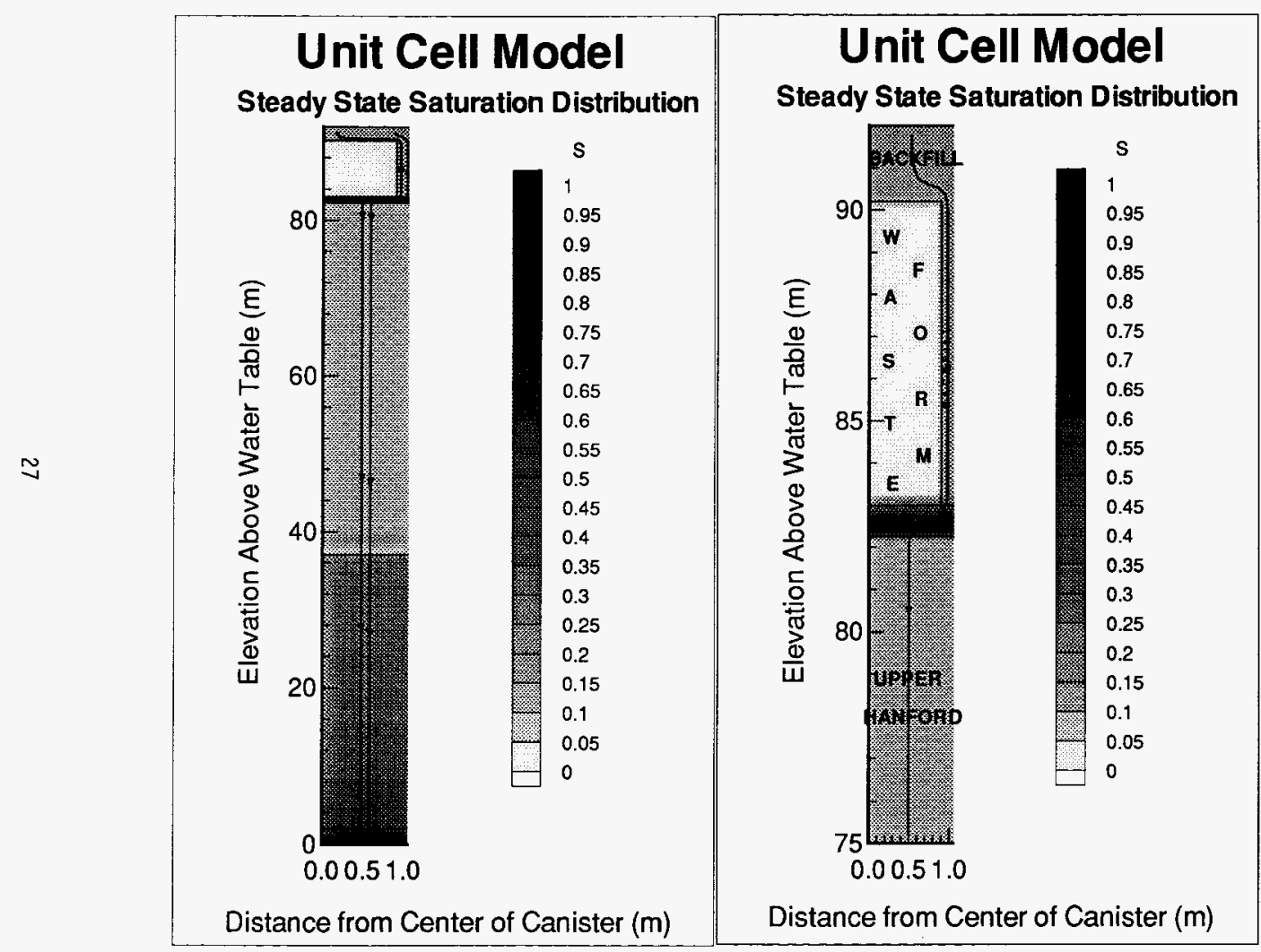

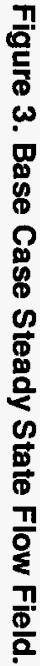


WHC-SD-WM-RPT-225, Rev. 0

Figure 4. Mesh Plot with Streamlines.

Time Between Markers $=5000$ years .

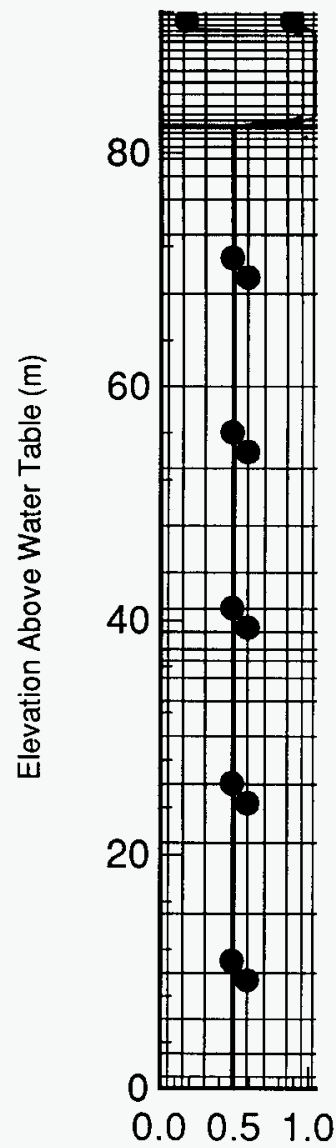

Distance from Center of Canister (m) 
Figure 5. Base Case Time History of Instantaneous Fluid Flux.

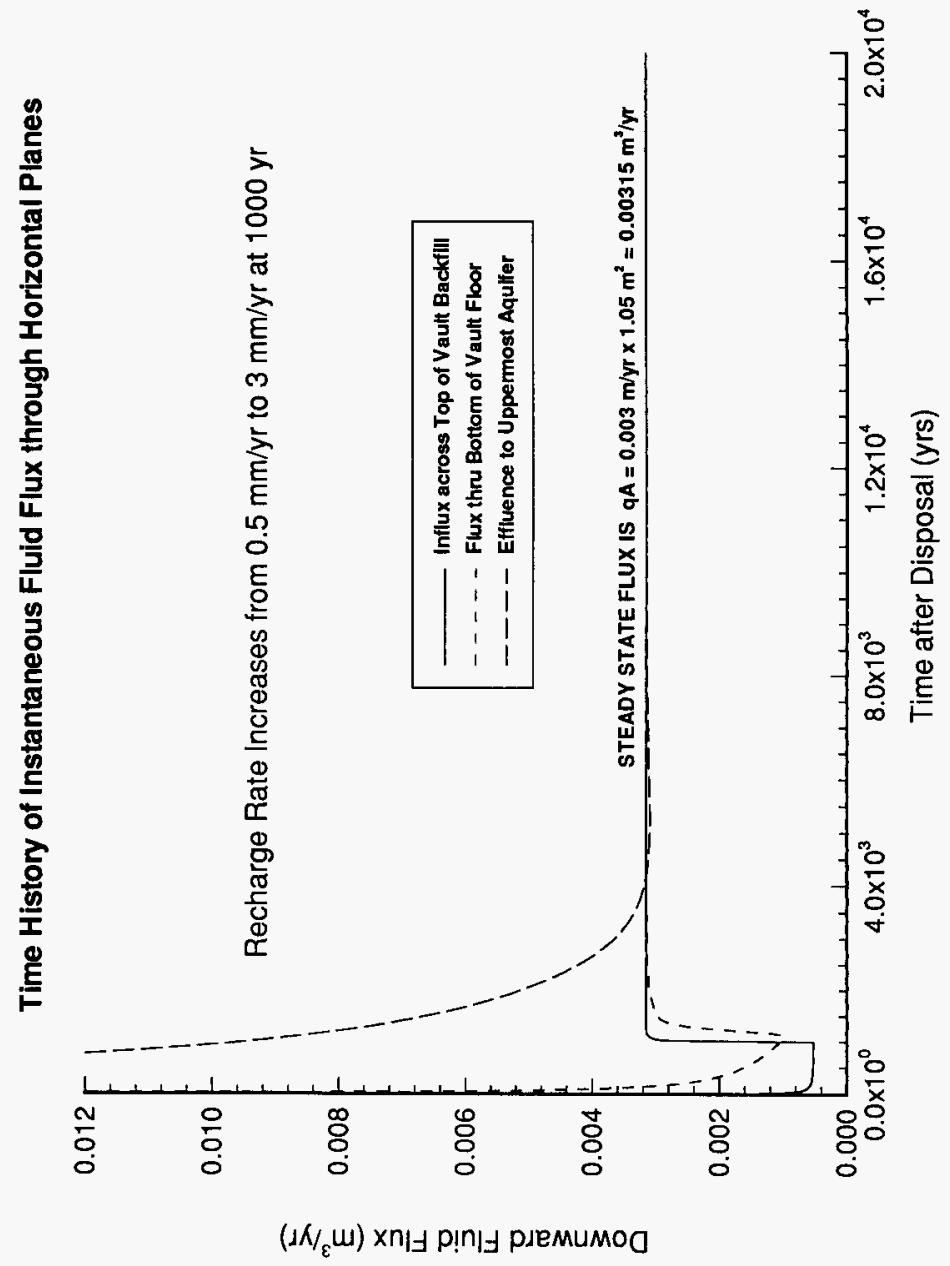


WHC-SD-WM-RPT-225, Rev. 0

Figure 6. Computation of Fractional Release Rate from the Vault Floor.
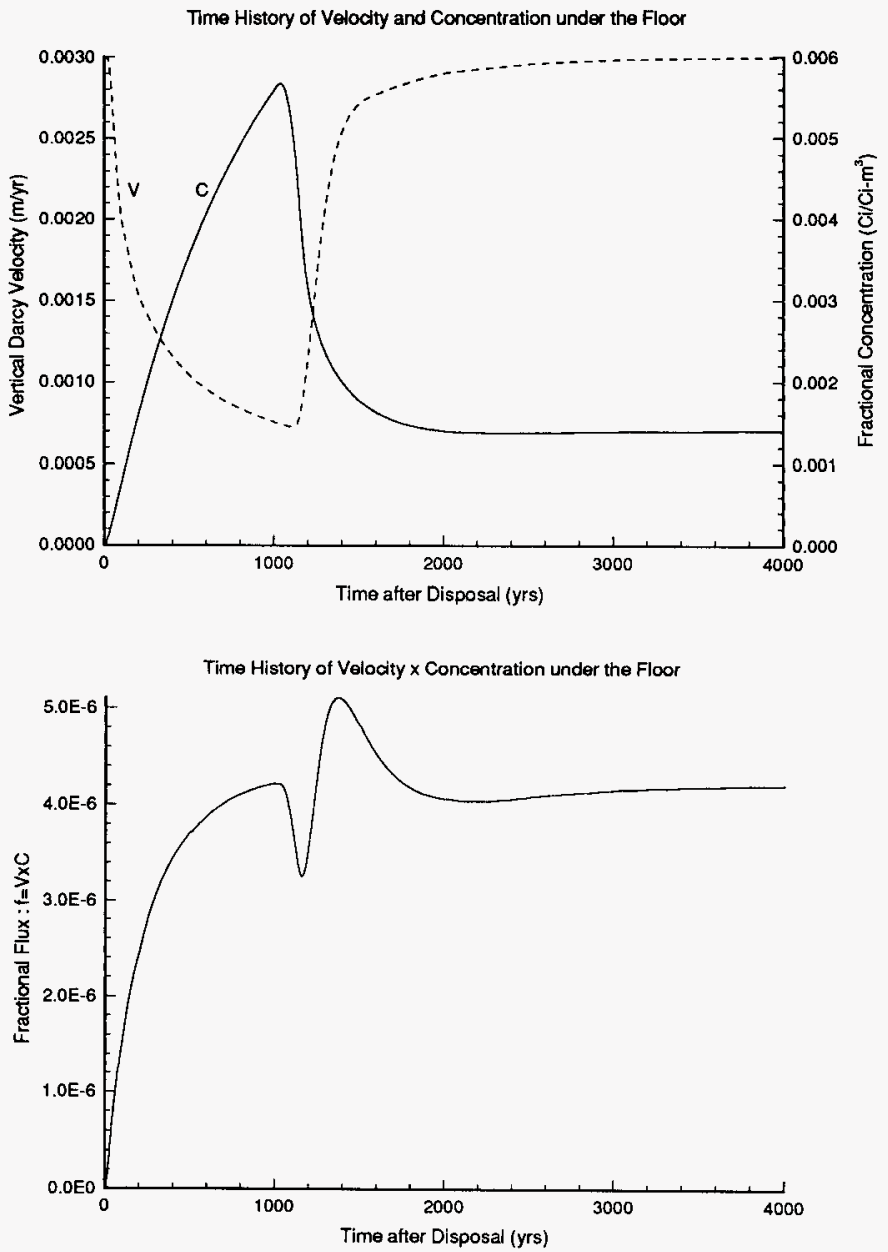
Figure 7. Simulated Fractional Release Rates for The Base Case.
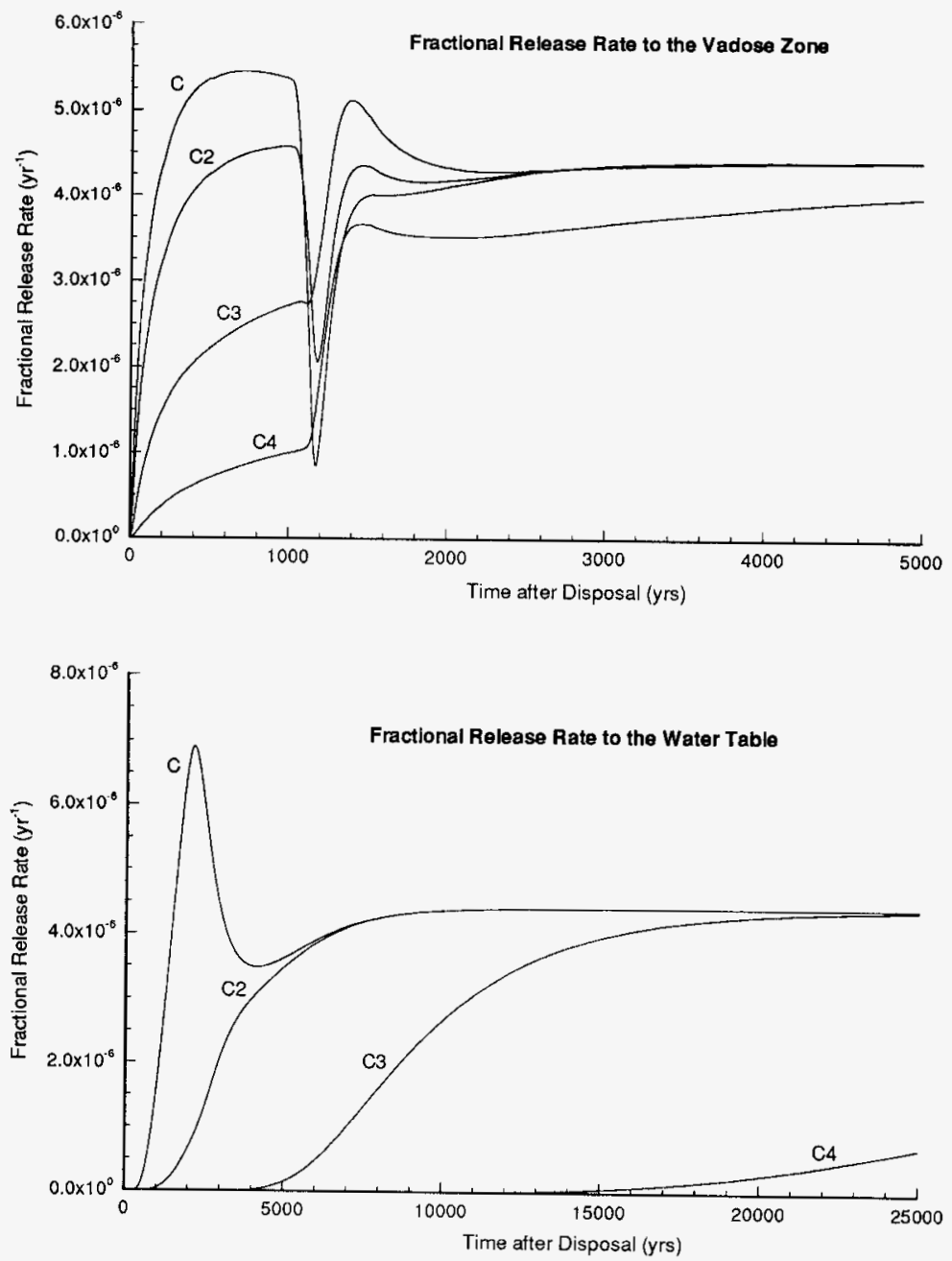
Figure 8. Simulated Fractional Release Rates for Sensitivity Case 1.
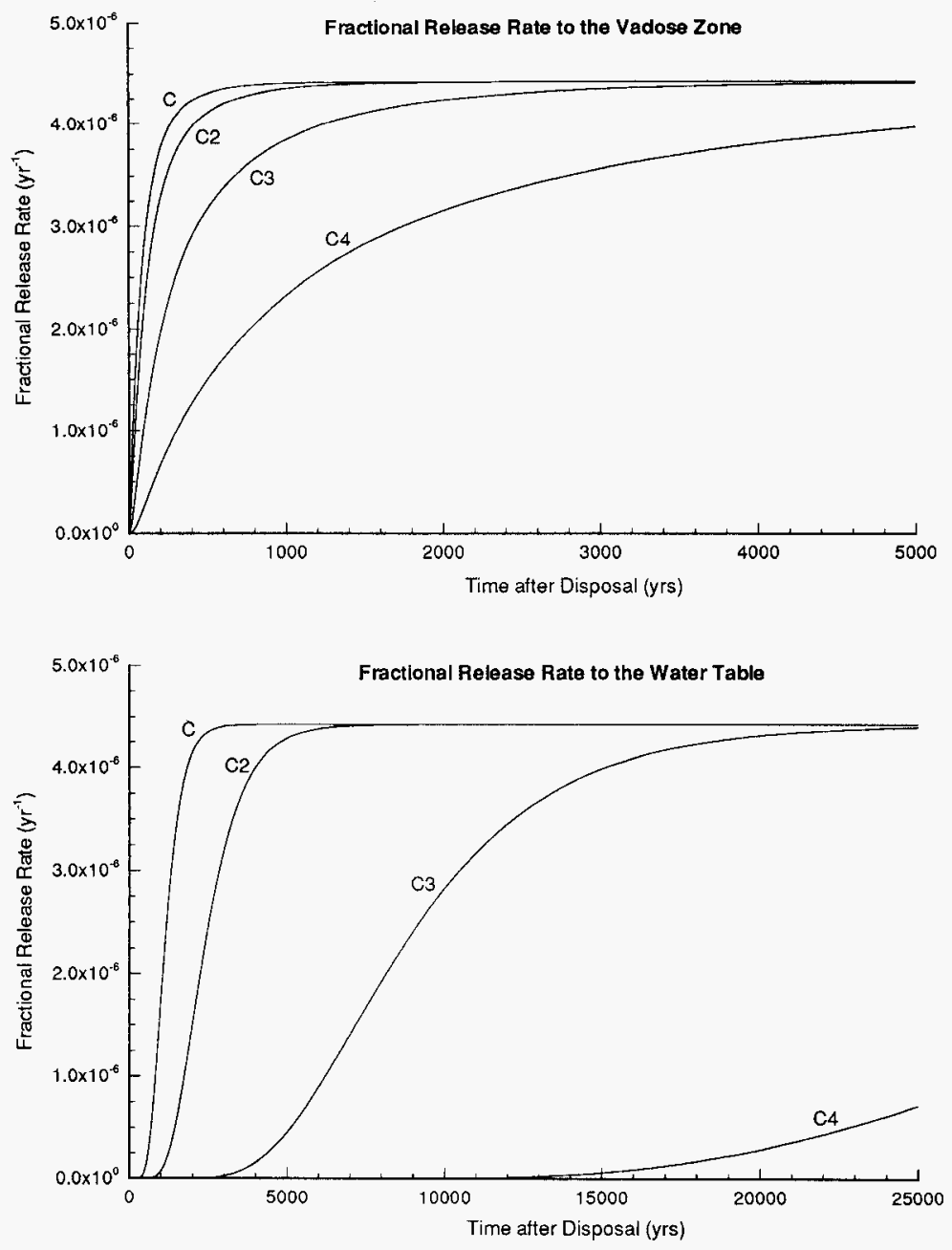
Figure 9. Simulated Fractional Release Rates for Sensitivity Case 2.
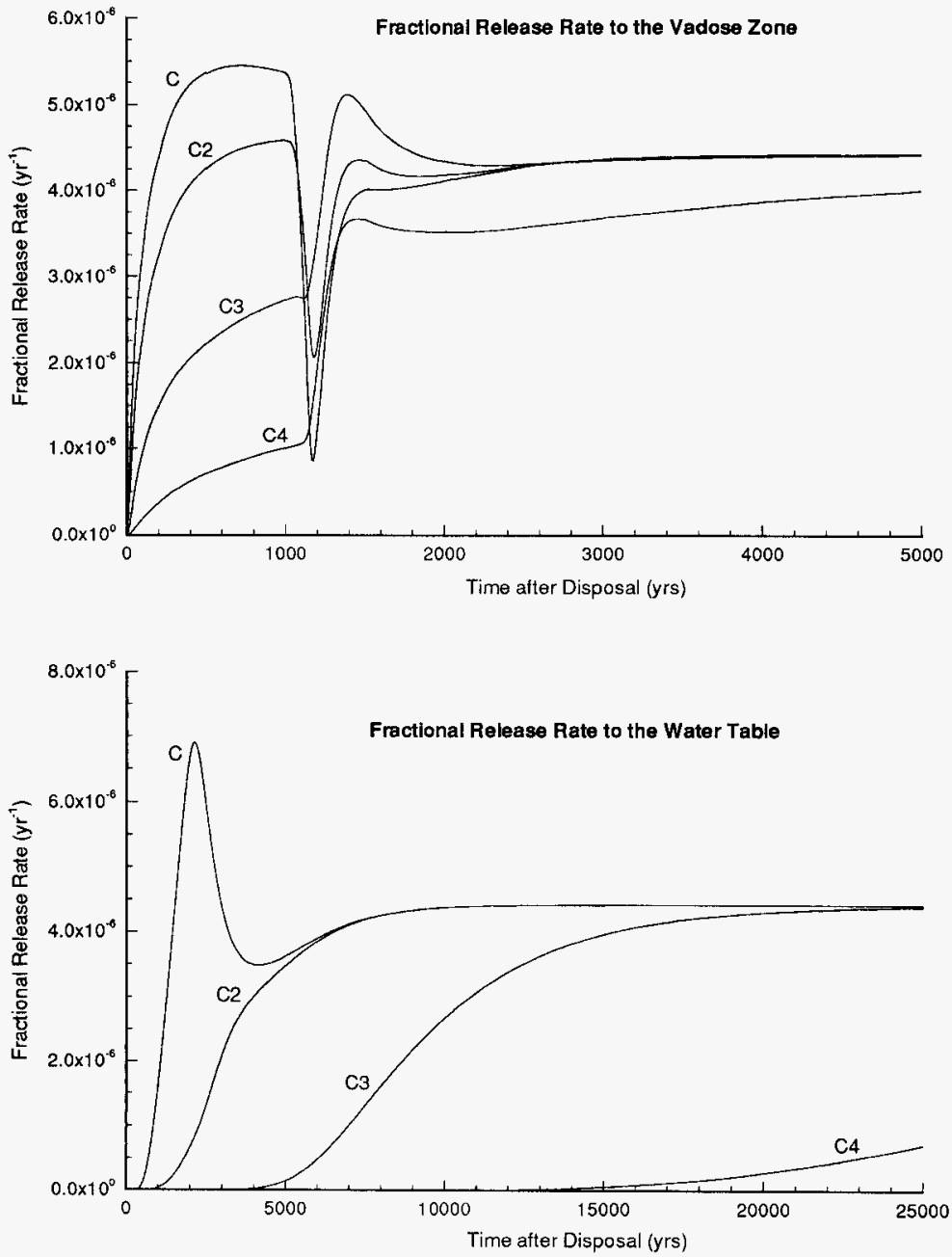
Figure 10. Simulated Fractional Release Rates for Sensitivity Case 3.
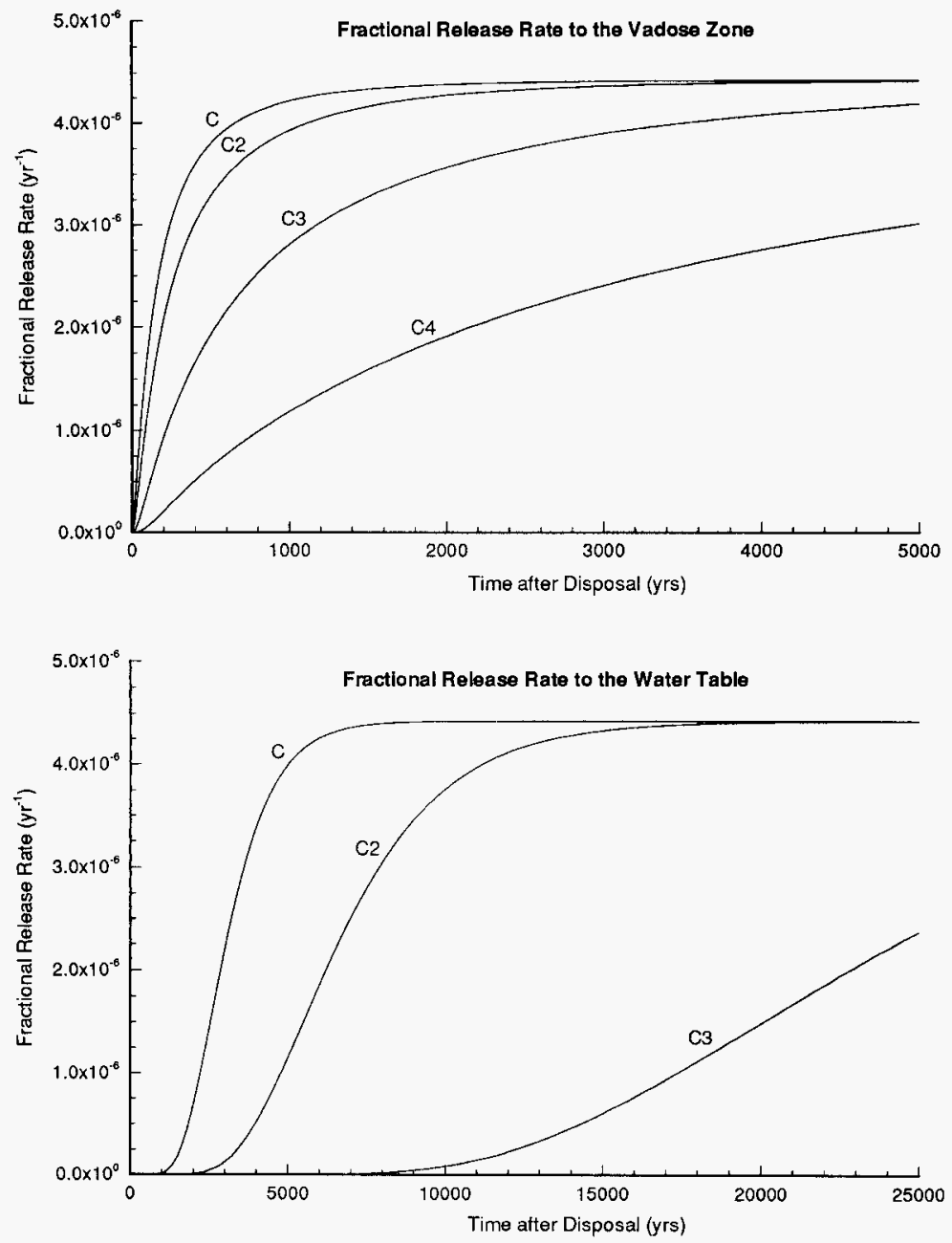
Figure 11. Simulated Fractional Release Rates for Sensitivity Case 4.
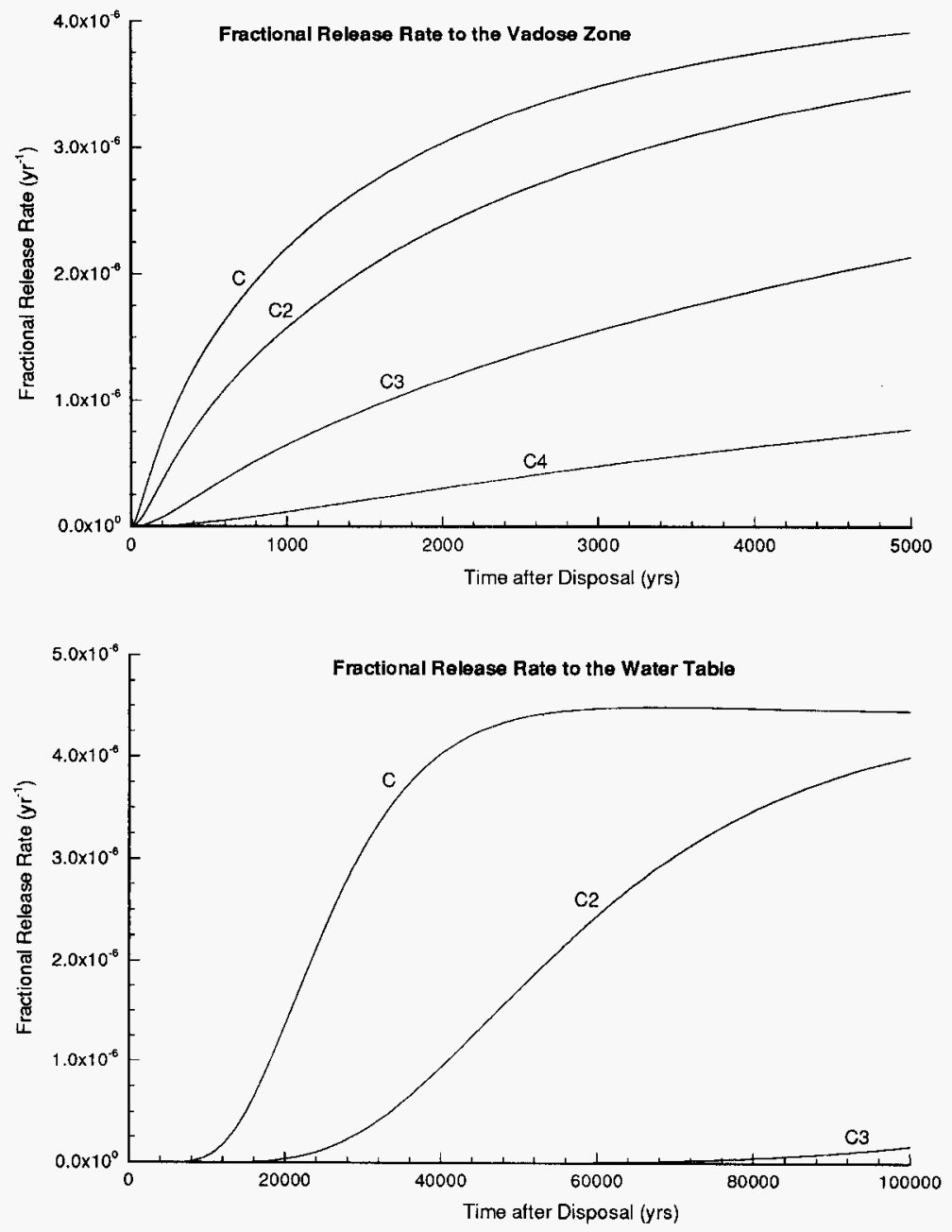
Figure 12a. Simulated Fractional Release Rates for Sensitivity Case 5.
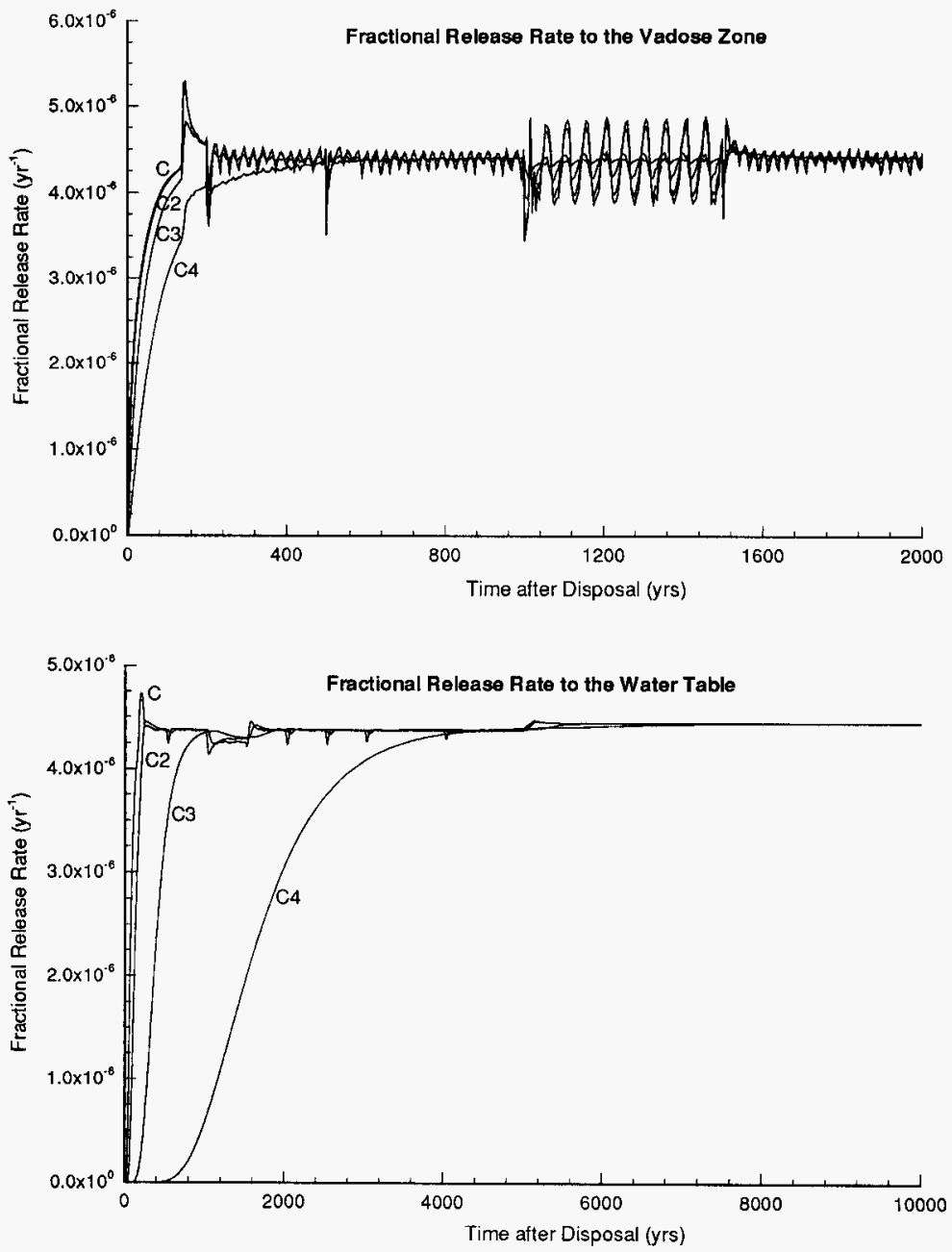
Figure 12b. Simulated Fractional Release Rates for Sensitivity Case 5 with Extended Preconditioning.
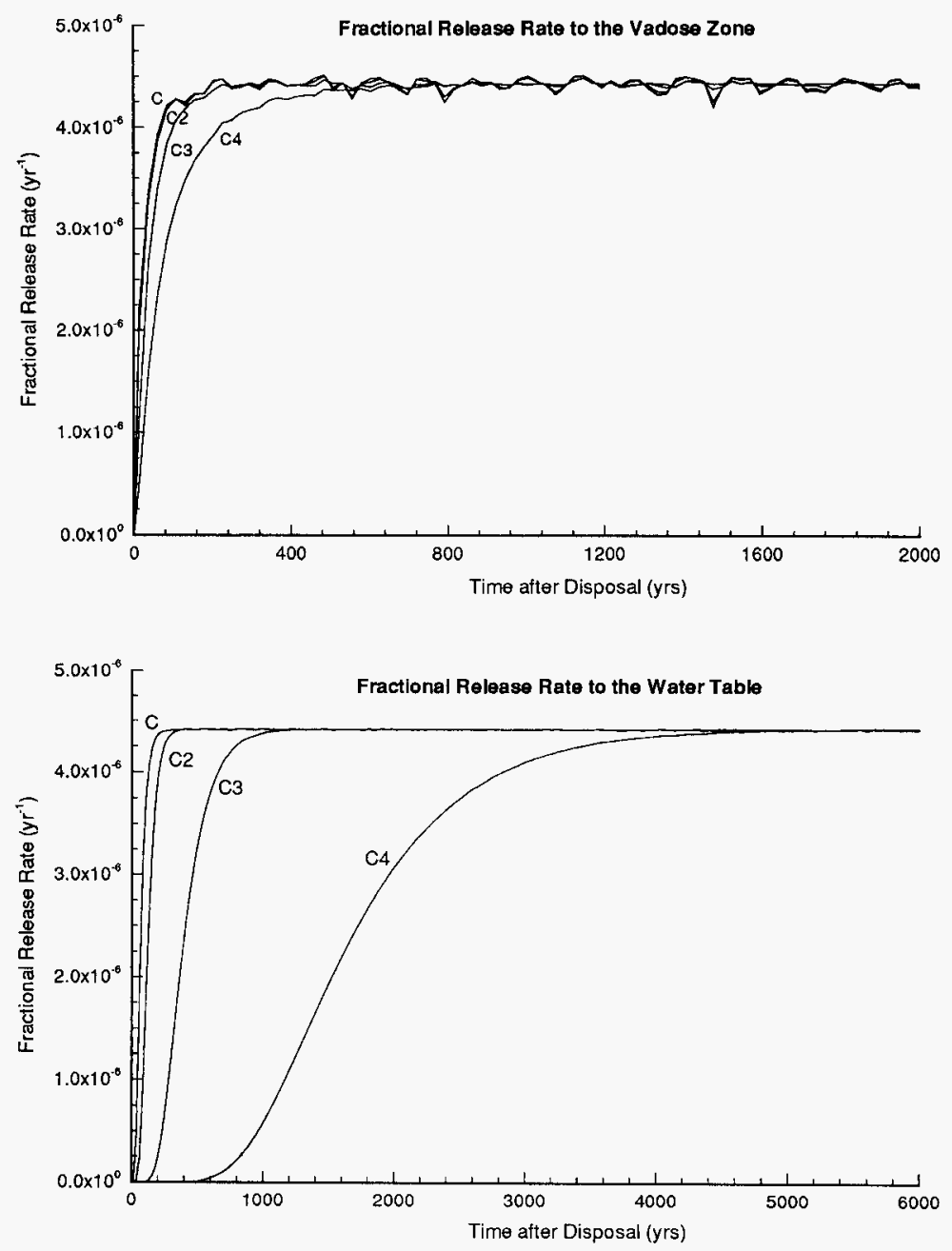
Figure 13. Simulated Fractional Release Rates for Sensitivity Case 6.
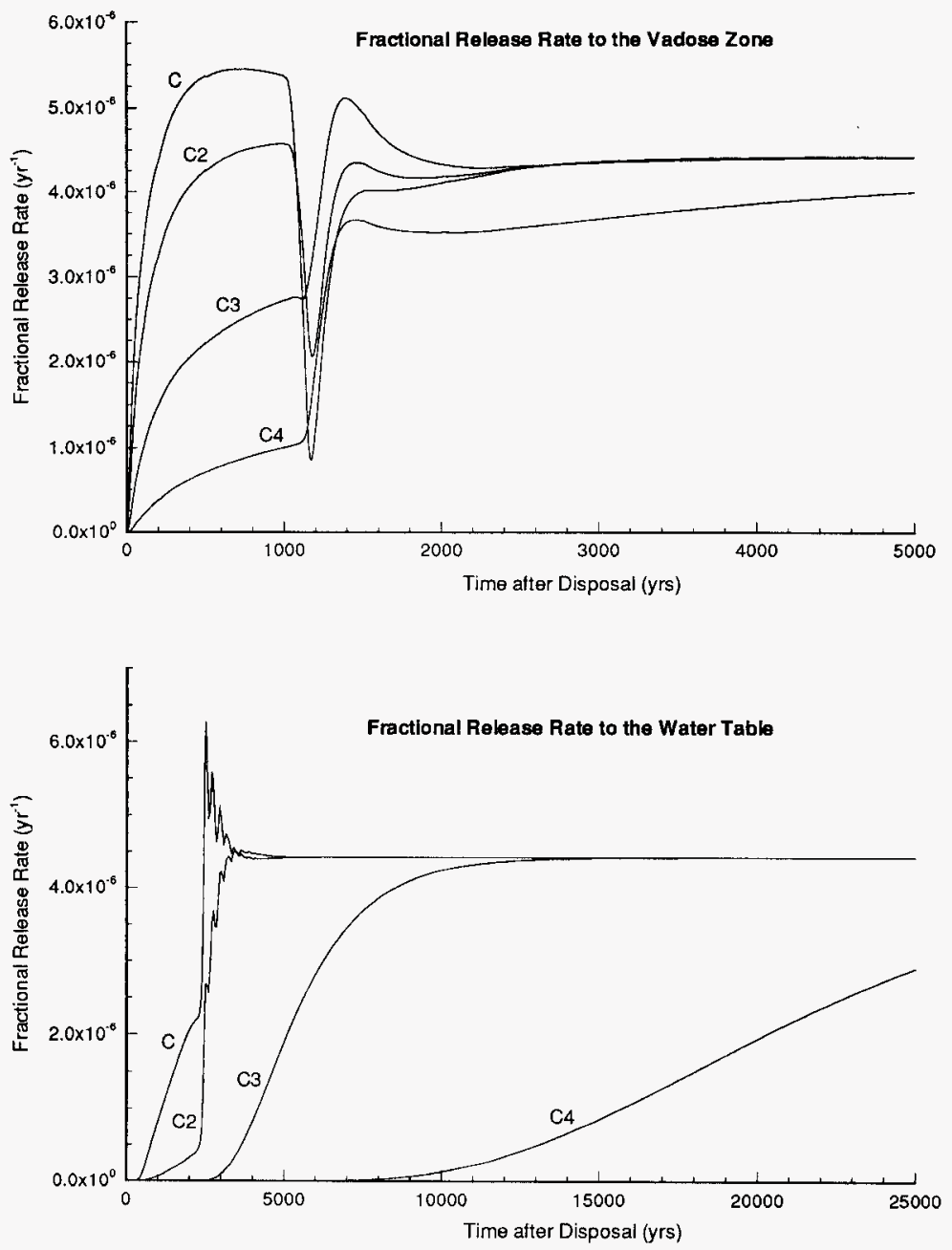
Flgure 14. Simulated Fractional Release Rates for Sensitivity Case 7.
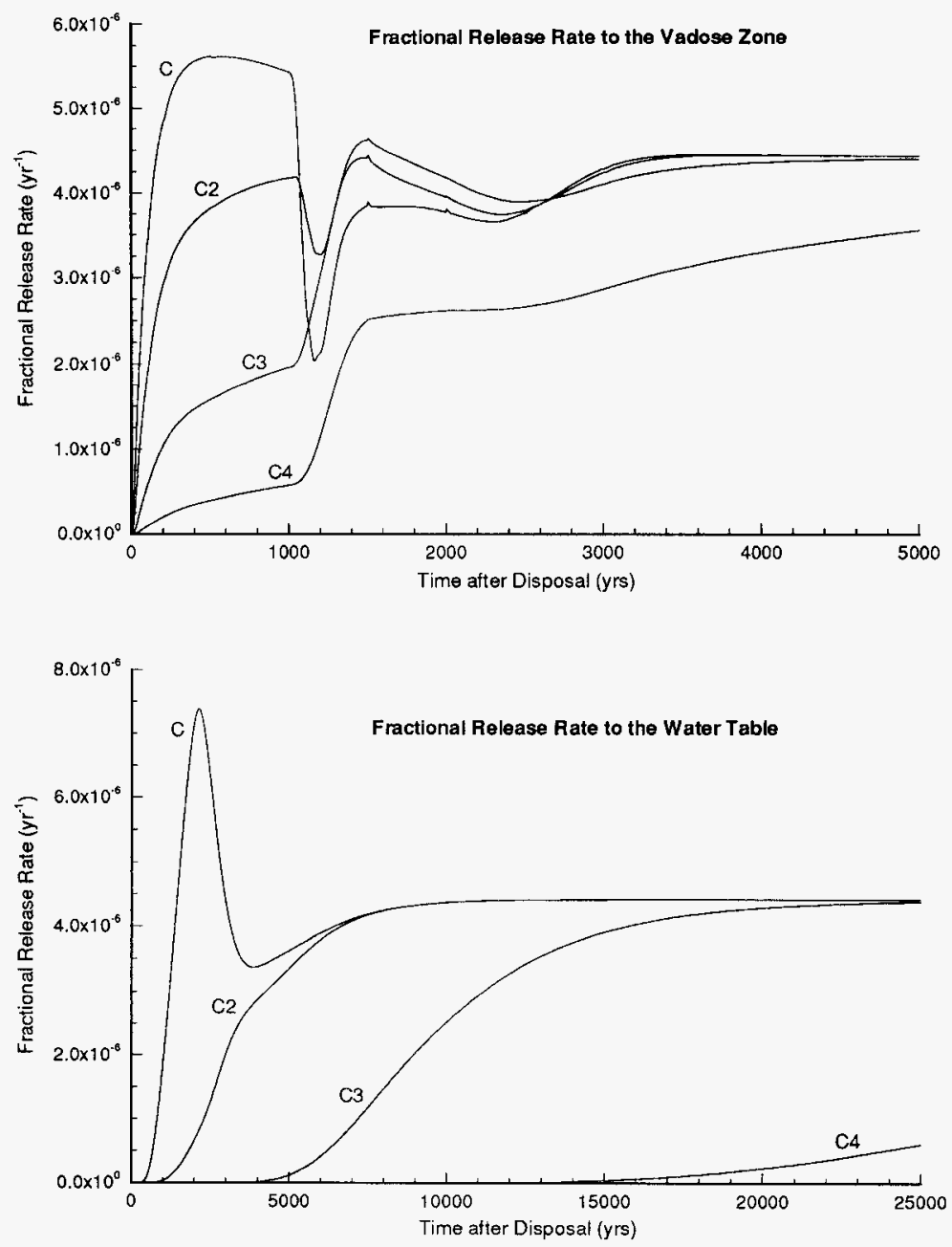
Figure 15. Simulated Fractional Release Rates for Sensitivity Case 8.
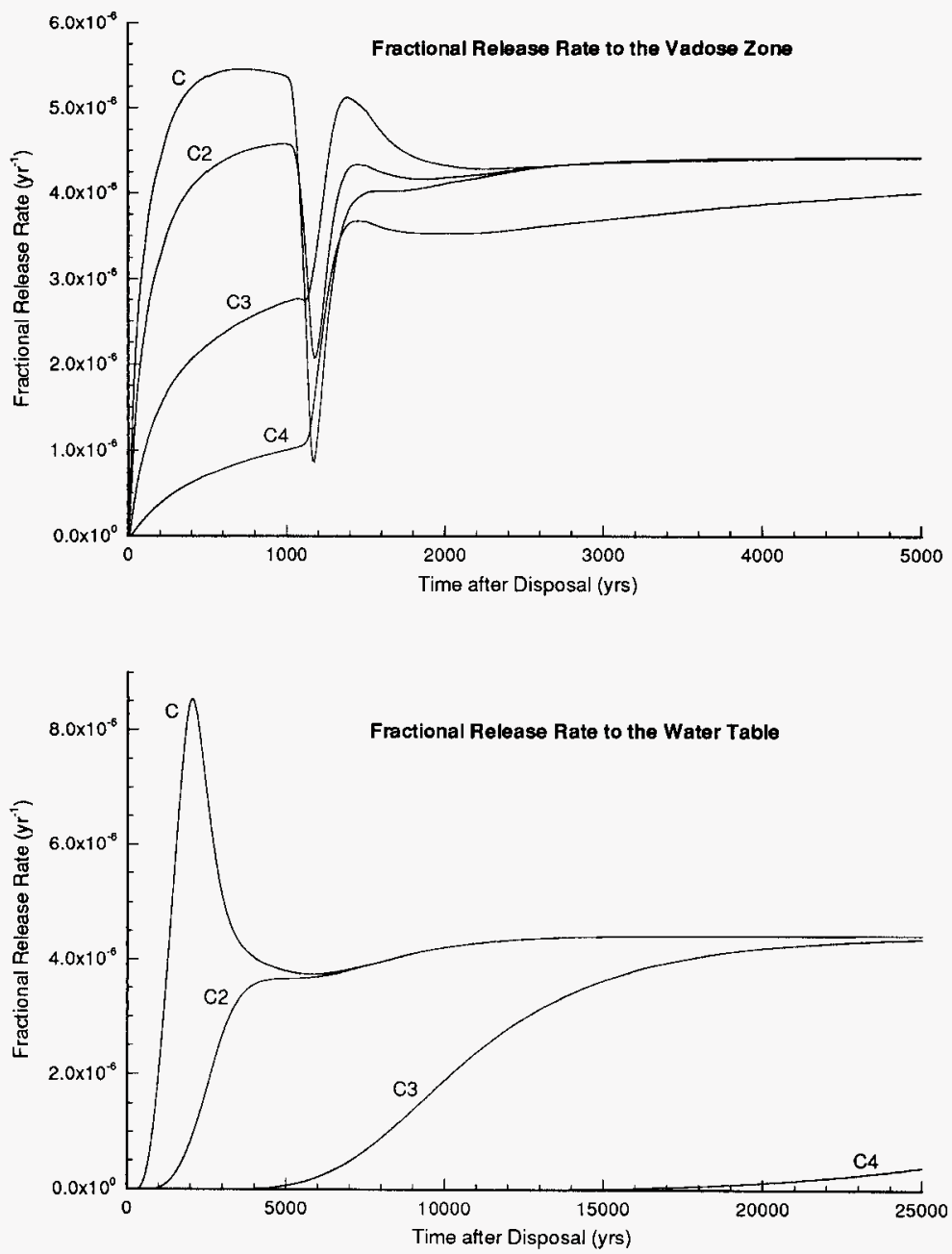
Figure 16. Simulated Fractional Release Rates for Sensitivity Case 9.
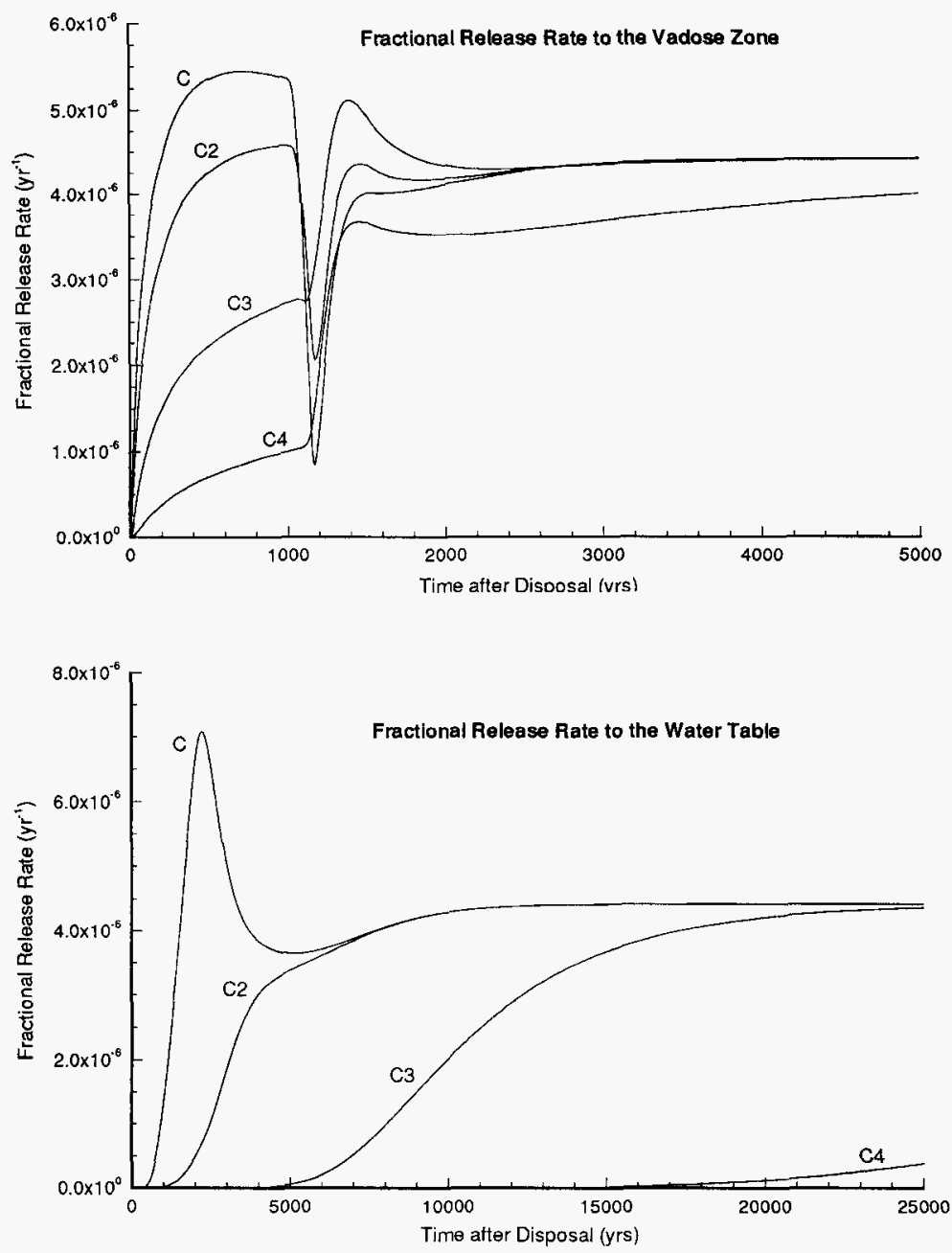
Figure 17. Simulated Fractional Release Rates for Sensitivity Case 10.
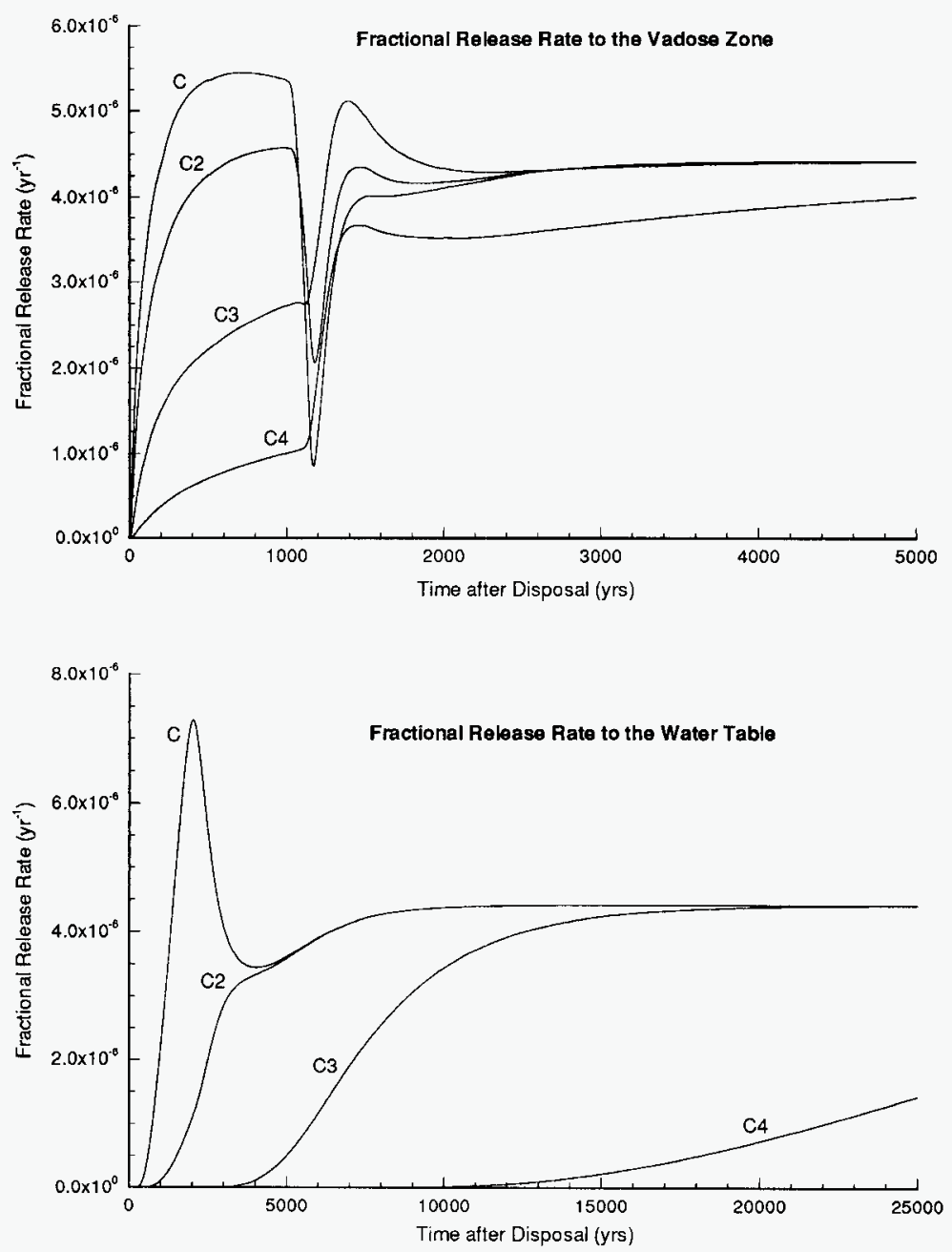
WHC-SD-WM-RPT-225, Rev. 0

Figure 18. Simulated Fractional Release Rates for Sensitivity Case 11.
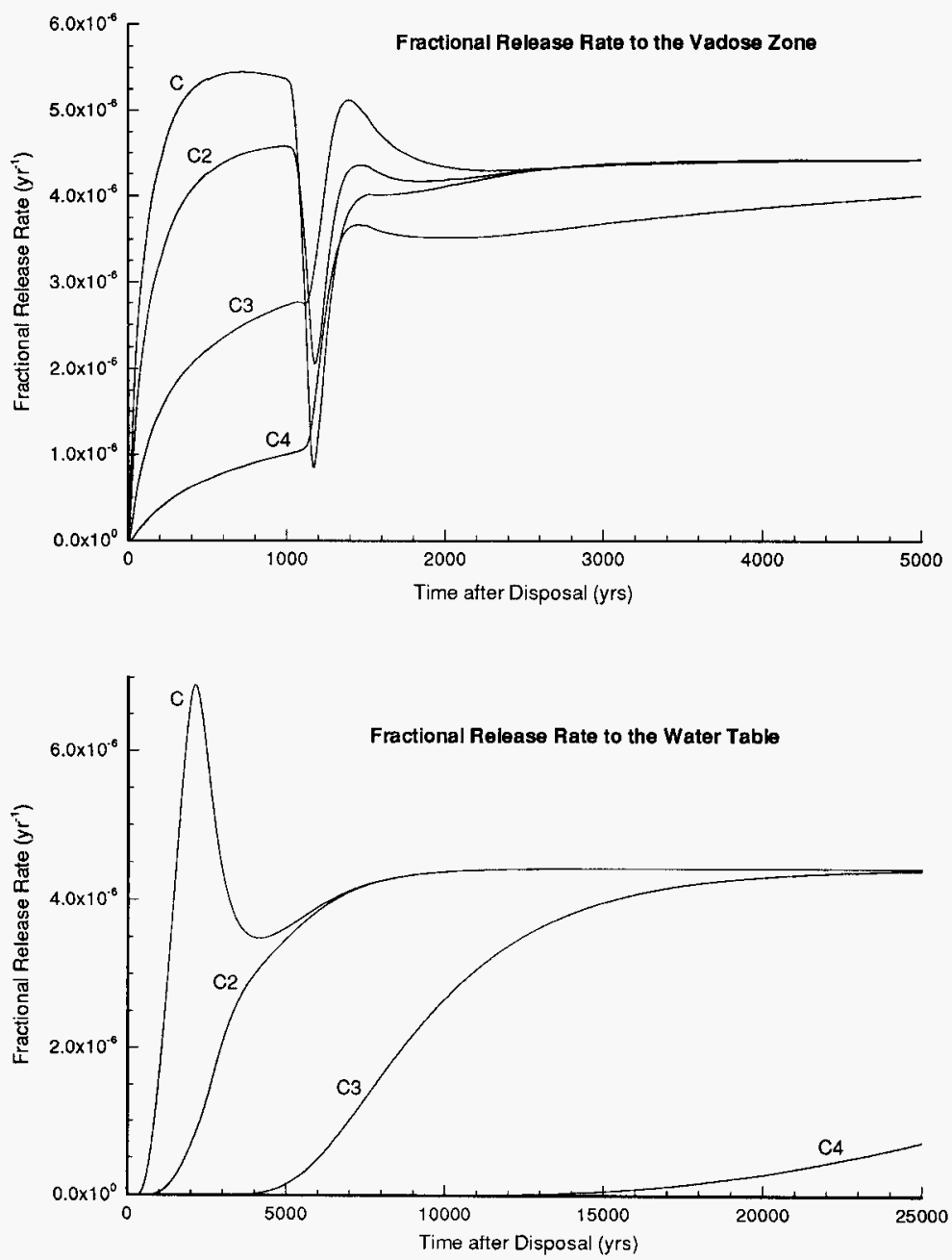
Figure 19. Simulated Fractional Release Rates for Sensitivity Case 12.
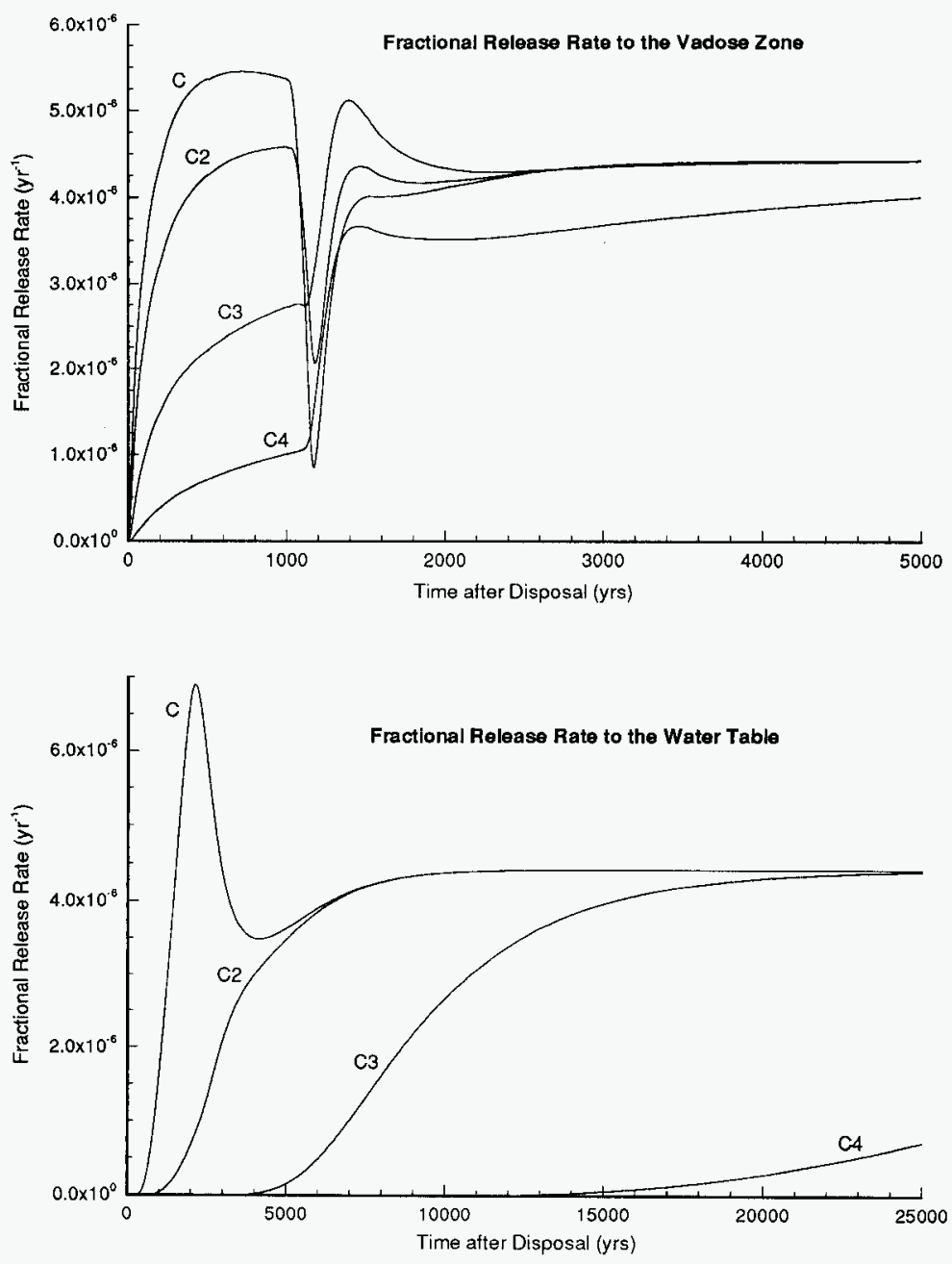
WHC-SD-WM-RPT-225, Rev. 0

Figure 20. Simulated Fractional Release Rates for Sensitivity Case 13.
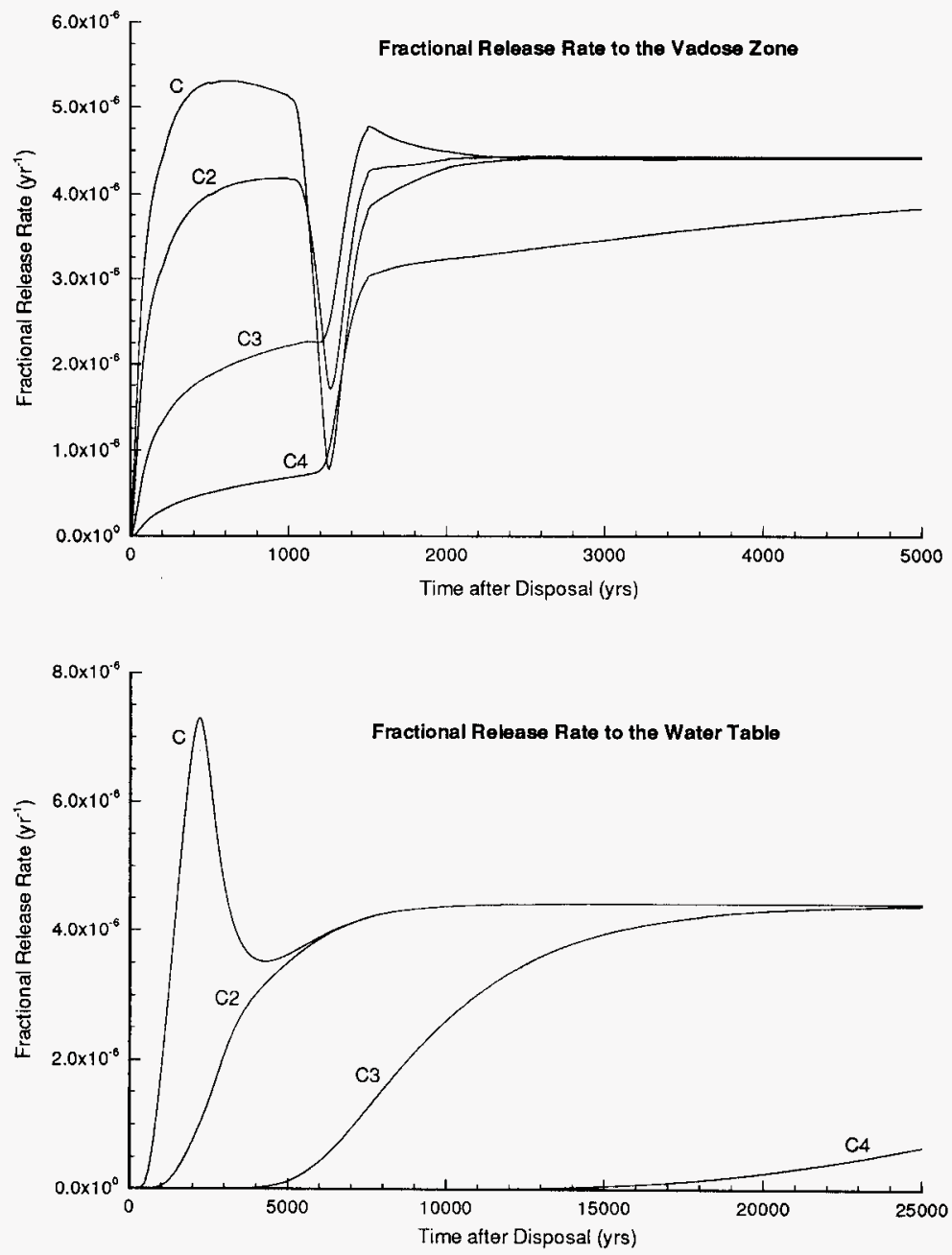
Figure 21. Simulated Fractional Release Rates for Sensitivity Case 14.
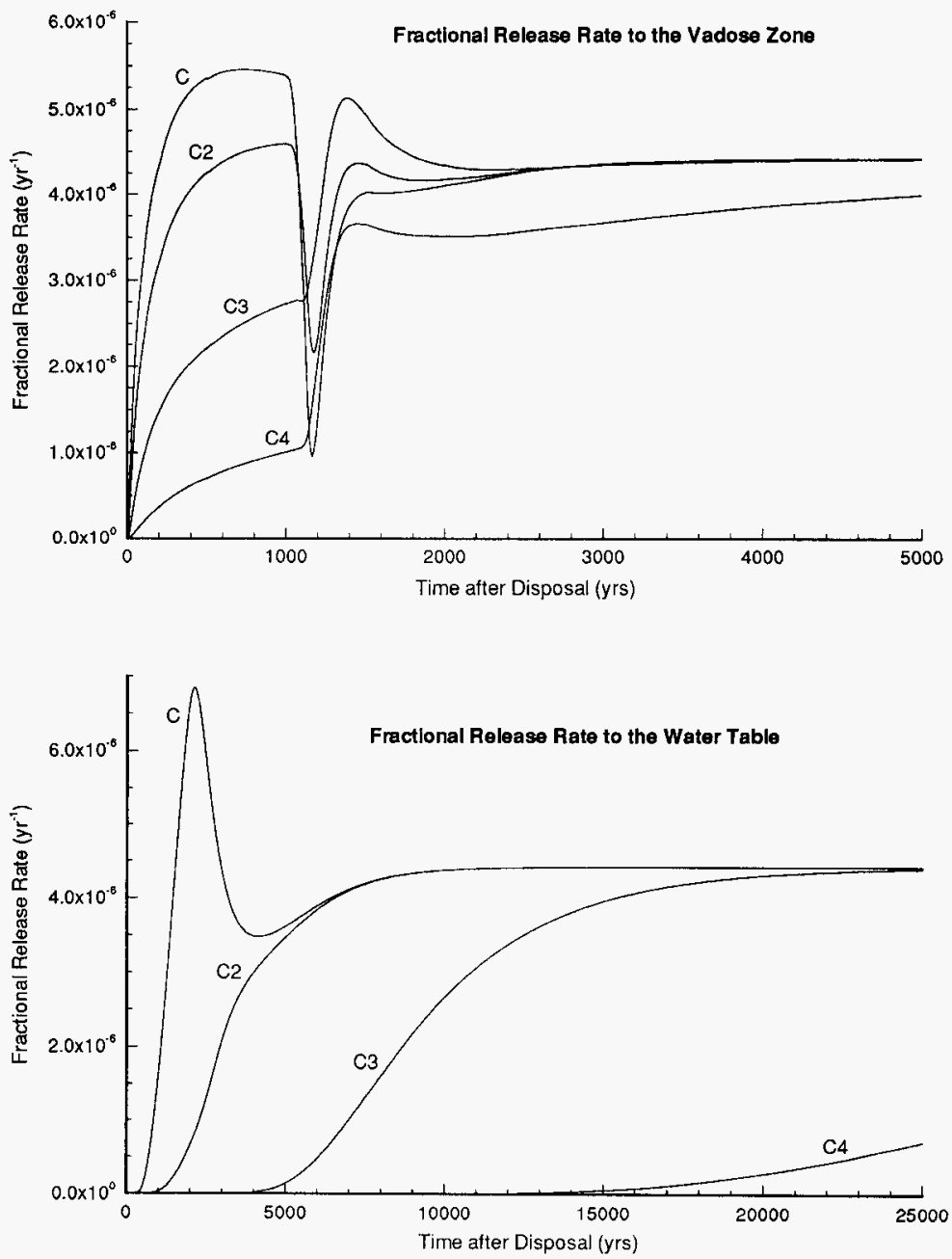
Figure 22. Simulated Fractional Release Rates for Sensitivity Case 15.
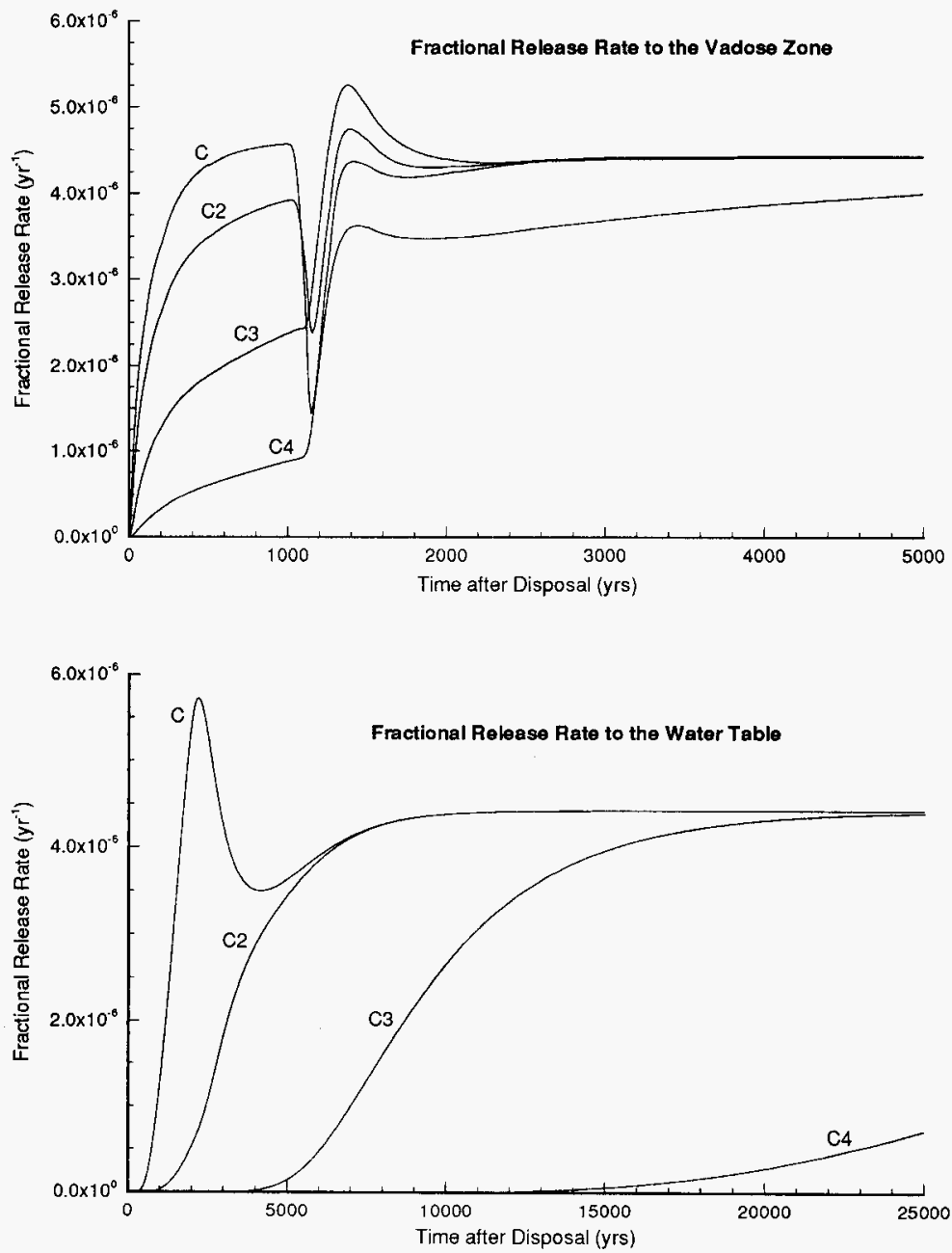
Figure 23. Simulated Fractional Release Rates for Sensitivity Case 16.
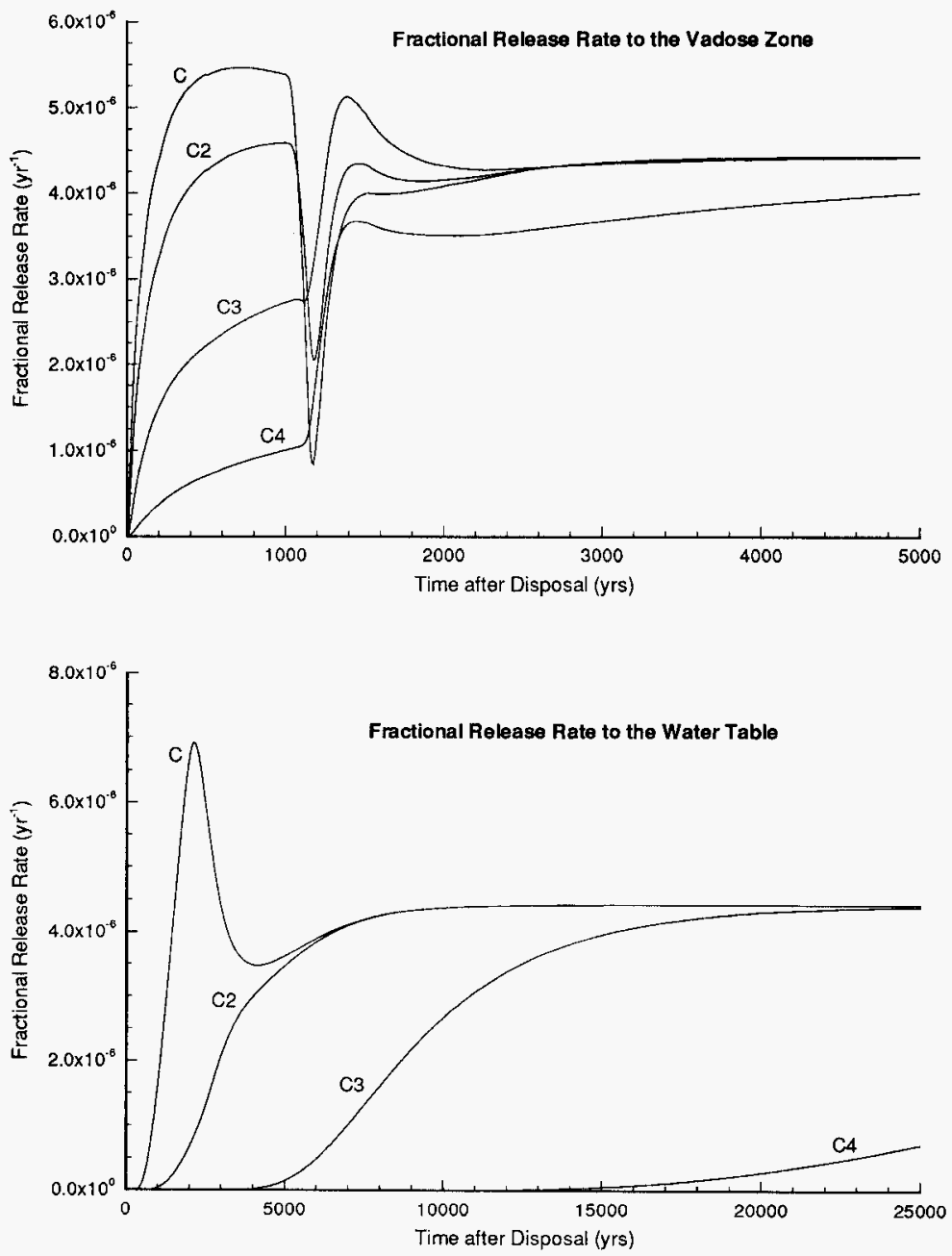
Figure 24. Simulated Fractional Release Rates for Sensitivity Case 17.
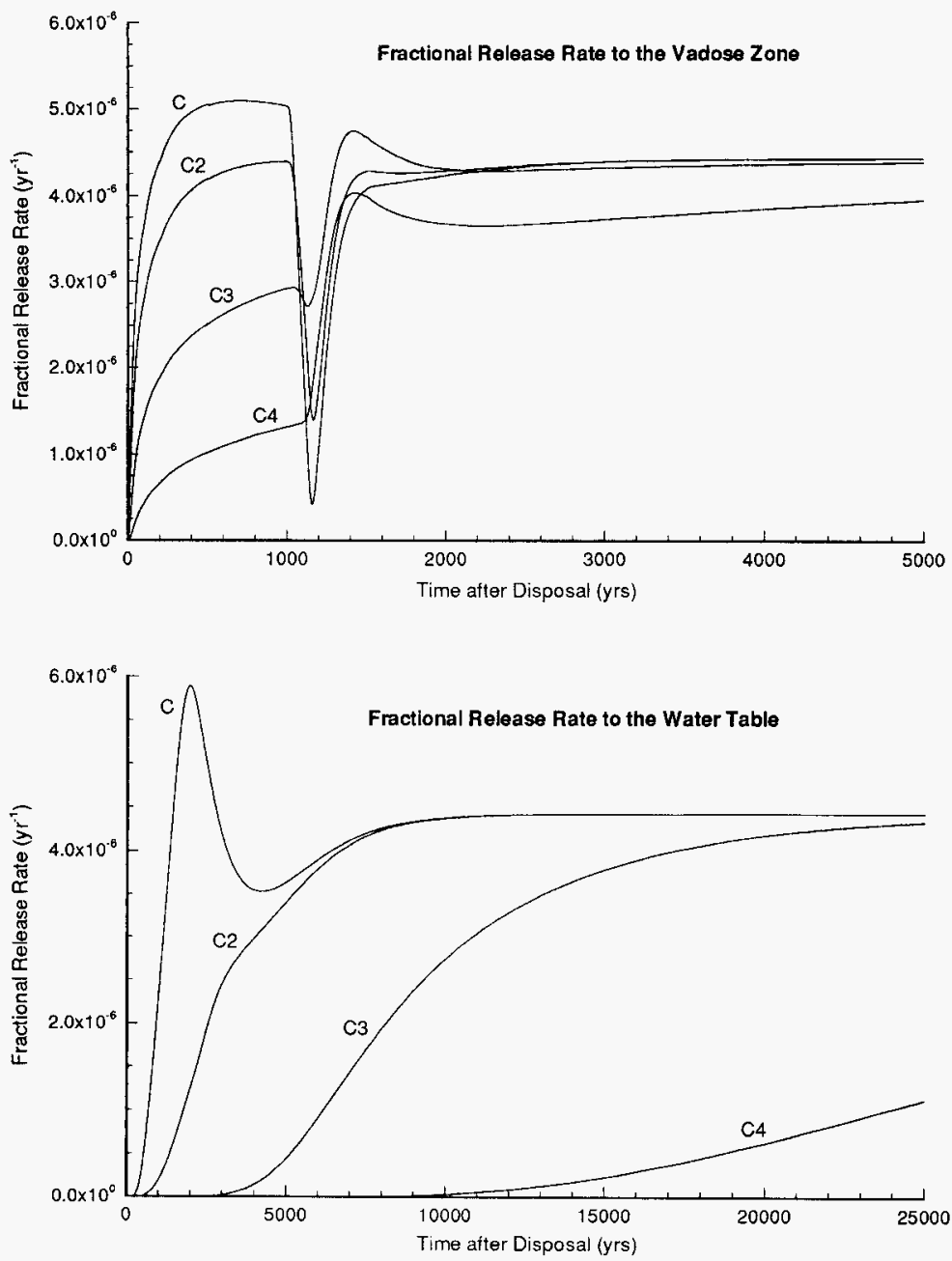
Figure 25. Simulated Fractional Release Rates for Sensitivity Case 18.
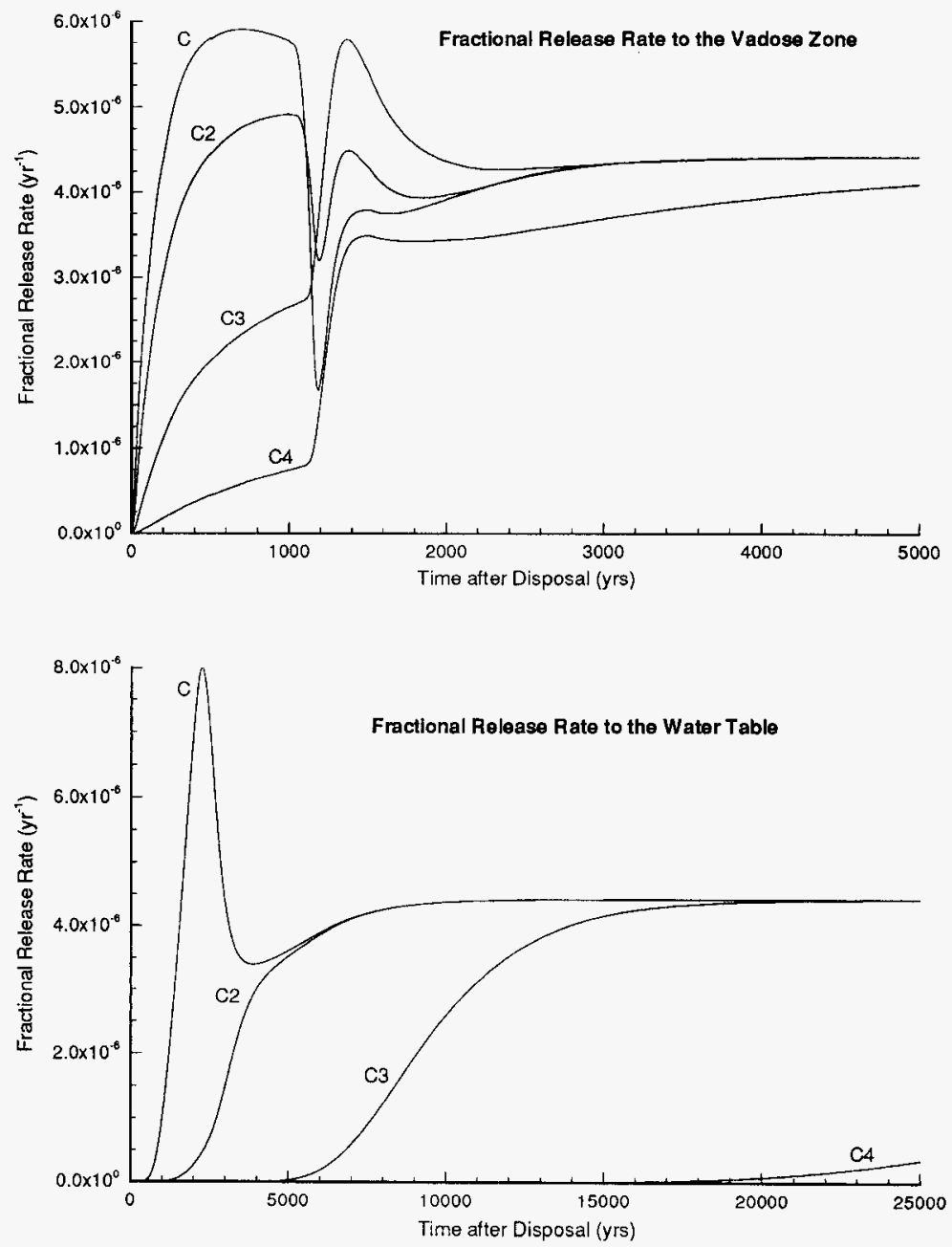
Figure 26. Simulated Fractional Release Rates for Sensitivity Case 19.
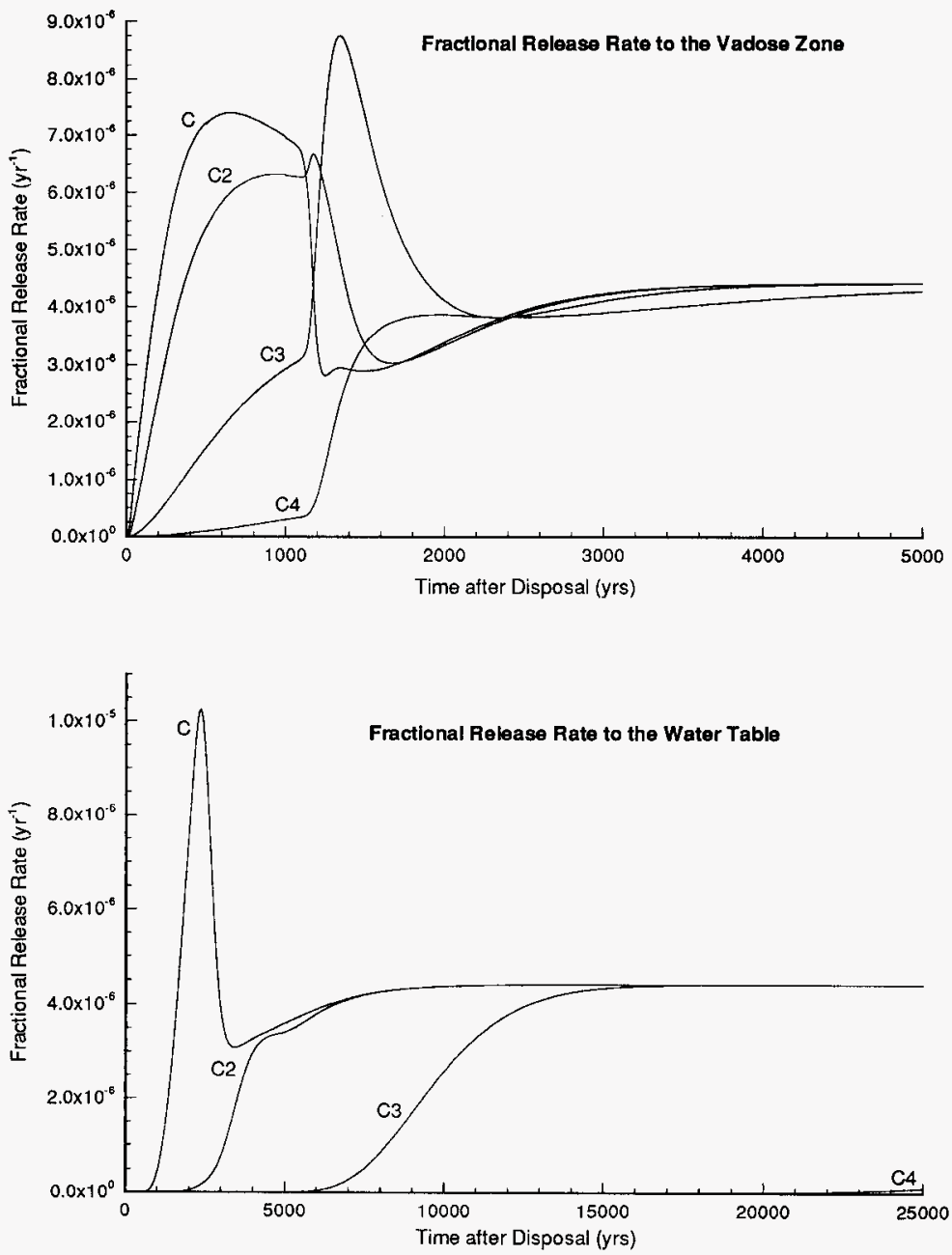
Figure 27a. Simulated Fractional Release Rates for Sensitivity Case 20.
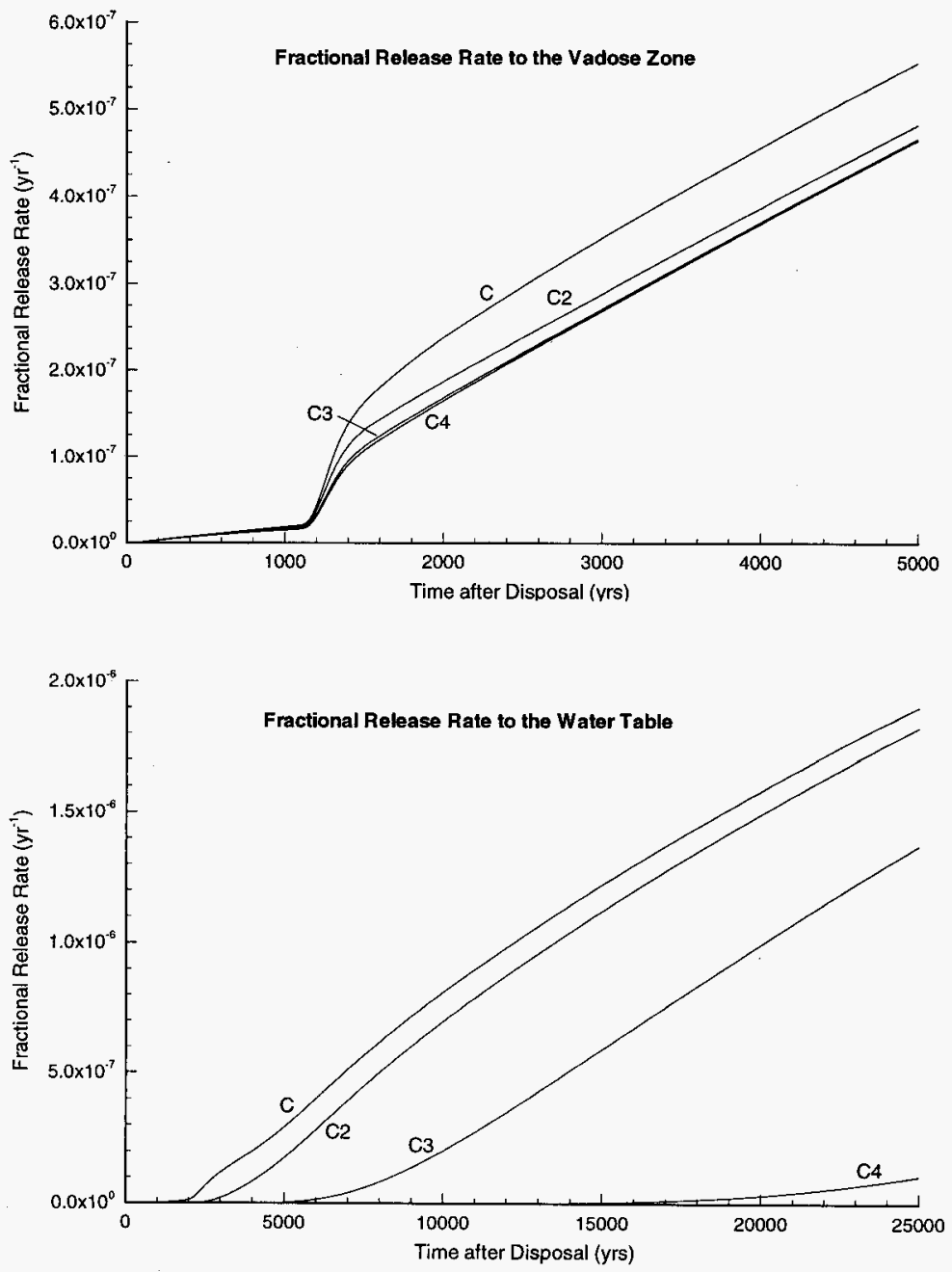
Figure 27b. Extended Simulated Fractional Release Rates for Sensitivity Case 20.
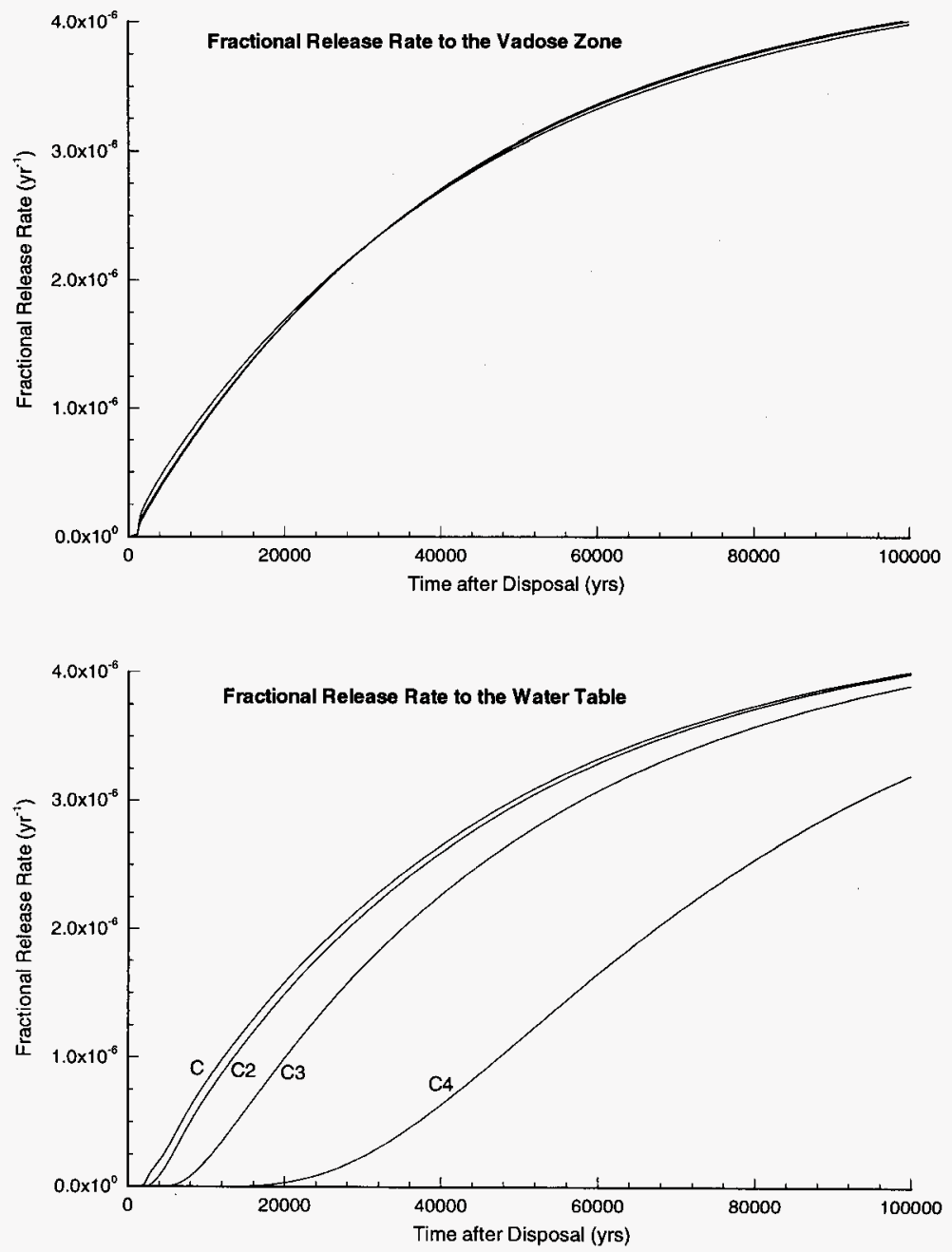
WHC-SD-WM-RPT-225, Rev. 0

Figure 28. Comparison of Analytic Source Terms.

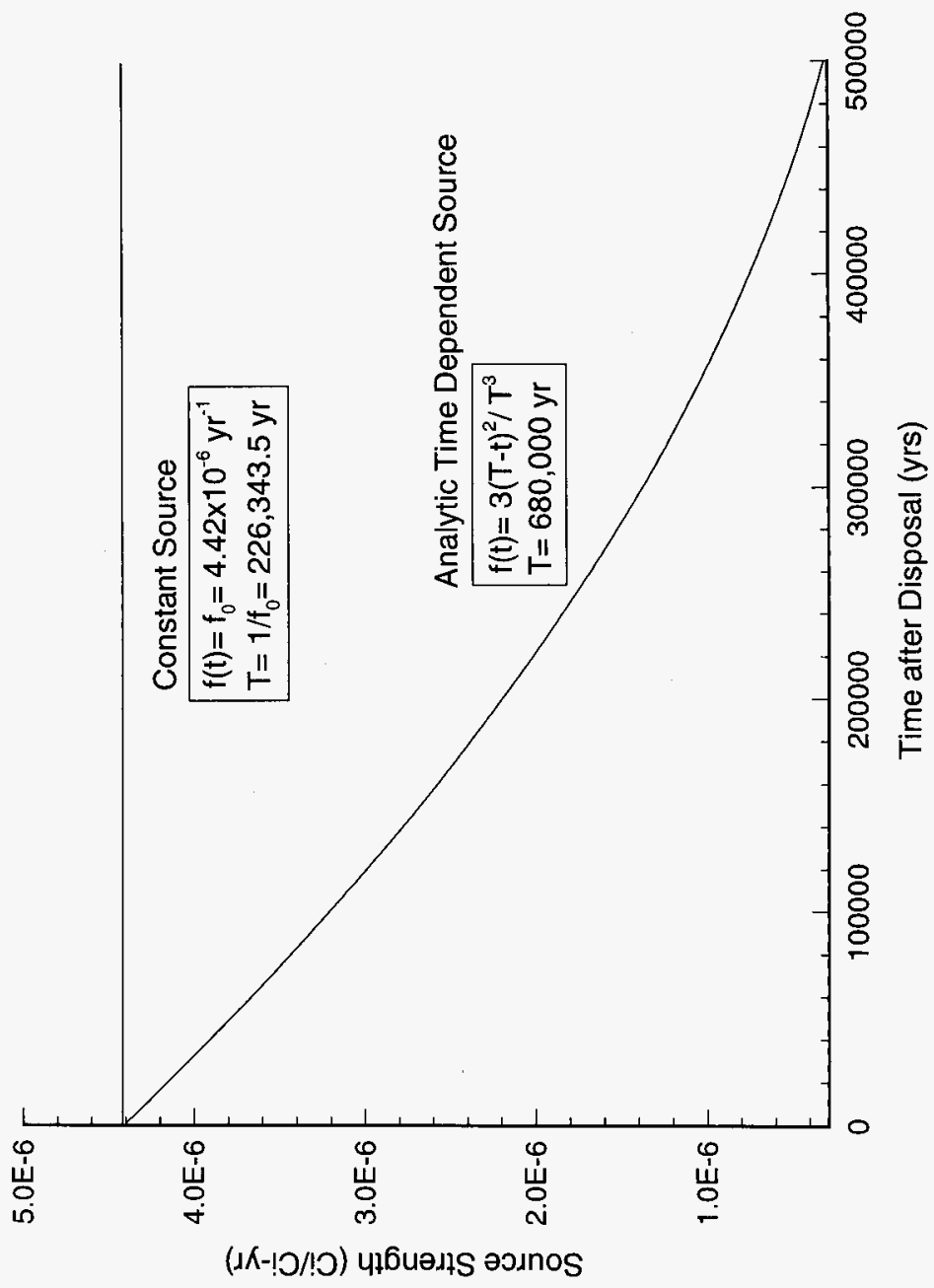


WHC-SD-WM-RPT-225, Rev. 0

Figure 29. Simulated Fractional Release Rates for Sensitivity Case 21.
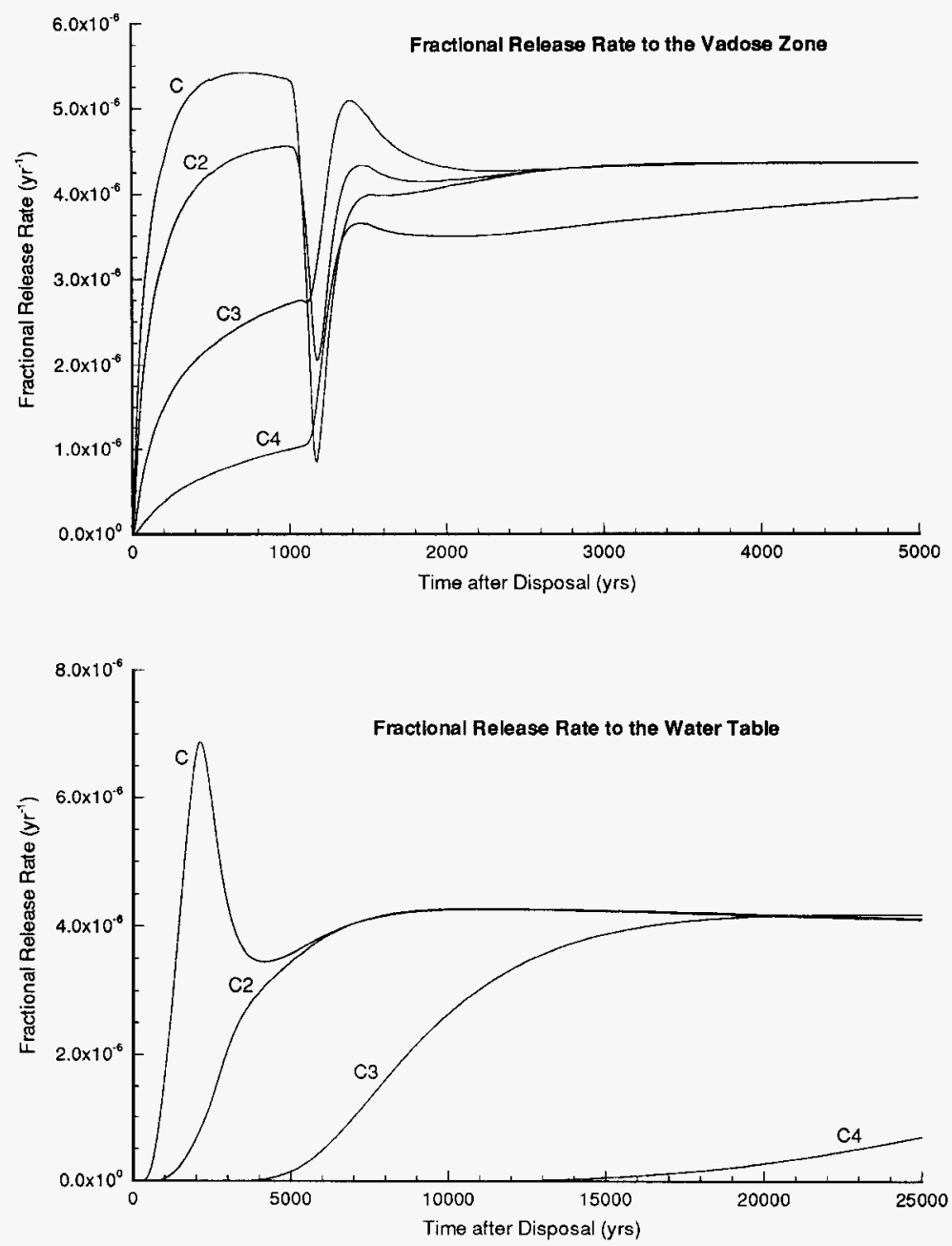
Figure 30. Source Term for Sensitivity Case 22.

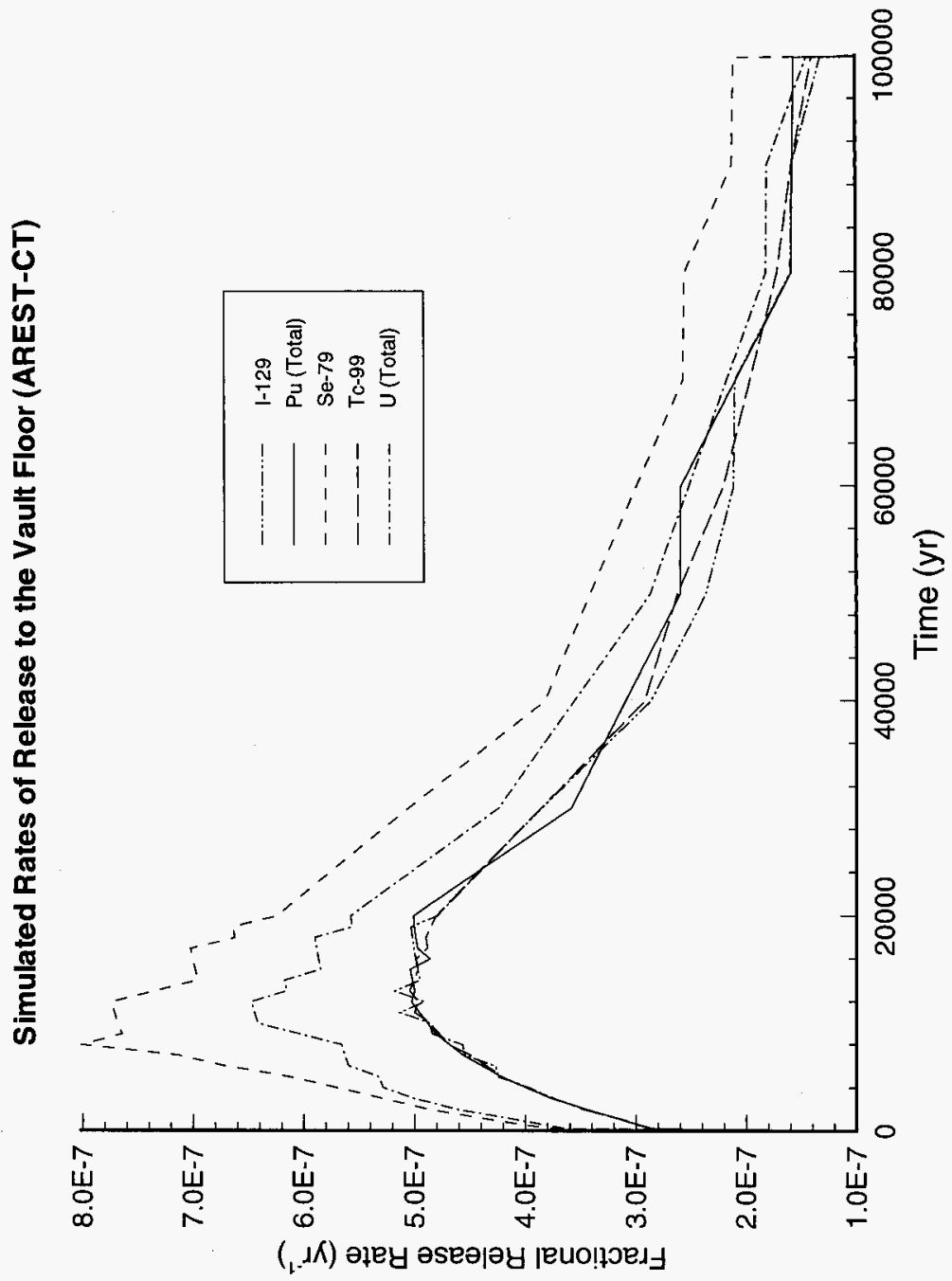


Figure 31. Simulated Fractional Release Rates for Sensitivity Case 22.
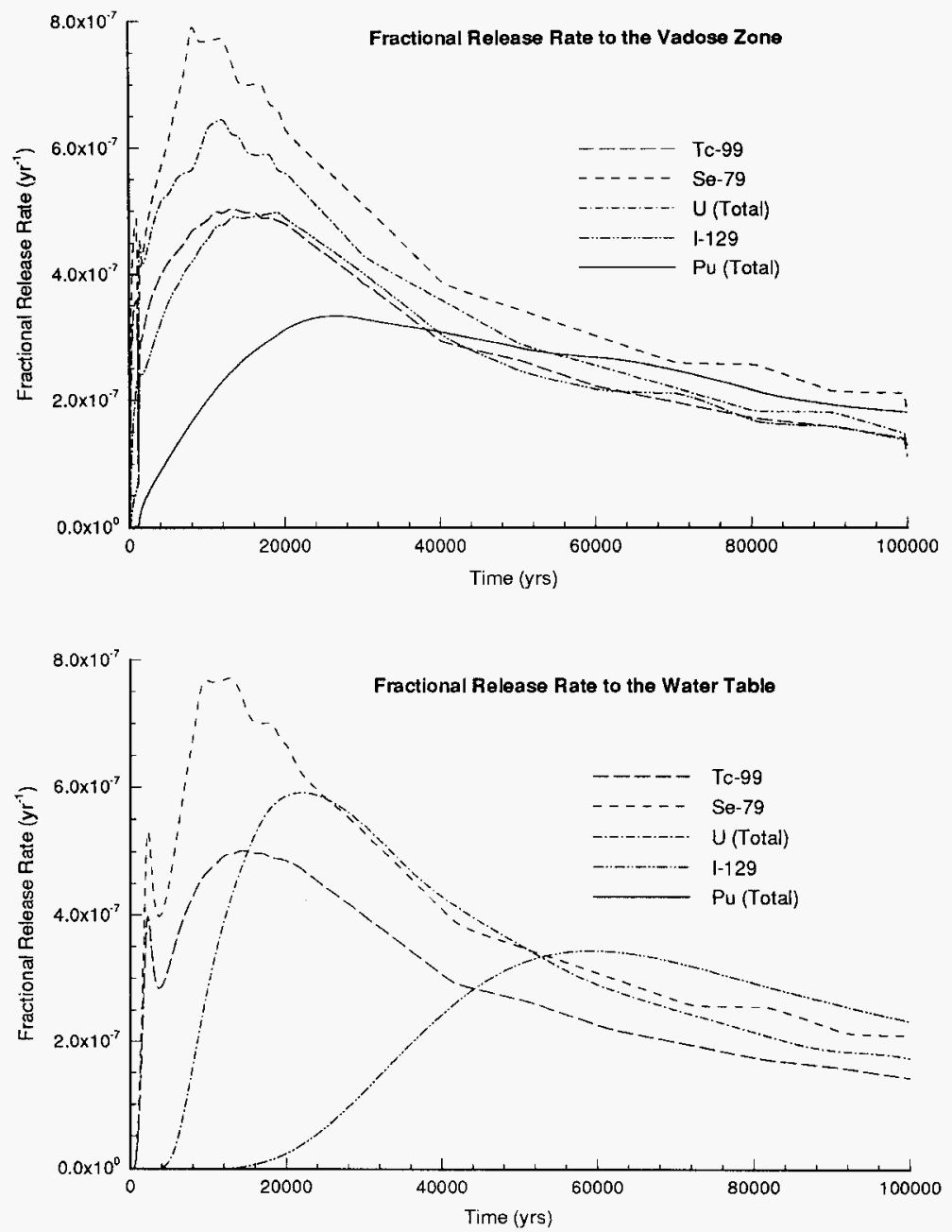


\section{APPENDIX A}

\section{NOMENCLATURE}

Symbol

Meaning

Units

$x$
$z$
$f$
$f_{0}$
$f_{f t}$
$f_{w t}$
$t$
$T$
$V_{0}$
$F_{0}$
$C$
$C N$

$\mathrm{F}_{0}$

$\mathrm{CN}$

$K_{d}$

$\mathrm{D}_{\mathrm{m}}$

$\alpha_{L}$

D

P

$\psi_{*}$

$\mathrm{z}$

9

U,

$\phi$

$\mathrm{K}$

$\mathrm{K}_{\mathrm{s}}$

$\alpha, n$

$\theta$

$\theta_{\mathrm{s}}$

$\theta_{r}^{\mathrm{s}}$

a

$\mathrm{q}^{\prime}$

A

Horizontal space coordinate

Vertical space coordinate

Fractional release rate from the waste form

Initial/constant value of $f$

Fractional release rate at vault floor

Fractional release rate at water table

Time after disposal

Duration of source

Volume of source region

Volumetric source term: $F_{0}=f_{0} / V_{0}$

Fractional concentration of 1 st species

Fractional concentration of Nth species $(N=2$ to 8$)$

Partition or distribution coefficient

Coefficient of molecular diffusion

Longitudinal dispersivity

Transverse dispersivity

Total diffusivity

Total head: $P=\psi+\left(z-z^{*}\right)$

Pressure head

Datum: Water Table is at $z^{*}=0$

Recharge rate

Horizontal and vertical Darcy velocities

Vertical pore velocity: $V^{\prime}=V / \phi$

Porosity

Hydraulic conductivity

Saturated hydraulic conductivity

Van Genuchten fitting parameters

Volumetric moisture content

Saturated volumetric moisture content

Residual volumetric moisture content

Saturation fraction: $S=\theta / \theta_{S}$

Barrier effectiveness, reciprocal of

large scale anisotropy

Total vertical fluid flux: $q^{\prime}=q^{A}$

Area of lateral cross-section: $A=1.05$

Cummulative moisture volume: $Q=q^{\prime} t=q A t$

$m$

$\mathrm{Ci} / \mathrm{Ci}-\mathrm{yr}$

$\mathrm{Ci} / \mathrm{C} i-\mathrm{yr}$

$\mathrm{Ci} / \mathrm{Ci}-\mathrm{yr}$

$\mathrm{Ci} / \mathrm{Ci}-\mathrm{yr}$

yr

$\mathrm{m}^{3}$

$\mathrm{Ci} / \mathrm{Ci}-\mathrm{yr}-\mathrm{m}^{3}$

$\mathrm{Ci} / \mathrm{Ci}-\mathrm{m}^{3}$

$\mathrm{Ci} / \mathrm{Ci}-\mathrm{m}^{3}$

$\mathrm{m}^{3} / \mathrm{kg}$

$\mathrm{m}^{2} / \mathrm{yr}$

m

$\mathrm{m}^{2} / \mathrm{mr}$

$m$

$\mathrm{m}$

$m$

$m / y r$

$m / y r$

$\mathrm{m} / \mathrm{yr}$

$\mathrm{m} / \mathrm{yr}$

$\mathrm{m} / \mathrm{yr}$

$\mathrm{m}^{3}, \overline{\mathrm{m}^{3}}$

$\mathrm{m}^{3} / \mathrm{m}^{3}$

$\mathrm{m}^{3} / \mathrm{m}^{3}$

-

$\mathrm{m}^{3} / \mathrm{yr}$

$\mathrm{m}^{3}$ 
WHC-SD-WM-RPT-225, Rev. 0

APPENDIX B

\section{REFERENCED CORRESPONDENCE}

Piepho, M. G., 1996 Page B-2

McGrai1, B. P., 1996 Page B-13 


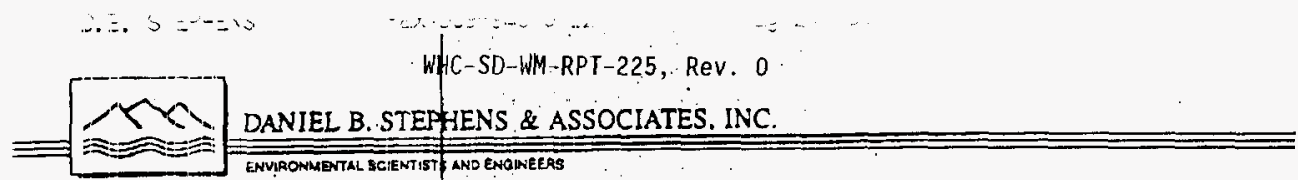

DBSA-PNWB-96-42

May 24, 1996

LOW-LEVEL-VITRIF|CATION-WASTE PERFORMANCE ASSESSMENT

FLOW AND TRANSPORT MODELING

By.
Mel Plepho

\subsection{INTRODUCTION}

Danol B. Stephens A Associates, Inc. Richland, WA 99352

This document describes the work performed by Daniel 8 . Stephens \& Associates, Inc. for Golder Federal Services under contract G-96-301. Golder Federal Services was on contract to Westinghouse Hanford Co. Lnder a Hanford Basic Ordering Agreement. The work consisted of modeling the flow of water and transport of contaminants in and around the proposed Low-Level-Vitrification-Waste Disposal Facility at Hanford in the vadose zone. The work involved flow and transporf modeling in only the vadose zone at Hanford, using the WHC selected PORFLOW code (Runchial et al, 1992):

The purposes of this document are 1) to describe the differences between the base-case run performed and the input parameter values defined in the Westinghouse Hanford Co. (WHC) base-analysis document (Mann et al. 1995), 2) to briefly describe the computer runs and results of the base-case analysis simulation and sensitivity computer runs. Many of the parameter. values used in the simulations are exactly as prescribed on the base-analysis document, but some parameter values, such as the mesh, were left up to the user and others had to be modified to be consisfent with the computer code's capabilities. The base-analysis case is defined for Concept One of the disposal facility design. The Concept-Two design simulation is considered as a s\&nsitivity case to the base-analysis case of Concept One. However, since the Concept Ore computer runs took a very long time to run (over $100 \mathrm{CPU}$ hours on an IBM $580^{\circ}$ work statipn), most of the sensitivity runs were variations of the base Concept Two simulation. Thre simulations were performed for Concept One and ten simulations were performed for Concept Two.

2.0 PARAMETER VALUE DIFFERENCES

The simulations performed as part of this project used the input data presented in Mann et al. (1995) with following exception descrlbed bolow.

2.9 Diffusion/Dispersion - The diffusion coefficient was specified in Mann et al. (1995) to be $1.27 \mathrm{E}-7 \mathrm{~cm}^{2} / \mathrm{s}$ in conjunction with the Kemper diffusion model (Kemper 1966). The moisture-dependent factor was specified to be exp(10*mois), which is based on the Kemper (1966) diffusion model. However, with the PORFLOW code (Runchal et al, 1992), if the Kemper diffusion model is used, then dispersion capability is not available. Since dispersion coefficients were specified in the base-analysis document in Table 14-1, I decided to use the Scheidegger (1961) dispersion/diffusion model that was also available in PORFLOW. With the Scheidegger model, the midisture content is multiplied by the diffusion coefficient and tortuosity factor to obtain the effective diffusion term. The dispersion term, which is velocity

SOL MND OROUNO-WATEA INVESTIOATIONS - REMEDUL ACTION - LTTIGATION SUPPORT - VADOSE ZONE HYOAOLOGY

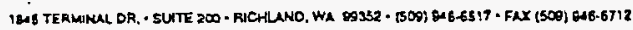


D. B. STEPHESS

$=a x: x y-y-0-. .2$

WHC-S[D-WM-F.PT-225, Rev. O

DANIEL B. STEPHENS \& ASSOCLATES, INC.

dependent is added onto the effective diffusion term. To find the effective diffusion term, mois*tau*D, the Scheidegger difusion term, was set equal to $1.27 E-7^{*} \exp \left(10^{*}\right.$ mois), the Kemper diffusion term, when the moisture content was 0.05 which is lowest value that the Kemper model will accept. This value also represents a fairly low value of moisture content which is representative of the doy regions at Hanford, and the Kemper diffusion term is minimized at this value. In othe words.

$$
0.05^{\circ}\left(\operatorname{tas}^{*} p\right)=1.27 E-7 * \exp (0.5)
$$

which implies that tau* $D$ is approximately equal to $5.0 \mathrm{E}-6 \mathrm{~cm}^{2} / \mathrm{s}$ rounding up. Since the solute diffusion coefficient in waler is around $2.5 \mathrm{E}-5 \mathrm{~cm}^{2} / \mathrm{s}$, then the tortuosity factor (tau) value is 0.2 in the soils. It's of ifterest to note that if one does not include the moisture content factor $(0.05)$ of the left-hand side of the above equation, the tortuosity factor value reduces to 0.01 , which is twenty times smaller than the derived base-case value. Hence, the smalier tortuosity value $(0.01)$ will define a sensitivity case where the effective diffusion term value is wenty times smaller the base-analysis case tortuosity value (0.2).

The longitudinal dispersion coefficient was specified in the base-analysis document (Mann et al., 1995) to be 0.1 of the travel path from the disposal facility to the groundwater. Since the disposal facility isn't a point soulce, half of the height of the disposal facility was added to the distance below the disposal facility to the groundwater which was $80 \mathrm{~m}$. Hence. The longitudinal dispersion coefficient was estimated to be $8.5 \mathrm{~m}$ and the transverse dispersion coefficient was estimated to be 0.1 of the $8.5 \mathrm{~m}$ for a value of $0.85 \mathrm{~m}$. Since these relatively large values of dispersion would overstate the release from the disposal facility, they were not used in the disposal facility iself, but were used for the soils below the facility. Hence. the disposal facility would release contaminants by advection and diffusion only.

\subsection{Grid Size and Mesh}

The two-dimensional mesh, with includes the vadose zone above $166 \times$ values and $133 Z$ values (for a total of 21780 cells) the 200 East Area on the Hanfdrd Site. The top dry surface barrier is not included in the model as the design recharge rate, $0.05 \mathrm{~cm} / \mathrm{yr}$, through the surface barrier is used for the first 1000 years, and a higher rechalge rate, $0.3 \mathrm{~cm} / \mathrm{yr}$, is used after 1,000 years as the top boundary condition of the mode domain. The vertical height in the model domain is 98.75 $\mathrm{m}$. This gives the location of the bottom of the vault pad at 200.25 meters above mean sea level, not 200 meters as stated in Table $8-1$ in the base-analysis document.

The horizontal distance from th center of the disposal facjity to edge of the model domain is $124 \mathrm{~m}$ with the half-width of the disposal facility being $105 \mathrm{~m}$ which inctudes the gravet vertical barrier on the outside eqge of the disposal facility. Hence, there is $19 \mathrm{~m}$ of backfill soil from the outer edge of the disposal facility to the right boundary of the model domain. The right and left boundaries ap no-flow boundaries. The mesh for Concept One design is shown in Figure 1.. It includes $\$ 5$ canisters with nine canisters in each vault bay which is identified by a $1-\mathrm{m}$ thick concre e intemal wall. The vertical grid size is very small, $15 \mathrm{~cm}$, 


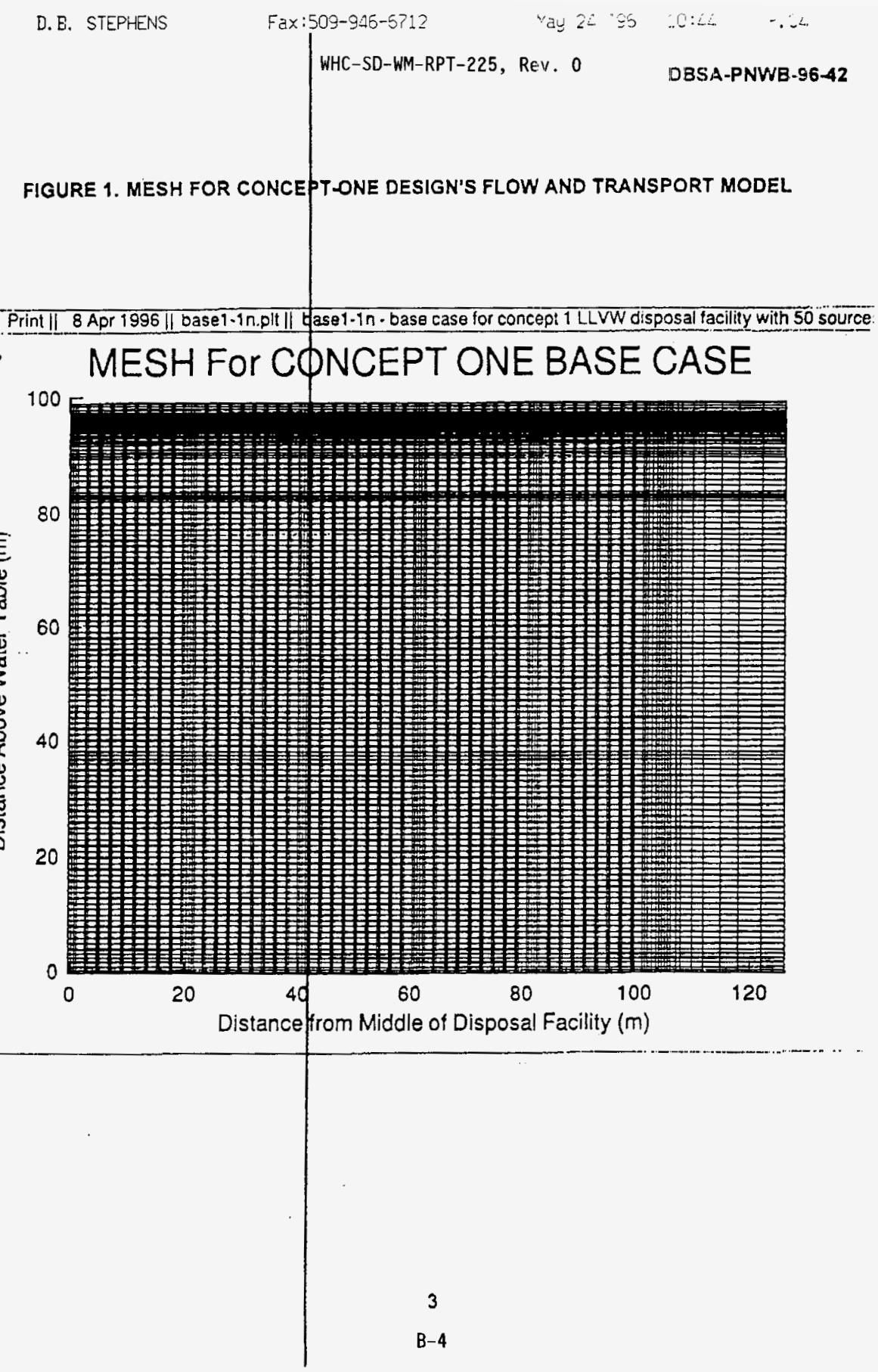


D. . STEPUEVS

$=a x: 50 \Omega-2<5-57: .2$

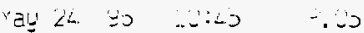

WH-SD-WM-RPT-225, Rev. 0

DANIEL B. STEPHENS \& ASSOCIATES, INC.

near the top of the model domain so that the water nun-off from the sloped gravel barrier could be modeled more accuratily (i.e., the smaller vertical grid size resulls in smaller horizontal grid space for the stat-steps representing the slope). The slope is defined by a 4$\mathrm{m}$ height over a $105-\mathrm{m}$ width, which is equivalent to an angle of 2.18 degrees, not 2 degrees as stated in Table $8-2$ of the base-analysis document.

\subsection{Impermeable Canisters and Source Term}

The canisters or containers of the vitrified waste are stated to have no effects on hydraulics or on chemical retardation in tha base-analysis document (p. 21 of Mann et al, 1995).

However, since some water is ekpected to flow some of the time in the disposal facility, it is impossible for the canisters not fo have some effect even they are impermeabie. Hence, to minimize their effects on the hydrology, an impermeable saturated conductivity value of 1.0E-30 $\mathrm{m} / \mathrm{yr}$ was chosen.

Also, the diffusion coefficient was chosen to be very small with a value of $7.89 E-30 \mathrm{~m}^{2} / \mathrm{yr}$ so that the canisters would not participate in the transport of contaminants. In fact, a very low value of porosity, 0.0001 , was chosen for the canisters so that if any contaminant diffused into the canister, the concentration in the canisters small porosity would increase very rapidly, resulting in a concentration gradient going out of the canisters. Also, with the canisters' porosity so small, unsaturated parameters for a tight formation could be used which will tend to keep the canisters saturated h the model with a very small water content. Since the canisters are not participating in the flow and transport model, the contaminant source term was placed in the soil between the canisters. In reality, some of the contaminants emanating from the glass canisters would be above and below the canisters. However, for modeling purposes, it is easier to place all of the contaminant source on the sides of the canisters, and this should be conservative as the advection should be greater along the sides of the canister than on the top or bottom.

The source rate from the glass fanisters was specified to be no greater than $4.4 \mathrm{E}-6$ fraction/yr (i.e. 4.4 parts per mill on per year). Furthermore. Tc-99 is to be released at rate five times smaller than $4.4 \mathrm{ppm} / \mathrm{r}$. The release rate is decreased over time as specified in the base-analysis document (Mann et al, 1995) by Table 11-1 which should read

$$
3^{*}(T \text {-time }(\text { years }))^{2} \mid \pi^{3} \text {, where } T=680,000 \text { years, }
$$

as $3 / 680,000$ is about $4.4 E-6 / y r$. It of interest to note, for mass-balance purposes, that the time-integration of the source rate above for the first 100,000 years (with $T=680,000$ years) is equal to 0.379 and is equal to 1,0 over the full 680,000 years $(T)$.

\subsection{Water-Conditioning Laver}

Crushed glass is placed above he horizontal roof of the disposal facility as a waterconditioning layer for the glass canisters so that the water will not corrode the glass very 
much. The water-conditioning lafyer would only be useful if water-made it's way through the sloped gravel barrier above the conditioning layer. However, the hydraulic conditions for the water-conditioning layer were ndt specified in the base-analysis document. Hence, the analyst assumed gravel properties, which were given in the base-analysis document, for the crushed glass.

All of the other parameters use in the base-analysis model for Concept One are defined clearly in the base-analysis model (Mann et al, 1995) and are not duplicated here.

\subsection{SIMULATIONS FOR CONDEPT ONE}

The base-case simulation for th concept-one disposal facility design is already defined in Section 1.0 along with the base case document (Mann et al, 1995) which is devoted to defining the base-analysis case and the sensitivity cases. All of the files for these cases are located on the SECC disk directpry /home/mxp882/ipa2 with the ".rel files containing the release rates to the aquifer, the f.tec fles containing the spatial values of the primary variables are various points in time, the ".out files containing all of the output information and the "inp being the input files. The "flx files are the flux files which includes the contaminant advective and diffusive flux from the bottom of the disposal facility to the vadose below it (flux \# 12).

\subsection{Base Case - base 1-10}

The base-case simulation has the name base1-1d and the resulting files are stored on the SECC (Science and Engineerind Computing Cenler) disk space in directory /mxp882/ipa2 with base 1-1d.rel being the fractonal release-rate file, base1-1d.out being the output file, base1-1d.arc being the archive file and base1-1d.tec being the TECPLOT Ascii file.

The main feature of the base-case simulation is that it shows that the sloped gravel barrier above the disposal facility fails shortly after 1000 years when the recharge increases from $0.05 \mathrm{~cm} / \mathrm{yr}$ to $0.3 \mathrm{~cm} / \mathrm{yr}$. The sloped gravel barrier fails because the horizontal distance is too long $(105 \mathrm{~m})$ for the small slope of only 2.18 degrees. In future designs, the slope should be increased to about 4 degrees or more, or the horizontal span should be decreased.

Mass balance has been a problom for the concept-one base-case simulation. The massbalance error occurs in the lowe Hanford formation (gravelly sand) and upper Ringold formation, and not in the dispos ol facility. This is surprising since the disposal facility has many details including canisters soll between canisters, vertical and horizontal concrete. degrading concrete, etc. With all of the contrasts in the disposal facility, one would expect any mass-balance problem to occur there, but the mass-balance problem for the base case occurs in the Hanford Formation. The reason for this is partly due to the small porosity values, 0.1312 and 0.1342 , that was assigned to the lower Hanford formation the Ringold formation, respectively. The un alurated parameters for these two formations also promoted a slow drainage so that it took a long time to reach steady-state conditions. Since the computer times were so long (nfore than 100 hours on an IBM 580 workstation), the flow simulation was stopped when steady-state velocities were reached. However, even after 
D.E. STEPHENS

DANIEL B. STEPHENS \& ASSOCIATES, INC.

4000 years after disposal the v $\$$ locities were not quite at their steady-state values which caused a mass-balance error in the ransport simulations at much later times. The massbalance error is shown in Table 1.

TABLE 1. Mass-Balanee Error Over Time for Moblle Species for Case base1-1d

\begin{tabular}{|c|c|}
\hline TIME (yrs) & MASS-BALANCE ERROR \\
\hline 21,500 & $0.5 \%$ \\
\hline 37.500 & $2.1 \%$ \\
\hline 53,500 & $3.5 \%$ \\
\hline 69,500 & $4.8 \%$ \\
\hline 85,000 & $5.9 \%$ \\
\hline 100,000 & $6.7 \%$ \\
\hline
\end{tabular}

The fractional release rate to the aquifer is monotonic increasing and reaches a maximum value around 3.5E-6/yr at 100, po years. However, due to the gradual growth of massbalance error, this rate is probaply too high, but should not be more than six percent too high.

\subsection{Case base1-in}

This case is exactly the same as the base case (base1-1d) except that the diffusion coeficient $\left(2.5 \mathrm{E}-7 \mathrm{~cm}^{2} / \mathrm{s}\right)$ is twe hty times smaller than the base case's diffusion coefficient of $5.0 \mathrm{E}-6 \mathrm{~cm}^{2} / \mathrm{s}$ for all porous meda except the concrete formations which have a diffusion coefficient $\left(5.0 \mathrm{E}-8 \mathrm{~cm}^{2} / \mathrm{s}\right)$ that is 100 times smaller than the base-case diffusion coefficient for concrete. The diffusion coefficiont does not have much importance below the disposal facility since dispersion is expected to pominate there. However, since there is no dispersion modcicd in the diopoool fooility, the diffucion coofficient is much more important in affecting the release of contaminants into the vadose zone. If concrete has a lower diffusion coefficient than the soils, then coedit should be taken for this in future performance assessments. It would also be pf interest to know what the diffusion coefficient for degraded concrete since concrete is assumed to be degraded after 500 years from disposal. Also, the importance of the concrete diffusion coefficient decreases if the sloped barrier fails to prevent infiltrating water from entering the vaults. It doesn't take much infiltrating water to dominate the diffusive release process.

The fractional release rate to the aquifer is monotonic increasing and reaches a value of $2.4 \mathrm{E}-6 / \mathrm{yr}$ at 100,000 years, whikh is lower than the base case (case base $1-1 \mathrm{~d}$ ) release rate due to the smaller diffusion coefficients used in case base1-1n. 
D. . STEPHENS

DANIEL B. STEPHENS \& ASSOCIATES, INC:

\subsection{Case base $1.2 d$}

This sensitivity case is same as the base case (base1-1d) except that the concrete floor degrades at 2000 years instead of 500 years. This simulation needed the flow simulation carried out to 5500 years, instead of 4000 years as in the base case. because of the $1500-y \mathrm{r}$ delay in the concrele floor failure.

The fractional release rate to the aquifer is monotonic increasing and reaches a value of $3.6 \mathrm{E}-6 / \mathrm{yr}$ at 100,000 years. However, the mass balance error at 100,000 years is failly high with an error of $8 \%$ which is higher than the base case mass balance error. Basically, the time of failure of the concrete floor, as long as it's between 500 and 2000 years does not have much effect on the release rate to the aquifer.

\subsection{Case base1-5d}

This sensitivity case is the same as the base case except that the recharge is initially 10 $\mathrm{cm} / \mathrm{yr}$ and stays at that value folever, and the concrete is assumed to be initially degraded instead of at 500 years after disposal as in the base case. This simulation takes over 400 hours of CPU time on an IBM 580 workstation; hence, it was never completed. However, it was completed for the Concept Two design of disposal facility and is presented later.

\subsection{SIMULATIONS FOR CONDEPT TWO}

The base-case simulation for the concept-two disposal facility design is basically defined in Section 1.0 along with the base case document (Mann et al. 1995) which is devoted to defining the base-analysis case and the sensitivity cases. The concept-two base case can be viewed as a base case or as a sensitivity case to the concept-one base case. Since several sensitivity cases were run for the concept-two design, there will be a base case for it in the following discussion. The files for of the following runs are contained on the SECC disk directory /home/mxp882/ipdpe.

\subsection{Base case - base2-10}

The first number in the file name, base2-1d, denotes the concept-two design. This case is exactly the same as the base case for concept-one design, base1-1d, except that the horizontal mesh is much smalle in order to simulate only one vault. Only one vault, actually half of one, is simulated since qch vault under concept-two design has a sperate sloped gravel barrier above it. The meh contains $38 \mathrm{X}$ nodes and $133 \mathrm{Z}$ nodes for a total of 4884 cells. Since only a half vault is hodeled, only four canisters are contained in the model.

This simulation had very little mass-balance error (less than $2 \%$ ) for the entire 100,000 years of simulation. The peak release rate is $4: 25 \mathrm{E}-6 / \mathrm{yr}$ around 15,000 years after disposal. 


\subsection{Sensitivity case-base $2-1 n$}

This case is exactly the same as the base case except that the diffusion coefficients are smaller as defined in case bask1-1n. In other words, base $-1 n$ is exactly the same as case base $1-1 \mathrm{n}$ except for the differeht mesh (different concept), and is exactly the same as case base 2-1d except that the diffus on coefficients are smaller.

The simulation had very little mess-balance orror (less than $2 \%$ ). The peak release rate to the aquifer is $3.3 E-6 / y r$ around 83,000 years. Hence, this shows that the diffusion rate from the vaults is important.

\subsection{Sensitivity case - base2-20}

Case base2-2d is exactly the skme as the base case except that the source term rate is held st a constant rate of $4.4 \mathrm{E}-6 / \mathrm{yr}$ for the entire 100,000 years, with the source rate for Tc-99 being five times smaller. This case was to test the mass-balance in regards to an asymptote release rate to the aquifer which should be the same as the source term rate from the disposal facility and was calculated to be $4.389 \mathrm{E}-6 / \mathrm{yr}$. This compares very well to $4.4 \mathrm{E}-6 / \mathrm{yr}$ with some the mass perhaps lequing the modeling domain on top and the rest being an error which is very small:

\subsection{Sensitivity case - base $2-2 n$}

This case is exactly the same as case base2-2d, except that the diffusion coefficients are smaller are described earlier. on other words, this case is the same as case base2-in except. that the source term rate is constant. This runs shows how the diffusion coefficient in the disposal facility effects the reledse rate to the aquifer when the source term rate is constant. At 100,000 years after disposa, the release rate to the aquifer has reached $4.1 \mathrm{E}-6 / \mathrm{yr}$, which is still not the steady-state value.

\subsection{Sensitivity case - bas $2-2 \mathrm{dd}$}

This case is exactly the same as case base2-1d, except that the concrete floor doesn't fail until 2000 years after disposal hstead of at 500 years. The first cell above the concrefe floor is about $75 \%$ saturated at 1000 and 2000 years after disposal. Hence, an intact concrete floor acts as a porous bath tub which keeps some of the water in the water in the vault from leaking out, but cannot keep al of the water from leaking out: The maximum fractional release rate to the aquifer is 4,6E-6/yr at 15,600 years. Hence, the concrefe floor doesn't appear to affect the release rate to the groundwater very much, but merely delays the peak release by about 500 years and increases the peak rate slightly from $4.25 E-6 / y r$ to $4.3 E-6 / y r$.

\subsection{Sensitivity case-base $2-30$}

This case is exactly the same of the base case except that the sloped gravel barrier above the vault is initially degraded. One half of the gravel is replaced with backfill soil about two/thirds of the way down from its apex. Hence, water infiltrates through this soil and removes waste out of the vault into the vadose zone. 


\subsection{Sensitivity case - base $2-40$.}

This case is exactly the same os the baise case except that no side capillary barrier next to the vault side is present. Inste do backfill soll takes the place of the gravel that was present in the base case. The maximu n release rate to the aquifer is $4.31 \mathrm{E}-6 / \mathrm{yr}$ around 10.000 years after disposal.

\subsection{Sensitivity case-base2-50}

This case is the same as the bise case except that the recharge has been increased to 10 $\mathrm{cm} / \mathrm{yr}$ for the entire 100,000 years of simulation. The maximum release rate to the aquifer is $4.41 E-6$ at 9,000 years after disposal. Hence, the higher release causes the peak release to occur about 6,000 years eartier than the lower recharge, but the peak rate value is about the same. This mainly due to the flet that the gravel-wedge barrier still works for the $10 \mathrm{~cm} / \mathrm{yr}$ recharge, and, hence, the release from the disposal facility is still controlled by diffusion.

\subsection{Sensitivity case - base $2-60$}

This case is the same as the base case except that the disperslon coefficients are one half of the base case's dispersion coefficients. In other words, the longitudinal coefficient is $42.5 \mathrm{~m}$ and the transverse coefficient is $0.425 \mathrm{~m}$. The maximum release rate to the aquifer is 4.24 around 15,000 years after disposal, which is very similar to the Concept Two base case.

\subsection{Sensitivity case - basez-7y}

This case is the same as the base case except that the dispersion coefficients are twice as big the base case's dispersion coefficients. In other words, the longitudinal coefficient is 170 $\mathrm{m}$ and the transverse coefficien is $4.7 \mathrm{~m}$. The maximum release rate to the aquifer is $4.26 \mathrm{E}$ 6 around 14,000 years after disposal, which is very similar to the Concept Two base case. 
ग.3. STDES

-ax:529-2 $55-5 r \ldots$

WHC-SD-WM-RPT-225, Rev. D.

DANIEL B. STEPHENS \& ASSOCIATES. INC.

DBSA-PNWE-96-42

\subsection{SUMMARY}

The fractional-release-rate results of all of the cases are summarized in TABLE 2.

TABLE 2. Fractional Release Rates to Aquifer for All Cases

\begin{tabular}{|c|c|c|c|c|}
\hline Case Name & Brief De & oscription. & $\begin{array}{l}\text { Peak Release } \\
(1 / \mathrm{yr})\end{array}$ & $\begin{array}{l}\text { Time of Peak } \\
\text { Release (yrs) }\end{array}$ \\
\hline \multicolumn{5}{|c|}{ CONCEPT ONE CASES } \\
\hline base $1-1 d$ & Base & Case & $<3.5 \mathrm{E}-6$ & 100,000 \\
\hline base1-1n & Lower & biffusion & $<2.4 E-6$ & 100,000 \\
\hline base1-2d & $\begin{array}{l}\text { Concrete Floo } \\
\text { yrs instea }\end{array}$ & $\begin{array}{l}\text { fr Fails at } 2000 \\
\text { of } 500 \text { yrs. }\end{array}$ & $<3.6 \mathrm{E}-6$ & 100,000 \\
\hline \multicolumn{5}{|c|}{ CQNCEPT TWO CASES } \\
\hline base2-1d & Concept TY & W Base Case & $4.25 E-6$ & 15,000 \\
\hline base2-1n & Low $D$ & iffusion & $3.30 \mathrm{E}-6$ & 83,000 \\
\hline base2-2d & Constant \$ & \$ource Rate & $4.39 E-6$ & $\begin{array}{l}25,000= \\
100,000\end{array}$ \\
\hline base $2-2 n$ & $\begin{array}{l}\text { Conistant } \\
\text { Low }\end{array}$ & $\begin{array}{l}\text { Source Rate. } \\
\text { fiffusion }\end{array}$ & $4.08 \mathrm{E}-6$ & 100,000 \\
\hline bas2-2dc & $\begin{array}{c}\text { Concrete Flod } \\
\text { yrs instead }\end{array}$ & $\begin{array}{l}\text { Fails at } 2000 \\
\text { of } 500 \text { yrs }\end{array}$ & $4.40 \mathrm{E}-6$ & 15,500 \\
\hline base2-3d & Sloped Ban & fer Degraded & 4.19E-6 & 14,000 \\
\hline base2-4d & No Side & Pry Barrier & $4.31 \mathrm{E}-6$ & 10,000 \\
\hline base2-5d & High Rechay & ge $(10 \mathrm{~cm} / \mathrm{yr})$ & $4.41 \mathrm{E}-6$ & 9,000 \\
\hline base2-6d & One Half Bं & Se Dispersion & $4.24 \mathrm{E}-6$ & 15,000 \\
\hline base2-7d & Twice Bas & Dispersion & $4.26 \mathrm{E}-6$ & 14,000 \\
\hline
\end{tabular}


D. B. STEPHENS

vas $26.95 \quad: 0: 50 \quad=. .2$

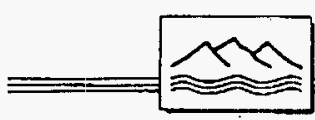

WHC-SD-WM-RPT-225, Rev. 0

DBSA-PNWB-96-42

6.0 REFERENCES

Keeper, W.D., and J.C. Van Sthaik. 1966. "Diffusion of Salts in Clay-Water Systems", Soil Sci. Am. Proc. 30:534-540.

Mann, F.M, C.R. Eiholzer, R. Khaleel, N.W. Kline, A.H. Lu; B.P. McGrall, P.D. Pittman, and F. Schmittroth. 1995. Definition of the Base Analysis Case of the Interim Performance Assessment, WHC-SD-WM-RP F-200, Rev. 0, Westinghouse Hanford Co., Richland, Washington.

Runchal, A.K., and B. Sugar, f992. PORFLOW: A Mathematical Model for Fluid, Flow, Heat and Mass Transport in Multifluid. Multiphase Fractured or Porous Media, Users Manual, Version 2.4, ACRi/016/Rev G. Analytic and Computational Research Inc., Bel Air, California.

Scheidegger A.E. 1961. "General Theory of Dispersion in Porous Media", J. Geophysical Research 66:3273-3278. 
WHC-SD-WM-RPT-225, Rev. 0

'rom: Bernard P McGrail at -PNL19 5/8/96 3:02PM (2987 bytes: 1 in)

iall W Kline at $\sim B C S 4$

rederick M Mann at -MailLink, Yueting Chen at -SMTPLink

ct: AREST-CT Simulation Results

- Message Contents

Niall,

The attached tar file contains our first simulation results using AREST-CT for the Interim Performance Assessment. Results for 6 radioactive elements are included: $\mathrm{TC}, \mathrm{I}, \mathrm{U}, \mathrm{Se}, \mathrm{Pu}$ and $\mathrm{Np}$. There are 6 subdirectories, one for each element:

For Tc: Prodtc9

For I: ProdIf1

For Se: Prodse8

For U: Produo2

For Pu: Prodpu3

For Np: Prodnp4

Usually, one can tell the file contents by the file name. For example, produ01.H+ is the file contains the concentration data of $\mathrm{H}+$, in unit of mol/ kg solution. Those files with suffix of "(total)" are total concentration data for some components. Infiltration velocity is listed in the file *.Vx.

For solids, three types of data are presented. They are: (1) dissolution rates (denoted by "Dr" in the middle of its name), in unit of $\mathrm{m} / \mathrm{sec}$. The negative sign means the solid precipitates; (2) radii (denoted by "R", in unit of $m$; (3) volume fractions (denoted by "V"). Please note that initially the total volume fractions of solids $=1.0$ - porosity. The dissolution rate file of primary interest to you is the $* * *$.Dr.glass file as this contains the computed dissolution rate for LD6-5412 glass in space and time.

For the above mentioned files, the format is identical. At the beginning, there are several description lines starting with "\#". Each file has 461 data point (grids) and 23 values at different time steps. The first column is the $x$-coordinate of that data point, from 0-30 meters, followed by 23 values.

The time steps are listed in the file of *.tlist. The first column is time in seconds, the second one is in years.

* fl file contains release rate data as a function of time in units of mol/[sec.m**2]. The first column is time in years. The 2 nd and $3 \mathrm{rd}$ columns are the release rates at 20 and 23 meters, respectively.

The simulation results for $\mathrm{Np}$ are not accurate at this point. We are working to correct this.

Should there be any questions concerning the results, please let us know. Yueting chen can be reached at 375-6467. His e-mail address is d3j097eentropy.pnl.gov. 
WHC-SD-WM-RPT-225, Rev. 0

\section{APPENDIX C}

\section{COMPUTER MODEL FILE NAMING AND STORAGE}

All of the simulation cases with the unit cell model as described in this report were executed on UNIX-based workstations within the Westinghouse Hanford Company (WHC) Scientific and Engineering Computational Center (SECC) between November 1995 and July 1996. At a minimum, each simulation run requires/produces the files listed below, in addition to the PORFLOW executable file.

ACR. POR2394gr
fort. 15
fort. 16
fort. 35
ARCHIVE
RESTART
FLUXBAL
screen

PORFLOW initialization file ASCII input file Formatted report file ASCII water table release rate history file Binary archive/restart/plot output data file Binary restart input file ASCII flux balance output file PORFLOW SCREen output (redirected from UNIX standard output)

All of the files for a sensitivity case are stored in a directory. Directory names are of the form "sensam" or "sensbm" where the letter "b" indicates that the sensitivity case is identified in the base case specification (Mann et a1. 1995b), the letter "a" indicates an additional case, and the letter " $m$ " represents a sequence number ( 1 to 22 ). The base case directory name is nubasee (not sensb0), and is simply a product of naming directories from preliminary checkout cases. These directory names are shown in the second column ("Case Name") of Table 4 in the report.

Most of the simulations were executed on SECC machine ibm1, an IBM RISC System/6000 Model 580. Early in the work, backup copies of files were made in the Hanford Common File System (CFS). As the work progressed, the ability to use CFS degraded to the point where it could no longer be used for backups. Hence, wholesale remote copies ( $r c p$ ) were made on the /perm areas of SECC group machines erpagl and erpag2. These latter two machines are Silicon Graphics Indigos, and so the files indicated above as binary are generally unuseable in the Silicon Graphics environment. The original copies of some of the working files were lost in a disk crash on ibml. The end result is that some of the backups might be incomplete (particularly for the binary files). At a minimum, a second set of backups of the ASCII input files is also stored under the author's SECC home directory. 
WHC-SD-WM-RPT-225, Rev. 0

\section{APPENDIX D}

MODEL INPUT FOR SENSITIVITY CASE 22

Page

b22-1. inp

D-2

Tc. inp

D-6

Tc-nna.inp

D-8

TC-vol inp

D-10

Se. inp

D-12

b22-2. inp

D-14

U. inp

D-18

I. inp

D-20

Np. inp

D-22

Pu.inp

D-24 
WHC-SD-WM-RPT-225, Rev. 0

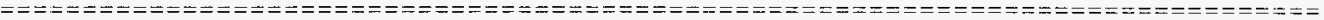

Jsername: nwk299

File Name: b22-1.inp

Job: b22-1.inp

Remote Printer Name: ascii

Host Name: sun2 
WHC-SD-WM-RPT-225, Rev. 0

TITLe Peformance Based on a Single Canister: Concept 1 Base Case

'

Units: length in meters (m)

mass in kilograms $(\mathrm{kg})$

time in years ( $y r)$

GRID $10 \times 44$

1

Coordinates in $\mathrm{x}$ direction: $\begin{array}{lllllllllll}-0.05 & 0.05 & 0.15 & 0.3 & 0.5 & 0.7 & 0.85 & 0.95 & 1.025 & 1.075\end{array}$ (

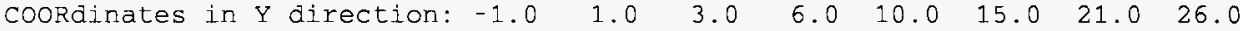

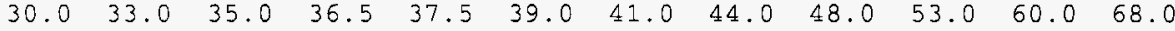

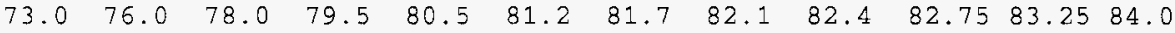

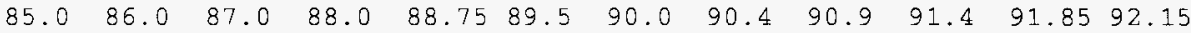

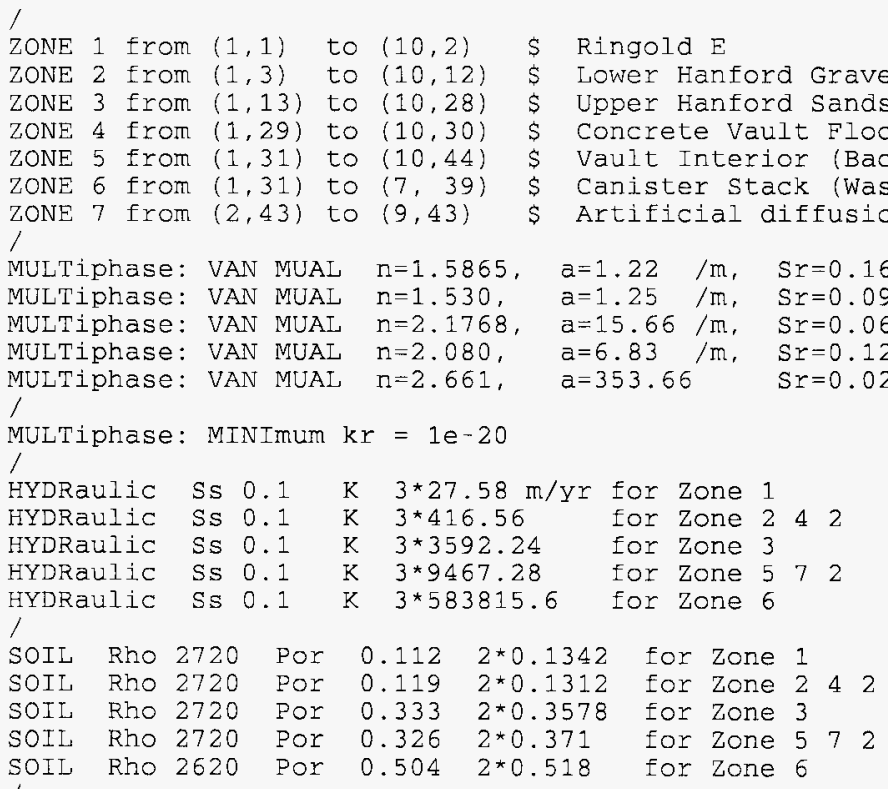

/

DATUM $0 \quad 0$

GRAVITY $0 \quad-1$

1

READ 22

$\mathrm{TIME}=0$

1

BOUN P - 1 GRAD $=0 \quad \$$ symmetry: center of canister

BOUN $\mathrm{P}+1$ GRAD $=0 \quad \$$ symetry: center of intercanister filler

BOUN $\mathrm{F}-2$ VALUe $=-1.0 \mathrm{~m} \quad \$$ water Table

BOUN P +2 FLUX $=-0.0005 \mathrm{~m} / \mathrm{yr} \$$ Assumed recharge of $0.5 \mathrm{~mm} / \mathrm{yr}$

I

PROPerties for P: GEOMetric mean at cell interfaces

MATRix sweeps in $X$ and $Y$ directions: $P=2$ iterations of $A D I$

METHod for nonlinearity of $P$ is PICArd

CoNvergence of P: LOCAL mode with epsilon=0.0005 and maxiter $=30$

1

/ Transport Properties: $\mathrm{C}=\mathrm{TC}: \quad \mathrm{Kd}=0$ 


$\begin{array}{llr} & & \begin{array}{c}C 2 \\ \mathrm{C}= \\ \mathrm{C} 4=\end{array} \\ \text { TRAN C } & \mathrm{Kd}=0.0 & \mathrm{Dm}=7.889 e-4 \\ \text { TRAN C } & \mathrm{Kd}=0.0 & \mathrm{Dm}=7.889 e-4 \\ \text { TRAN C2 } & \mathrm{Kd}=0.0 & \mathrm{Dm}=7.889 e-4 \\ \text { TRAN C2 } & \mathrm{Kd}=0.0 & \mathrm{Dm}=7.889 e-4 \\ \text { TRAN C3 } & \mathrm{Kd}=0.0 & \mathrm{Dm}=7.889 e-4 \\ \text { TRAN C3 } & \mathrm{Kd}=0.0 & \mathrm{Dm}=7.889 e-4 \\ \text { TRAN C4 } & \mathrm{Kd}=0.0 & \mathrm{Dm}=7.889 e-4 \\ \text { TRAN C4 } & \mathrm{Kd}=0.0 & \mathrm{Dm}=7.889 e-4\end{array}$

$\begin{array}{ll}\text { Tc-nna: } & \text { Kd }=0 \\ \text { Tc-v01: } & \mathrm{Kd}=0 \\ \text { Se: } & \mathrm{Kd}=0\end{array}$

/

/ Artificial diffusion barrier - next to top row of nodes

TRAN C $4 * 07$

TRAN C2 $4 * 07$

TRAN C $3 \quad 4 * 0 \quad 7$

TRAN C4 4 *0 7

$$
1
$$

INITial $\mathrm{C}=0$ everywhere

INITial $\mathrm{C} 2=0$ everywhere

INITial $C 3=0$ everywhere

INITial $C 4=0$ everywhere

PROPERTIES FOR C BY HARMOnIC PROPERTIES FOR C2 BY HARMONIC MEAN PROPERTIES FOR C 3 BY HARMONIC MEAN

PROPERTIES FOR CA BY HARMONIC MEAN 1

LOCATE SOURCE 1 at $(2,31)$ to $(7,39)$

LOCATE SOURCE 2 at $(2,31)$ to $(7,39)$

LOCATE SOURCE 3 at $(2,31)$ to $(7,39)$

LOCATE SOURCE 4 at $(2,31)$ to $(7,39)$

1

/ Fractional release rate: AREST output (moles/m**2/sec) in *. inp files. / Scale cards convert to fractional release rate (ppm/yr), , and also divide by the source volume $\left(0.9 \mathrm{~m} \times 7.2 \mathrm{~m} \times 1 \mathrm{~m}=6.48 \mathrm{~m}^{* * 2}\right)$. 1

SCALE $7.81 \in 6 \quad$ D-4

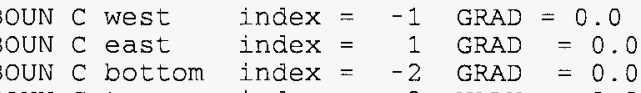$$
\text { I }
$$
BOUN C2 bottom B

BOUN C 3 west

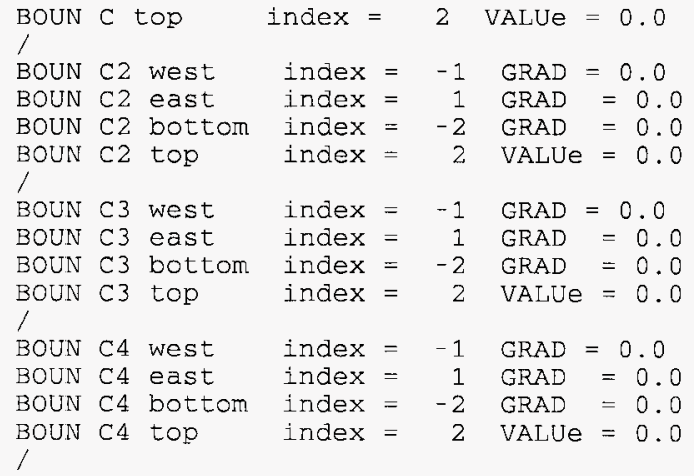

BOUN C 3 bottom

BOUN C3 top /

\section{BOUN C4 west}

BOUN C4 east

BOUN C4 bottom

$$
\text { B }
$$
for Zone 151
for Zone 6
for Zone 151
for Zone 6
for Zone 151
for Zone 6
for Zone 151
$\mathrm{aL}=8.225$
$\mathrm{a}=0.8225$
$\mathrm{a}^{\mathrm{T}}=0.8225$
$\mathrm{a} \mathrm{T}=0.8225$
$\mathrm{aT}=0.8225$ 
WHC-SD-WM-RPT-225, Rev. 0

SOUR 1 c Volumetric with 32 pairs in file 'TC.inp'

SCA-E $7.81 e 6$

SOUR 2 C2 VOLUmetric with 32 pairs in Eile 'Tc-nna.ing'

SCA:e 7.8106

SOUR 3 C3 VolUmetric with 32 pairs in file 'Tc-v01.inp'

SCA $=5.54$ e 8

SOUR 4 C4 VOLUmetric with 32 pairs in file 'Se.inp'

I

MATRIX for $\mathrm{C}=2$ using ADI

MATRIX for $\mathrm{C} 2=2$ using $\mathrm{ADI}$

MATRIX for $\mathrm{C} 3=1$ using $\mathrm{ADI}$

MATRIX for $\mathrm{C} 4=1$ using ADI

/

FLUX of $P$ from $(2,43)$ to $(9,43)$ every 200 steps

FLUX of $P$ from $(2,28)$ to $(9,28)$ every 200 steps

FLUX of $P$ from $(2,2)$ to $(9,2)$ every 200 steps

1

FLUX of $C$ from $(2,28)$ to $(9,28)$ every 100 steps

FLUX of C2 from $(2,28)$ to $(9,28)$ every 100 steps

FLUX of $C 3$ from $(2,28)$ to $(9,28)$ every 100 steps

FLUX of C4 from $(2,28)$ to $(9,28)$ every 100 steps

I

FLUX OF C FROM $(2,2)$ TO $(9,2)$ EVERY 100 STEPS

FLUX OF C2 FROM $(2,2)$ TO $(9,2)$ EVERY 100 STEPS

FLUX OF C3 FROM $(2,2)$ TO $(9,2)$ EVERY 100 STEPS

FLUX OF C4 FROM $(2,2)$ TO $(9,2)$ EVERY 100 STEPS

1

DIAGnostic node at $(5,33)$ every 50 steps $\$$ History node in the waste form WINDOW from $(1,1)$ to $(10,44)$

SAV $\Xi U, V, H, P, S, M O I S, C, C 2, C 3, C 4$ NOW $\$ I . C$.

1

SOLVE AUTO 100 YEARS, STEPS $=1 . e-5 \quad \mathrm{FAC}=1.02$ MAX $0.01 \quad 1 . e-93.05000000$

1

SOLVE AUTO 100 YEARS IN STEPS OF 1.e-4 FAC 1.02 MAX 0.05 1.e-8 3.0

sor

SOLVE AUTO 300 YEARS IN STEPS OF $1 . e-3$ FAC 1.02 MAX $0.11 . e-73.0$

/

SOLVE AUTO 500 YEARS IN STEPS OF $1 . e-6$ FAC 1.02 MAX $0.1 \quad 1 . e-123.0$

1

BOUN P +2 FLUX $=-0.003 \mathrm{~m} / \mathrm{Yr}$

1

SOLVE AUTO 500 YEARS IN STEPS OF $1 . e-6$ FAC 1.01 MAX $0.1 \quad 1 . e-153.0$

SOLVE AUTO 500 YEARS IN STEPS OF $1 . e-4$ FAC 1.02 MAX 0.2 1.e-15 3.0

SOLVE AUTO 500 YEARS IN STEPS OF $1 . e^{-3}$ FAC 1.02 MAX $0.4 \quad 1 . e-15 \quad 3.0$

SOLVE AUTO 500 YEARS IN STEPS OF 0.002 FAC 1.02 MAX $0.51 .0-15 \quad 3.0$

SOLVE AUTO 1000 YEARS IN STEPS OF 0.005 FAC 1.02 MAX $0.8 \quad 1 . e-15 \quad 3.0$

SOLVE AUTO 1000 YEARS IN STEPS OF 0.01 FAC 1.02 MAX $1.0 \quad 1 . e-15 \quad 3.0$

$/$

SOLVE AUTO 2000 YEARS IN STEPS OF 0.02 FAC 1.02 MAX 1.0

SOLVE AUTO 3000 YEARS IN STEPS OF $0.05 \quad 1.02 \quad 1.0$

1

SOLVE AUTO 5000 YEARS IN STEPS OF 0.1 FAC 1.02 MAX 2.0

SOLVE AUTO 5000 YEARS IN STEPS OF $0.2 \quad 1.02 \quad 2.0$

SOLVE AUTO 5000 YEARS IN STEPS OF 0.4 faC 1.02 max 2.

SOLVE AUTO 5000 YEARS IN STEPS OF 0.5 1.02 4.

SOLVE AUTO 70000 YEARS IN STEPS OF 0.5 fac $1.01 \max 5$.

1

END

QUIT 
WHC-SD-WM-RPT-225, Rev. 0

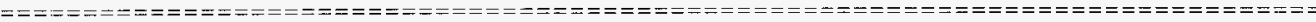
Jsername: nwk299

File Name: Tc.inp

Job: Tc.inp

Remote Printer Name: ascii

Host Name: sun2 


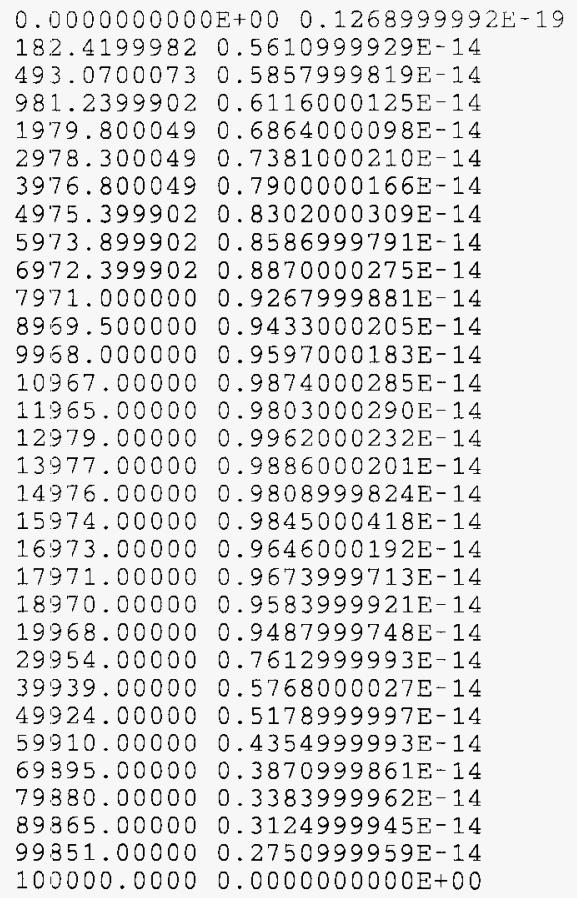


WHC-SD-WM-RPT-225, Rev . 0

Jsername: nwk299

File Name: Tc-nna.inp

Job: Tc-nna.inp

Remote Printer Name: ascii

Host Name: sun2 


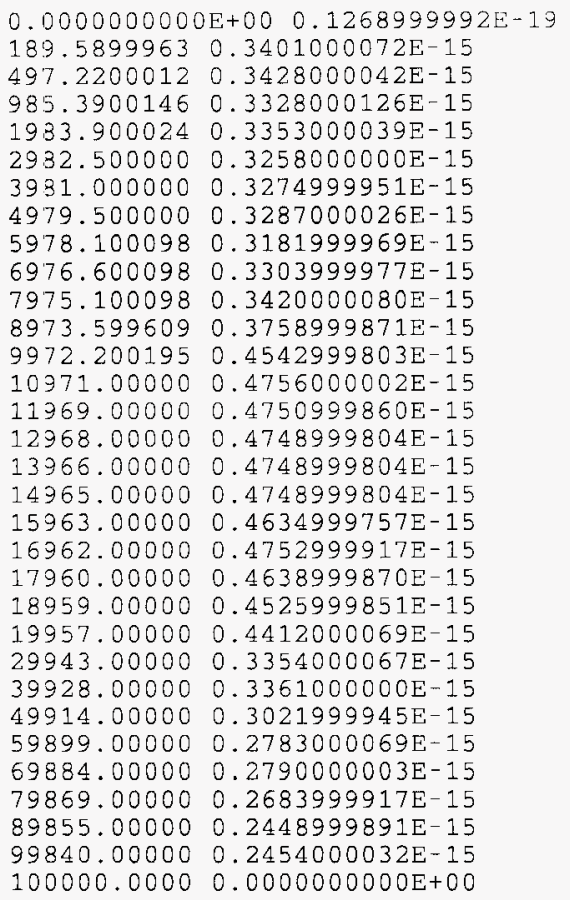


Username: nwk299

File Name: Tc-v01.inp

Job: Tc-v01.inp

Remote Printer Name: ascii

Host Name: sun2 


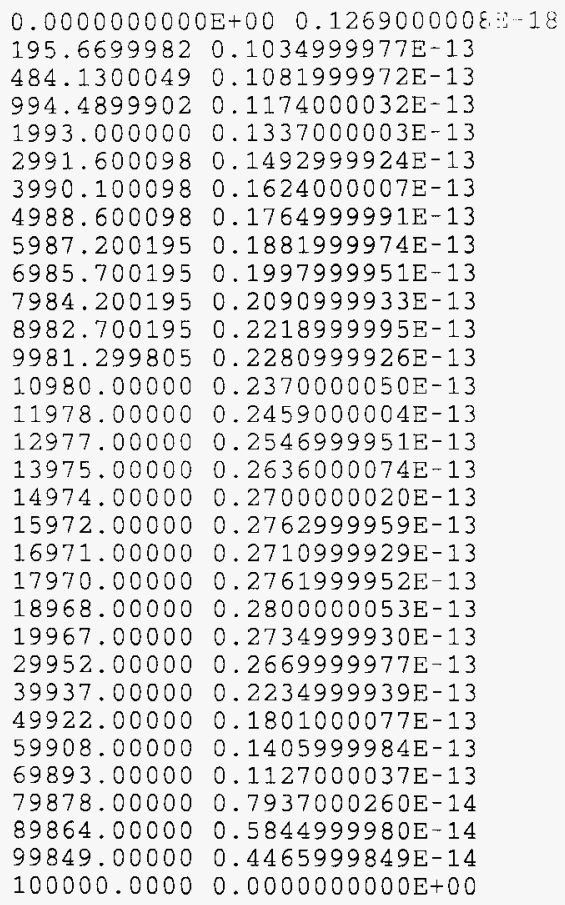


WHC-SD-WM-RPT-225, Rev. 0

Username: nwk299

File Name: Se.inp

Job: Se.inp

Remote Printer Name: ascii

Host Name: sun2 

$0.0000000000 \mathrm{E}+00 \quad 0.1268999992 \mathrm{E}-19$
$187.60000610 .1047000022 E-15$
$498.2500000 \quad 0.1108000026 \mathrm{E}-15$
$986.41998290 .1195000038 \mathrm{E}-15$
$1985.000000 \quad 0.1358000014 \mathrm{E}-15$
$2983.500000 \quad 0.1473999985 \mathrm{E}-15$
$3982.000000 \quad 0.1589999956 \mathrm{E}-15$
$4980.500000 \quad 0.1706000059 \mathrm{E}-15$
$5979.100098 \quad 0.1869000036 \mathrm{E}-15$
$6977.600098 \quad 0.1987999959 \mathrm{E}-15$
$7976.100098 \quad 0.2232999872 \mathrm{E}-15$
$8974.700195 \quad 0.2130000003 E-15$
$9973.200195 \quad 0.2141999946 \mathrm{E}-15$
$10972.00000 \quad 0.2149000011 \mathrm{E}-15$
$11970.00000 \quad 0.2156999973 E-15$
$12969.00000 \quad 0.2048999963 E-15$
$13967.00000 \quad 0.1939000030 \mathrm{E}-15$
$14966.00000 \quad 0.1944999935 \mathrm{E}-15$
$15964.00000 \quad 0.1952000000 E-15$
$16963.00000 \quad 0.1957000009 \mathrm{E}-15$
$17961.00000 \quad 0.1846000047 \mathrm{E}-15$
$18960.00000 \quad 0.1850000028 \mathrm{E}-15$
$19958.00000 \quad 0.1739000066 \mathrm{E}-15$
$29944.00000 \quad 0.1409000000 \mathrm{E}-15$
$39929.00000 \quad 0.1065000002 \mathrm{E}-15$
$49914.00000 \quad 0.9512000003 \mathrm{E}-16$
$59900.00000 \quad 0.8344999698 \mathrm{E}-16$
$69885.00000 \quad 0.7153999906 \mathrm{E}-16$
$79870.00000 \quad 0.7114999995 \mathrm{E}-16$
$89856.00000 \quad 0.5911000232 \mathrm{E}-16$
$99841.00000 \quad 0.5860000246 \mathrm{E}-16$
$100000.0000 \quad 0.0000000000 \mathrm{E}+00$ 
WHC-SD-WM-RPT-225, Rev. 0

Username: nwk299

File Name: b22-2.inp

Job: b22-2. inp

Remote Printer Name: ascii

Host Name: sun2 
TITLe Peformance Based on a single Canister: Concept I Base Case

/

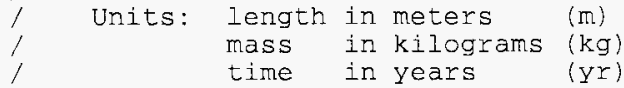

GRID $10 \times 44$

/

CooRdinates in $x$ direction: $\begin{array}{lllllllllllll}0.05 & 0.05 & 0.15 & 0.3 & 0.5 & 0.7 & 0.85 & 0.95 & 1.025 & 1.075\end{array}$

1

Coordinates in Y direction: $\begin{array}{lllllllll}-1.0 & 1.0 & 3.0 & 6.0 & 10.0 & 15.0 & 21.0 & 26.0\end{array}$

$\begin{array}{llllllllllll}30.0 & 33.0 & 35.0 & 36.5 & 37.5 & 39.0 & 41.0 & 44.0 & 48.0 & 53.0 & 60.0 & 68.0\end{array}$

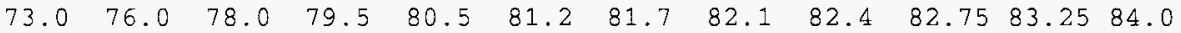

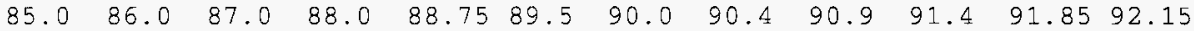

1

ZONE 1 from $(1,1)$ to $(10,2)$ \$ Ringold $\mathrm{E}$

ZONE 2 from $(1,3)$ to $(10,12)$ \$ Lower Hanford Gravels (Sandy gravel)

ZONE 3 from $(1,13)$ to $(10,28)$

ZONE 4 from $(1,29)$ to $(10,30)$

ZONE 5 from $(1,31)$ to $(10,44)$

ZONE 6 from $(1,31)$ to $(7,39)$

ZONE 7 from $(2,43)$ to $(9,43)$

/

MUTTiphase: VAN MUAL $n=1.5865$,

MULTiphase: VAN MUAL $n=1.530$,

MULTiphase: VAN MUAL $n=2.1768$,

MULTiphase: VAN NUAL $n=2.080$,

MULTiphase: VAN MUAL $n=2.661$,

$\$$ Upper Hanford Sands

$\$$ Concrete Vault Floor (Degraded at $t=0$ )

\$ Vault Interior (Backfill)

\$ Canister stack (Waste Form)

$\$$ Artificial diffusion barrier

I

MULTiphase: MINImum $\mathrm{kr}=1 \mathrm{e}-20$

/

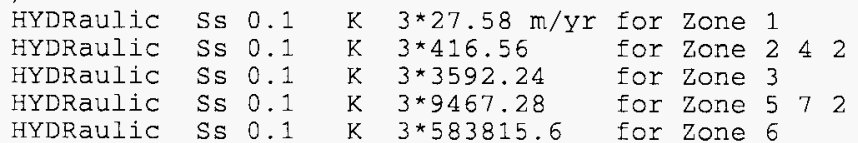

HYDRaulic Ss $0.1 \quad \mathrm{~K} \quad 3 * 583815.6$ for Zone 6

SOIL Rho 2720 Por $0.1122 * 0.1342$ for Zone 1

SOIL Rho 2720 Por $0.1192 * 0.1312$ for Zone 242

SOIL Rho 2720 Por $0.3332 * 0.3578$ for zone 3

SOIL Rho 2720 Por $0.326 \quad 2 * 0.371$ for Zone 572

SOIL Rho 2620 Por $0.5042 * 0.518$ for Zone 6

1

DATUM $0 \quad 0$

GRAVity $0 \quad-1$

I

READ 22

TIME $=0$

1

BOUN $P-1$ GRAD $=0$

$\begin{array}{lll}\text { BOUN } & \mathrm{P}+1 \text { GRAD }=0 & \$ \text { Symmetry: c } \\ \text { BOUN P }-2 \text { VALUe }=-1.0 \mathrm{~m} & \$ \text { water Table }\end{array}$

$\$$ Symmetry: center of canister

BOUN P +2 FLUX $=-0.0005 \mathrm{~m} / \mathrm{Yr} \quad \mathrm{s}$ Assumed recharge of $0.5 \mathrm{~mm} / \mathrm{Yr}$

$/$

PROPerties for P: GEOMetric mean at cell interfaces

MATRix sweeps in $X$ and $Y$ directions: $P=2$ iterations of $A D I$

METHod for nonlinearity of $P$ is PICArd

Convergence of P: LOCAI mode with epsilon=0.0005 and maxiter=30 /

/ Transport Properties: $\mathrm{C}=\mathrm{U} \mathrm{Kd}=0.6 \mathrm{ml} / \mathrm{gr}$ 


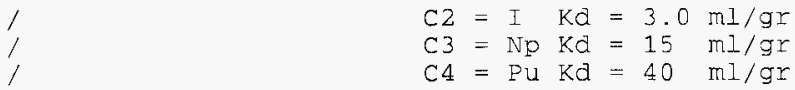

\begin{tabular}{|c|c|c|c|c|c|c|c|c|}
\hline TRAN & $\mathrm{C}$ & $\mathrm{Kd}=0.0006$ & $\mathrm{Dm}=7.889 e-4$ & $a L=8.225$ & $\mathrm{aT}=0.8225$ & for & Zone & 5 \\
\hline & C & $\mathrm{Kd}=0.0$ & $\mathrm{Dm}=7.889 e-4$ & $\mathrm{aL}=8.225$ & $\mathrm{aT}=0.8225$ & for & Zone & 6 \\
\hline AN & $\mathrm{C} 2$ & $\mathrm{Kd}=0.003$ & $D m=7.889 e-4$ & $a I=8.225$ & $\mathrm{aT}=0.8225$ & for & Zone & 5 \\
\hline RAN & $\mathrm{C} 2$ & $\mathrm{Kd}=0.0$ & $D_{n}=7.889 e-4$ & $a L=8.225$ & $\mathrm{aT}=0.8225$ & for & Zone & 6 \\
\hline $2 A N$ & C 3 & $\mathrm{Kd}=0.015$ & $\mathrm{Dm}=7.889 e^{-4}$ & $a L=8.22$ & $\mathrm{aT}=0.8225$ & for & Zone & 5 \\
\hline & C 3 & 0.0 & $\mathrm{Dm}=7.8$ & $a L=$ & $\mathrm{aT}=0.82$ & for & Zone & 6 \\
\hline & $\mathrm{C} 4$ & .04 & $\mathrm{Dm}=7.8$ & $\mathrm{aL}=8$ & $\mathrm{aT}=0$. & Eor & Zone & 1 \\
\hline & $\mathrm{C}_{4}$ & $\mathrm{Kd}=0.0$ & $\mathrm{Dm}=7.8$ & $\mathrm{a}^{\mathrm{L}}=8.2$ & $\mathrm{aT}=0.8$ & for & Zone & 6 \\
\hline
\end{tabular}
1

/ Artificial diffusion barrier

next to top row of nodes

/

TRAN C $4 * 0 \quad 7$

TRAN C2 $4{ }^{\star} 0 \quad 7$

TRAN C $34 * 0 \quad 7$

TRAN C4 $4 * 0 \quad 7$

/

INITial $\mathrm{C}=0$ everywhere

INITial $\mathrm{C} 2=0$ everywhere

INITial $\mathrm{C} 3=0$ everywhere

INITial $\mathrm{C} 4=0$ everywhere

/

\begin{tabular}{|c|c|c|c|c|c|c|c|}
\hline OUN & c & west & index & $=$ & -1 & $G R A D=$ & $=0.0$ \\
\hline BOUN & C & east & index & $=$ & 1 & GRAD & $=0.0$ \\
\hline OUN & C & bottom & index & $=$ & -2 & GRAD & $=0.0$ \\
\hline BOUN & C & top & index & $=$ & 2 & VALUE & $=0.0$ \\
\hline UNN & $\mathrm{C} 2$ & west & index & $=$ & -1 & GRAD & $=0.0$ \\
\hline UN & $\mathrm{C} 2$ & east & index & $=$ & 1 & GRAD & $=0.0$ \\
\hline OUN & $\mathrm{C} 2$ & bottom & index & $=$ & -2 & GRAD & $=0.0$ \\
\hline DUN & $\mathrm{C} 2$ & top & index & $=$ & 2 & VALUe & $=0.0$ \\
\hline DUN & $\mathrm{C} 3$ & west & index & $=$ & -1 & GRAD & $=0.0$ \\
\hline & $\mathrm{C} 3$ & east & index & $=$ & 1 & GRAD & $=0.0$ \\
\hline & c3 & bottom & index & $=$ & -2 & GRAD & $=0.0$ \\
\hline & C3 & top & index & $=$ & 2 & VALUe & $=0.0$ \\
\hline & C4 & west & & $=$ & -1 & GRAD & $=0.0$ \\
\hline & C4 & east & index & $=$ & 1 & GRAD & $=0.0$ \\
\hline & C4 & bottom & index & $=$ & -2 & GRAD & $=0.0$ \\
\hline & C4 & top & index & $=$ & 2 & VALUE & $=0.0$ \\
\hline
\end{tabular}

1

PROPERTIES FOR C BY HARMONIC MEAN

PROPERTIES FOR C2 BY HARMONIC MEAN

PROFERTIES FOR C 3 BY HARMONIC MEAN

PROPERTIES FOR C4 BY HARMONIC MEAN

1

LOCATE SOURCE 1 at $(2,31)$ to $(7,39)$

LOCATE SOURCE 2 at $(2,31)$ to $(7,39)$

LOCATE SOURCE 3 at $(2,31)$ to $(7,39)$

LOCATE SOURCE 4 at $(2,31)$ to $(7,39)$

/

/ Fractional release rate: AREST output (moles $/ \mathrm{m}^{\star} * 2 / \mathrm{sec}$ ) in *.f files.

/ SCALe cards convert to fractional release rate (ppm/yr),

/ and divide by source volume $\left(0.9 \mathrm{~m} \times 7.2 \mathrm{~m} \times 1 \mathrm{~m}=6.48 \mathrm{~m} *{ }^{\star} 2\right)$.

,

SCALe $4.63 e 5$ 
WHC-SD-WM-RPT-225, Rev. 0

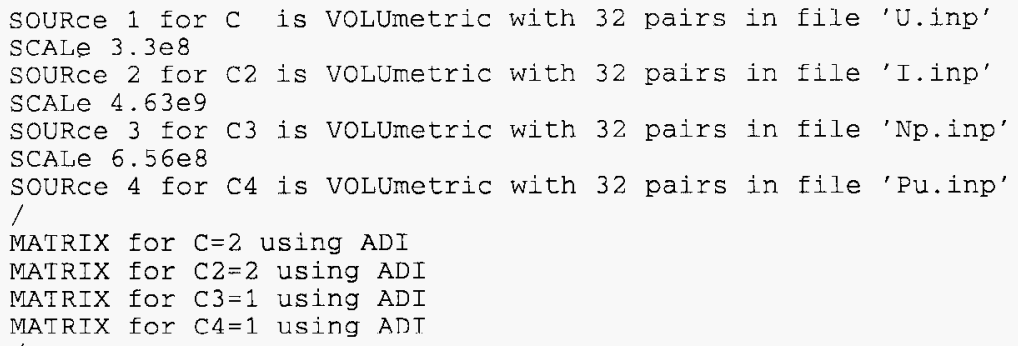


WHC-SD-WM-RPT-225, Rev, 0

Username: nwk299

File Name: U.inp

Job: U.inp

Remote Printer Name: ascii

Host Name: sun2 
$0.0000000000 \mathrm{E}+00 \quad 0.1269999960 \mathrm{E}-19$

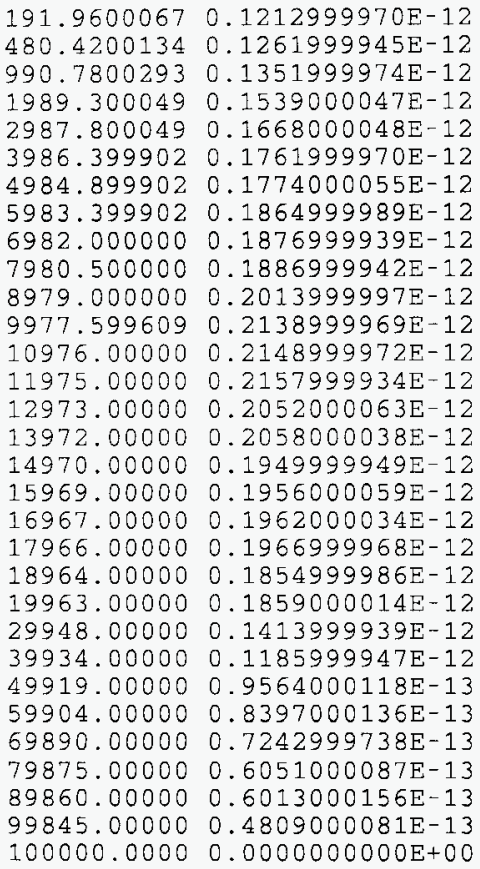


WHC-SD-WM-RPT-225, Rev. 0

Username: nwk299

File Name: I.inp

Job: I. inp

Remote Printer Name: ascii

Host Name: sun2 
$0.0000000000 \mathrm{E}+00 \quad 0.1268999992 \mathrm{E}-19$

$182.4199982 \quad 0.1317999942 \mathrm{E}-15$

$493.0700073 \quad 0.1379999974 \mathrm{E}-15$

$981.2399902 \quad 0.1454999977 \mathrm{E}-15$

$1979.8000490 .1618999982 \mathrm{E}-15$

$2978.300049 \quad 0.1747000027 \mathrm{E}-15$

$3976.8000490 .1852999980 \mathrm{E}-15$

$4975.399902 \quad 0.1982000054 \mathrm{E}-15$

$5973.899902 \quad 0.1995000025 \mathrm{E}-15$

$6972.399902 \quad 0.2122999938 \mathrm{E}-15$

$7971.000000 \quad 0.2133999984 \mathrm{E}-15$

$8969.500000 \quad 0.2261999897 \mathrm{E}-15$

$9968.000000 \quad 0.2273999972 \mathrm{E}-15$

$10967.00000 \quad 0.2399000065 \mathrm{E}-15$

$11965.00000 \quad 0.2295000036 \mathrm{E}-15$

$12964.00000 \quad 0.2419000101 \mathrm{E}-15$

$13962.00000 \quad 0.2314000044 \mathrm{E}-15$

$14961.00000 \quad 0.2323000034 \mathrm{E}-15$

$15959.00000 \quad 0.2332000024 \mathrm{E}-15$

$16958.00000 \quad 0.2339999985 \mathrm{E}-15$

$17956.00000 \quad 0.2345999890 \mathrm{E}-15$

$18955.00000 \quad 0.2352000060 \mathrm{E}-15$

$19953.00000 \quad 0.2242000126 \mathrm{E}-15$

$29939.00000 \quad 0.1800999966 \mathrm{E}-15$

$39924.00000 \quad 0.1339000006 \mathrm{E}-15$

$49909.00000 \quad 0.1105999970 \mathrm{E}-15$

$59894.00000 \quad 0.9867000114 \mathrm{E}-16$

$69880.00000 \quad 0.9804000053 \mathrm{E}-16$

$79865.00000 \quad 0.7445000060 \mathrm{E}-16$

$89850.00000 \quad 0.7382000000 \mathrm{E}-16$

$99836.00000 \quad 0.6152000296 \mathrm{E}-16$

$100000.0000 \quad 0.0000000000 \mathrm{E}+00$ 
WHC-SD-WM-RPT-225, Rev. 0

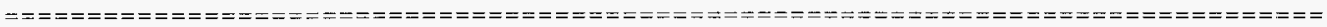

Username: nwk299

File Name: Np.inp

Job: Np.inp

Remote Printer Name: ascii

Host Name: sun2 
$0.0000000000 \mathrm{E}+00 \quad 0.1269000008 \mathrm{E}-18$

$197.25999450 .1305000030 \mathrm{E}-13$

$486.4200134 \quad 0.1442000070 \mathrm{E}-13$

$996.78002930 .1603000027 \mathrm{E}-13$

$1995.3000490 .1830999951 \mathrm{E}-13$

$2993.8000490 .1918000061 \mathrm{E}-13$

$3992.399902 \quad 0.1882999982 \mathrm{E}-13$

$4990.899902 \quad 0.1658999916 \mathrm{E}-13$

$5989.399902 \quad 0.1560000061 \mathrm{E}-13$

$6988.000000 \quad 0.1413000034 \mathrm{E}-13$

$7986.500000 \quad 0.1402999963 \mathrm{E}-13$

$8985.000000 \quad 0.1173000024 \mathrm{E}-13$

$9983.5996090 .1174000032 \mathrm{E}-13$

$10982.00000 \quad 0.1059999985 \mathrm{E}-13$

$11981.00000 \quad 0.1060999992 \mathrm{E}-13$

$12979.00000 \quad 0.1064000013 \mathrm{E}-13$

$13978.00000 \quad 0.9511999580 \mathrm{E}-14$

$14976.00000 \quad 0.8395999790 \mathrm{E}-14$

$15975.00000 \quad 0.7268000085 \mathrm{E}-14$

$16973.00000 \quad 0.8446999644 \mathrm{E}-14$

$17972.00000 \quad 0.7305999677 \mathrm{E}-14$

$18970.00000 \quad 0.7317999593 \mathrm{E}-14$

$19969.00000 \quad 0.6189999888 \mathrm{E}-14$

$29954.00000 \quad 0.5100000198 \mathrm{E}-14$

$39939.00000 \quad 0.5124999952 \mathrm{E}-14$

$49925.00000 \quad 0.3957999886 \mathrm{E}-14$

$59910.00000 \quad 0.3971000147 \mathrm{E}-14$

$69895.00000 \quad 0.2816999919 \mathrm{E}-14$

$79881.00000 \quad 0.2816999919 \mathrm{E}-14$

$89866.00000 \quad 0.2791999953 \mathrm{E}-14$

$99851.00000 \quad 0.2766999988 \mathrm{E}-14$

$100000.0000 \quad 0.0000000000 \mathrm{E}+00$ 
WHC-SD-WM-RPT-225, Rev. 0

Username: nwk299

File Name: Pu.inp

Job: Pu.inp

Remote Printer Name: ascii

Host Name: sun2 


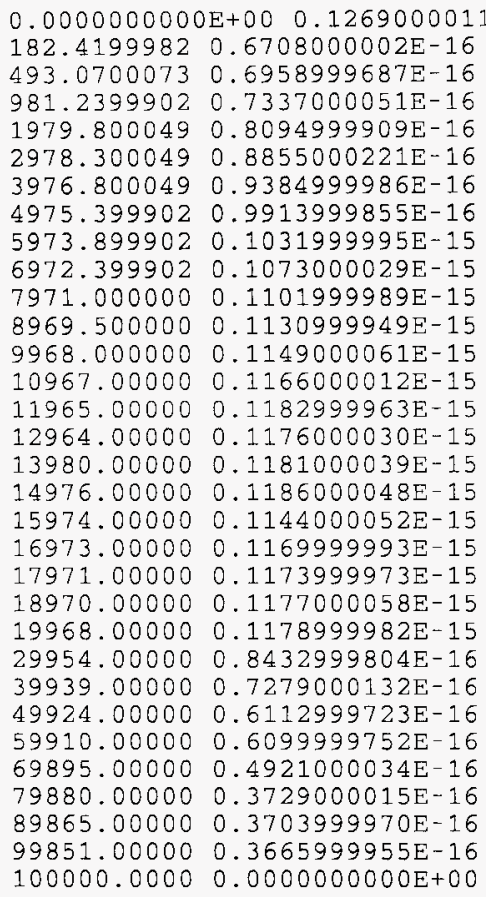




\section{DISTRIBUTION SHEET}

\begin{tabular}{|c|c|c|c|c|c|}
\hline \multirow{2}{*}{$\begin{array}{l}\text { To } \\
\text { Distribution }\end{array}$} & \multirow{2}{*}{\multicolumn{3}{|c|}{$\begin{array}{l}\text { From } \\
\text { N. W. Kline }\end{array}$}} & \multicolumn{2}{|l|}{ Page 1 of 1} \\
\hline & & & & \multicolumn{2}{|l|}{ Date $9-6-96$} \\
\hline \multicolumn{4}{|l|}{ Project Title/Work Order } & \multicolumn{2}{|c|}{ EDT No. 618552} \\
\hline \multicolumn{4}{|c|}{$\begin{array}{l}\text { Unit Cell Modeling in Support of Interim Performance Assessment } \\
\text { of Low Level Tank Waste Disposal/D4DC1 }\end{array}$} & \multicolumn{2}{|l|}{ ECN No. $\quad N / A$} \\
\hline Name & MSIN & $\begin{array}{c}\text { Text } \\
\text { With All } \\
\text { Attach. }\end{array}$ & Text Only & $\begin{array}{l}\text { Attach./ } \\
\text { Appendix } \\
\text { Only }\end{array}$ & $\begin{array}{l}\mathrm{EDT} / \mathrm{ECN} \\
\text { Only }\end{array}$ \\
\hline
\end{tabular}

N. R. Brown

$Y$. Chen

C. W. Denslow

K. R. Fecht

E. A. Fredenberg

E. J. Freeman

J. S. Garfield

K. A. Gasper

V. G. Johnson

R. Khaleel

C. T. Kincaid

N. W. Kline $(10)$

A. J. Knepp

P. E. Lamont

D. W. Langford

A. H. Lu

F. K. Mangan

F. M. Mann

B. P. McGrail

T. R. Neville

R. J. Puigh

S. P. Reidel

P. D. Rittmann

F. A. Schmittroth

L. C. Swanson

K. M. Thompson

R. D. VanHouten

D. E. Wood

M. I. Wood

G. F. Williamson

Document Contro]

Central Files

Amtec Engineering, Inc.

P. 0. Box 3633

Bellevue, WA 98009-3633

J. M. Werner

K6-51 $x$

K2-40 $\quad x$

H9-02 $x$

HO-02 $X$

H5-61 $x$

HO-31

H5-49

G3-21

H6-06

HO-31

K9-33

$\mathrm{H} 0-31$

$\mathrm{H} 4-80$

S7-53

B1-11

H0-31

H8-22

HO-31

K2-44

H5-24

$\mathrm{HO}-31$

H6-06

HO-31

HO-35

H9-11

HO-12

H8-44

H6-30

T3-01

H5-03

K5-51

A3-88

$x$
$x$
$x$
$x$
$x$
$x$
$x$
$x$
$x$
$x$
$x$
$x$
$x$
$x$
$x$
$x$
$x$
$x$
$x$
$x$
$x$
$x$
$x$
$x$
$x$
$x$
$x$
$x$
$x$
$x$
$x$
$x$
Daniel B. Stephens \& Associates, Inc.

1845 Terminal Drive

Richland, WA 99352

M. G. Peipho

Analytic and Computational Research, Inc. 1931 Stradella Road

Bel Air, CA 90077

A. K. Runchal 